\title{
Quintais de Olinda - uma leitura indiciária sobre sua gênese
}

\begin{abstract}
Juliana Coelho Loureiro ${ }^{1}$
RESUMO: Este artigo tem como objetivo refletir, a partir dos vestígios documentais e permanências do sítio histórico, sobre a formação dos quintais na Vila de Olinda, nordeste do Brasil. Fundada em meados do século XVI, tornou-se uma das principais vilas do império português, tendo sido bastante referenciada pelos relatos da época e representada na iconografia dos séculos XVI e XVII. A riqueza por ela representada motiva a invasão da Companhia das Índias Ocidentais, em 1630, que, pela dificuldade em dominar seu espaço urbano, transfere o núcleo administrativo para a região do porto: o Recife. A mudança coloca Olinda numa situação marginal, o que, dentre outros efeitos, permitiu ao espaço urbano manter até os dias atuais suas feições originais. Tal legado fez com que a cidade alcançasse o título de Patrimônio Mundial da Humanidade pela Unesco. Embora os quintais constituam parte expressiva do sítio histórico e, portanto, parte considerável desse patrimônio, eles acabam por receber um tratamento diferenciado com relação aos edifícios. Pouca atenção tem sido dirigida ao tema por parte daqueles que investigam o urbanismo no Brasil. E é em resposta a esta lacuna que esta investigação se coloca como um passo inicial aos estudos referentes à formação dos quintais de Olinda, ciente, acima de tudo, da sua incapacidade de esgotar as inúmeras interrogações decorrentes do processo investigativo. As principais fontes de pesquisa utilizadas foram a cartografia histórica, os relatos de época e as permanências do sítio histórico.
\end{abstract}

PALAVRAS-CHAVE: Quintal. Patrimônio. Urbanismo. Olinda.

ABSTRACT: This article aims to reflect, from the documentary evidence of the historical and stay on the formation of the gardens (backyard) in the village of Olinda, northeastern Brazil. Founded in the mid sixteenth century, the village became one of the main towns of the Portuguese Empire, being quite the referenced reports at the time and represented in the iconography of the sixteenth and seventeenth centuries. The wealth that represented the town encourages the invasion of the West India Company in 1630, that the difficulty of mastering your urban space, transferring the administrative core for the region of the port: Recife. This change puts a marginal situation Olinda, which among other effects, allowed the urban space maintained to this day its original features. This legacy has made the city achieving the title of
1. Docente da Universidade Federal de Alagoas, doutoranda do Programa de Pósgraduação em Urbanismo - PROURB/UFRJ. E-mail: $<$ julianacloureiro@yahoo. com.br>. 
World Heritage by Unesco. Although the gardens constitute a significant part of the historical and, therefore, a considerable part of that heritage, they end up receiving a different treatment with respect to buildings. Little attention has been directed to the subject by those who investigate the urban planning in Brazil. And it is in response to this gap that this research stands as an initial step to studies on the formation of the backyards of Olinda, knowing, above all, their failure to exhaust the numerous questions arising from the investigative process. The main research sources were used to historical cartography, reports of time and permanence of the historic site.

KEYWORDS: Backyard. Heritage. Urbanism. Olinda.

Os quintais são áreas urbanas que, nos dias atuais, nos remetem a uma atmosfera de desafio, experimentação e descobertas; e, talvez por este motivo, tão presentes nas histórias infantis. Algumas vezes, são espaços de limites frouxos, de composição variada e mutante, onde, para formação de sua ambiência, contribuem reciprocamente o homem e a natureza (Figura 1). Sua arquitetura irregular desafia a racionalidade humana, propondo continuamente uma nova perspectiva. Esse movimento incessante, sentido por seus fluxos, ciclos e velocidades, fornecem os parâmetros da relação do homem com o tempo e o espaço. Nos quintais de Olinda, o tempo recua ao início de nossa história.

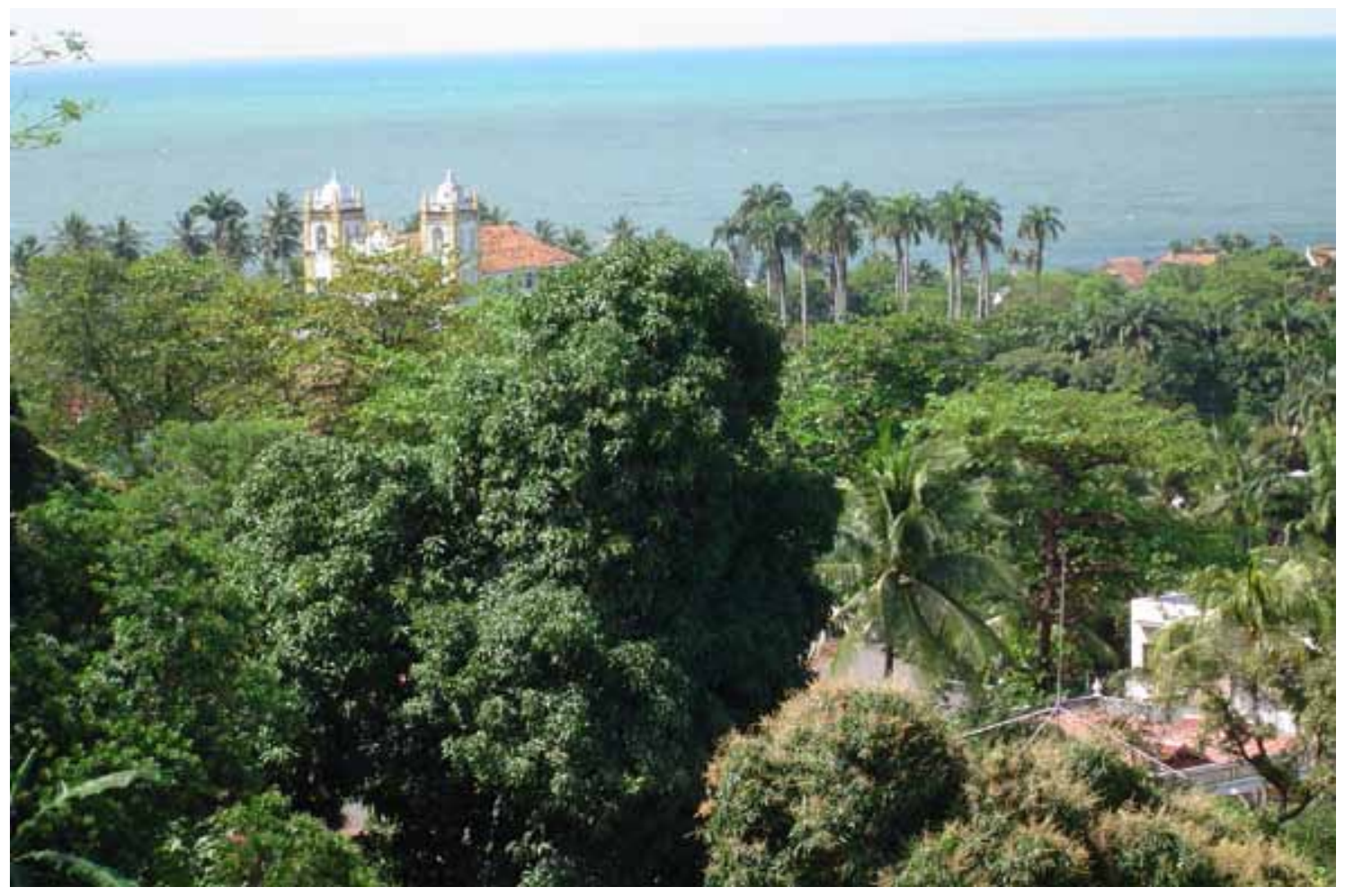

Figura 1 - Vista do alto de Olinda a partir dos quintais, 2004. Fonte: arquivo pessoal da autora 
Olinda faz parte de um grupo de cidades brasileiras que surgiram no início da colonização portuguesa no Novo Mundo. Fundada no dia 12 de março de 1537, foi o centro da capitania de Pernambuco e, pelo notável desenvolvimento, tornou-se uma das principais vilas do Império Português.

Pelo seu valioso acervo arquitetônico e urbanístico, Olinda alcançou o estatuto de Monumento Nacional, com a Lei Federal n. ${ }^{\circ} 6863$ de 26 de novembro de 1980. Em 1982, foi tombada pela Unesco e, consequentemente, passou a constituir Patrimônio Cultural da Humanidade. Nesse mesmo ano, foi concedido à cidade, pelo valor de suas áreas verdes, o título de Cidade Ecológica (Decreto Municipal n. ${ }^{\circ} 23$, de 29 de junhol.

sítio histórico é, atualmente, área protegida e de interesse público. Seu território tem 1,89 km² definido como Zonas Especiais de Proteção Cultural e Urbanística - ZEPEC 1 (área de tombamento) e 7,84 km² de área de preservação ao entorno do sítio histórico, compreendendo a área da antiga vila de Olinda ${ }^{2}$. Sua paisagem é caracterizada pelo grande número de edifícios históricos que pontuam o espaço público, emoldurados pela significativa massa vegetal. Esta, em sua grande maioria, oriunda dos quintais e cercas conventuais que ainda compreendem boa parte do território da cidade, como é possível constatar pela experiência urbana. Apesar de fazerem parte do polígono de tombamento, muitas vezes, não são compreendidos pela população como espaços patrimoniais, suportes da memória coletiva.

A importância patrimonial dos quintais também não parece encontrar repercussão nos estudos sobre a história das cidades brasileiras. Até o momento, não foi identificada nenhuma bibliografia que tratasse a formação desses espaços urbanos, o que causa obstáculo à pesquisa e, como estudo inaugural, em grande esforço para construir o objeto de estudo. De modo um pouco mais amplo, ainda há muito para investigar sobre a vida privada no Brasil.

Portanto, é necessário investigar os quintais por seus vestígios, buscando - através de uma leitura indiciária das fontes documentais e das permanências no sítio - reconstituir sua espacialidade original. Partiremos de um "paradigma indiciário", uma vez que não podemos acessar diretamente o objeto de pesquisa; e é desta forma que ele tem se apresentado, por indícios.

Tal caminho foi tratado em um artigo seminal escrito por Carlo Ginzburg. Este historiador vai mostrar que a busca do conhecimento através dos sinais tem origem muito antiga. "Por milênios o homem foi caçador. Durante inúmeras perseguições, ele aprendeu a reconstituir as formas e movimentos das presas invisíveis pelas pegadas na lama, ramos quebrados" 3 . $\bigcirc$ artigo prossegue mostrando a longevidade desta forma de conhecimento, que na modernidade será absorvida por diversos campos do saber, como a psicanálise, por exemplo. Neste sentido, seguindo os rastros legados pelos portugueses e holandeses, faremos uma pequena incursão no universo da representação.

Este artigo é parte de uma investigação que tinha como objetivo entender a formação do quintal enquanto espaço urbano ${ }^{4}$. Junta-se a outros esforços de pesquisa que investigam a estruturação inicial da vila de Olinda,
2. Site oficial da Prefeitura Municipal de Olinda.Acessado 28.06 .2012

3. Cf. Carlo Ginzburg (1990, p. 151).

4. Este trabalho é resultado da dissertação de mestrado em Dinâmicas do Espaço Habitado, orientada pela profa. Dra. Maria Angélica da Silva, defendida em 2008 na Universidade Federal de Alagoas e teve apoio da Fundação de Amparo à Pesquisa do Estado de Alagoas - FAPEAL. 
5. Com destaque ao trabalho realizado pela arquiteta $\mathrm{Va}$ léria Agra, que produziu um estudo detalhado e comparativo da Carta Foral.

6. Cf.José Luís Mota Menezes (1998, p. 333).

7.A Prefeitura Municipal de Olinda, com o intuito de reaver a cobrança do foro das áreas pertencentes ao município, iniciou uma investigação histórica para determinar o território de Olinda a partir de sua demarcação mais antiga. Baseou-se então no legado de Duarte Coelho, a Carta Foral de Olinda, que marcou o nascimento da vila bem como as áreas que ela abrangia. A equipe, dirigida pela arquiteta Valéria Agra fez as transcrições paleográ ficas do livro de Tombo $\mathrm{n}^{\circ}$ 01-B de 1783-1806. Este livro tem, entre outros dados importantes, a cópia do Foral de 1783 , sua confirmação e Ação Demarcatória feita pelo juiz do Tombo, José Ignácio Arouche, em 1710. Para esse empreendimento, também foi importante a reconstituição textual do Foral - $\mathrm{O}$ chamado Foral de Olinda de 1537 - feita por Antônio Gonsalves Mello; cf. PROJETO Foral (2000, p. 16-17).

8. Ibidem.. A Carta Foral é resultado de reconstituição textual produzida pelo historiador José Antônio Gonsalves de Mello, baseado em 7 cópias: 1. Cópia datada de 1675, existente no Arquivo Histórico Ultramarino (AHU-Lisboa), Pernambuco, papéis avulsos, caixa $6 ; 2$. Cópia de 1723, no mesmo AHU, Per nambuco, papéis avulsos caixa 39; 3. Cópia de 1783, existente na Prefeitura de Olinda, no Livro de Tombo dos bens pertencentes à Câmara Municipal; 4. Cópia de 1822 , conservada na mesma Prefeitura, no livro intitulado Foral, texto de que se serviu Pereira da Costa para publicação em seus Anais Pernambucanos; 5. Cópia de 1842, guardada no mosteiro de São Bento de Olinda como os que foram realizados pela Secretaria do Patrimônio, Ciência e Cultura de Olinda ${ }^{5}$. Tem o intuito de trazer contribuições sobre o papel dessas áreas não edificadas que, chegando aos dias de hoje, são fundamentais para manter a feição patrimonial de Olinda, e, portanto, o seu tífulo junto à Unesco.

Inicialmente trataremos o modo como a vila foi concebida, sua configuração no território e seus critérios de apropriação. Para isto, é feita uma breve análise do documento compreendido como sua certidão de nascimento, sua Carta Foral. E assim, seguimos com um olhar mais ampliado, investigando a formação urbana, aproximando-nos em seguida à escala da quadra, onde analisaremos sua morfologia e composição. Em seguida, iremos nos deter na constituição do lote e, finalmente, na do quintal.

\section{A construção do espaço urbano}

A formação do espaço urbano de Olinda inicia-se no processo de escolha do sítio para a vila e, a partir deste momento, poderemos observar a consideração de uma série de critérios, demonstrando claramente haver racionalidade em tal decisão. Esta racionalidade também é percebida na concepção de suas partes.

Duarte Coelho, primeiro donatário da capitania de Pernambuco, chega às terras do Novo Mundo no dia 9 de março de 1535. Desembarca em área próxima à ilha de ltamaracá, buscando uma antiga feitoria, depois chamada "dos Marcos", onde toma posse da capitaniab. Acreditando que o lugar era inseguro, o donatário parte para o sul a busca de um local mais adequado, que mais tarde, resultaria na vila de Olinda.

A fundação da vila se dá através do documento que transfere a posse do território à câmara da vila e ao povo, a Carta Foral. A doação feita pelo donatário data de 12 de março de 1537, quando se comemora o nascimento da Vila.

Tradicionalmente, o foral era um documento que regulava a administração, as relações sociais e os direitos e encargos dos moradores, instrumento que baseava a instituição do Concelho ${ }^{7}$. Embora as cidades portuguesas tivessem foral, o de Olinda é bem diferente. Não contêm as diretrizes fiscais, normas judiciais ou penais, nem os limites do termo, é uma carta de doação dos bens destinados ao patrimônio público da câmara, além de conferir o tífulo de vila ao povoado e instituir patrimônio para o concelho.

Para a análise deste documento, utilizamos a reconstituição produzida por José Antônio Gonsalves de Mello ${ }^{8}$, em que se lê:

No ano de 1537 deu e doou o senhor governador a esta sua Vila de Olinda, para seu serviço e de todo o seu povo, moradores e povoadores, as cousas seguintes:

Os assentos deste monte e fraldas dele, para casaria e vivendas dos ditos moradores e po- 
voadores, os quais thes dá livres, forros e isentos de todo o direito para sempre, e às várzeas das vacas e a de Beberibe e as que vão pelo caminho que vai para o passo do Governador e isto para os que não têm onde pastem os seus gados e isto será nas campinas para passigo, e as reboleiras de matos para roças a quem o concelho as arrendar, que estão das campinas para o alagadiço e para os mangues, com que confinam as terras dadas a Rodrigo Álvares e outras pessoas.

Percebe-se, no texto, uma nítida preocupação com o tipo de ocupação do solo da Vila, estabelecendo lugares diferenciados para determinados equipamentos. Esta "setorização" delimita: "Os assentos deste monte e fraldas dele para casarias e vivendas dos ditos moradores e povoadores", estipulando dessa forma a situação das habitações. Mais adiante, indica lugar para o pasto de gado: "as várzeas das vacas e a de Beberibe e as que vão pelo caminho que vai para o passo do Governador e isto para os que não têm onde pastem seus gados e isto será nas campinas para passigo", que antecipa inclusive uma possível decisão da câmara para este tipo de produção.

A Carta Foral estabelece na vila uma espécie de zoneamento, especificando as terras doadas e sua situação, e relata especialmente o patrimônio da câmara. Este zoneamento chega à minúcia de prever a rua de serventia para o povo da Vila: " ha de ir uma rua de serventia ao longo do dito rio novo para serventia do povo, de que se possa servir de carros, que será de cinco ou seis braças de largo e rodeará pelo pé do montinho até o varadouro da galeota"10, definindo, deste modo, fluxos e conexões.

Neste momento, é relevante observar como o donatário estabelece o diálogo contínuo entre o espaço urbano e as características do lugar, sua natureza. Os elementos da geografia são partes constituintes de suas determinações, por exemplo, ao citar "montinho", "os assentos do monte e fraldas dele" e "do ribeiro a lombada do monte".

Preocupações com o fornecimento de lenha e madeira para a Vila fazem parte do documento. Na Carta Foral lê-se: "Todos os mangues ao redor desta Vila, que estão ao longo do rio Beberibe, assim para baixo como para cima, até onde tiver terra de arvoredo e roças ou fazendas pelo Senhor Governador, todos os ditos mangues serão para serviço da dita Vila e povo. E assim os rios dos Cedros e itha e porto dos navios" ${ }^{11}$. $\bigcirc$ mangue, enquanto vegetação nativa, passa a fazer parte do texto do Foral.

Olinda, portanto, não parece se conformar sobre suas colinas, mas a partir delas (Figura 2). As definições de Duarte Coelho visam promover o melhor desenvolvimento da Vila e seu uso por parte dos moradores, distinguindo zonas de interesse comum e particular, como por exemplo, o local para cultivo de roças, o fornecimento de água, madeira e lenha. $\bigcirc$ que de certa forma confirma a teoria de Nestor Goulart quando diz que, a ordem que norteava as cidades coloniais portuguesas foi "necessariamente elaborada na prática"12. códice Monte Documento 1766-1876, p. 1-4; 6. Cópia do Instituto Arqueológico Pernambucano, ca. 1876,"; 7. Cópia de 1805, existente no Arquivo Público Estadual Pernambucano, Livro de ordens Régias 1534-1824, p. 62-64.

9.A rua de serventia prevista por Duarte Coelho no Foral deveria medir entre $11 \mathrm{~m} \mathrm{e}$ 13,2 m de largura.

10. Cf. PROJETO Foral (2000, p.16-17); grifo nosso.

11. Ibidem.

12. Cf. Nestor G. Reis Filho (1968, p. 15). 


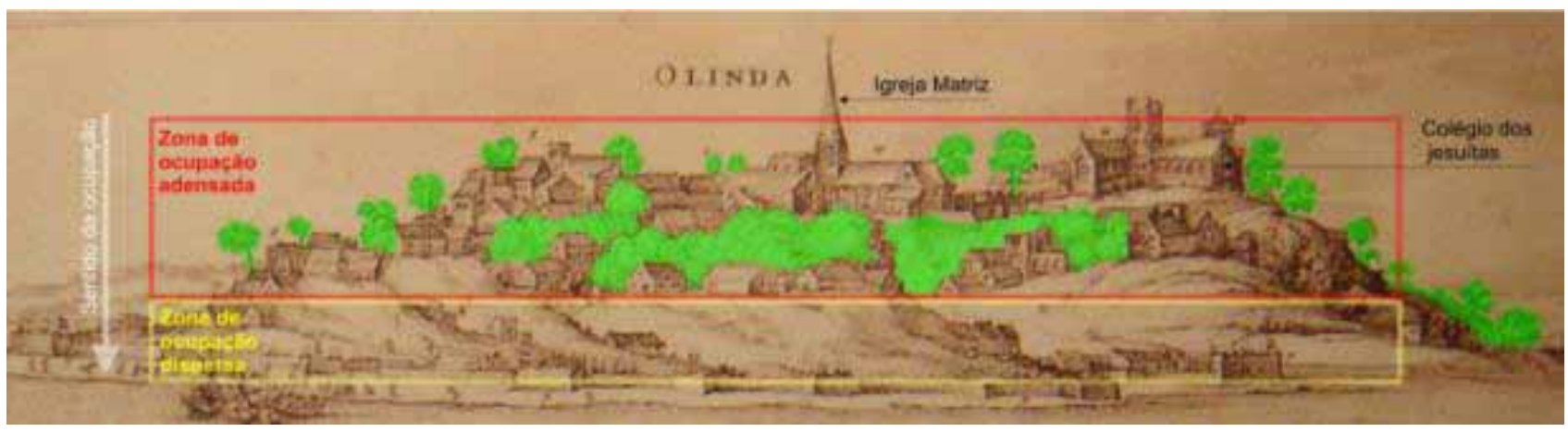

Figura 2 - Identificação das massas vegetais. Infográfico elaborado pela autora, utilizando detalhe de mapa existente em Claes Jansz[oon] Visscher, De Stadt Olinda de Pharnambuco..., 1630. Fonte do mapa: Biblioteca Nacional, Rio de Janeiro.

13. Cf. José Luís Mota Menezes (1998, p. 336).
Assim sua conformação demonstra ser resultado de uma racionalidade própria, gerada a partir da tradição lusitana, da experiência ultramarina e sua capacidade de assimilar elementos vernáculos dos lugares conquistados.

A própria escolha do sítio para a vila parece estar balizada por uma série de critérios, como por exemplo, as condições de defesa da vila, a comunicação com a metrópole e a ligação com o interior do território (engenhos), através do sistema marítimo e fluvial. Deste modo, garantiriam o domínio das terras, circulação e escoamento de mercadorias. José Luis da Mota Menezes comenta:

Não parece obra do acaso tais formas de escolha [do sítio]. Elas foram fruto de um hábito que espelhava ainda uma tradição que vinha desde as cidades medievais. Talvez a Memória Urbana tenha se aliado à racionalidade, decorrente dos princípios defensivos que se encontravam presentes na Arte da Defesa das Praças, e estes falaram mais alto. Isto não querendo dizer que tal escolha, pela altura dos sítios, nos leve de pronto a afirmativa de que esses desenhos urbanos, às vezes por suas irregularidades nos traçados das ruas, sejam medievais ${ }^{13}$.

O autor confirma as intenções de defesa, porém destaca que essa atitude é consequência de uma nova forma de pensar, indicando que as ações do donatário representavam uma racionalidade particular e uma estratégia para o futuro, distinguindo-se, deste modo, das cidades medievais. Estas, por exemplo, aumentavam sucessivamente os muros da cidade à medida que fossem crescendo, não tendo a priori um planejamento de expansão.

A vila se desenha a partir de princípios racionais de apropriação do solo. Questões relativas à defesa, subsistência, moradia, crença estão dentro de uma codificação própria da experiência urbana lusitana, presente desde o primeiro momento.

A Carta Foral, elaborada pelo donatário, registra as determinações urbanísticas da vila, estabelecendo espaços para determinados fins, a partir de um planejamento prévio. Embora seu pensamento não esteja representado por 
uma planta, é facilmente identificável pelos pontos de referência no território. Estes participam não apenas como suporte, mas como coadjuvantes do processo de concepção urbana. A proposta da carta de Olinda parece possuir características modernas, principalmente quando expressa preocupações com necessidades futuras. $\bigcirc$ grau de abstração na concepção de Olinda nos indica uma lógica diferenciada na construção urbana.

traçado urbano a partir da iconografia do século XVII

A produção iconográfica sobre a Vila constitui fonte importante para o estudo do espaço urbano de Olinda e, consequentemente, dos seus quintais. Faremos uma análise comparativa entre o discurso textual e iconográfico dos séculos XVI e XVII, buscando, a partir destas representações, tecer considerações acerca de seu possível desenho original. Desse modo, teremos subsídios para aferir a formação urbana do sítio, bem como de seus componentes: os quintais.

A Companhia das Índias Ocidentais, que invadiu Pernambuco em 1630 e aí permaneceu até 1654, foi responsável por importante levantamento cartográfico e natural do Nordeste brasileiro. Foi produzido extenso levantamento do território, que superou a produção portuguesa pela quantidade e qualidade das obras.

Embora tenham sido reunidos vinte e um registros iconográficos sobre a Vila 15 mapas portugueses e 5 holandeses, 3 plantas holandesas, 4 gravuras, 4 pinturas), neste artigo focamos em apenas algumas imagens. Inicialmente nos detivemos especificamente na imagem denominada Mapa de Olinda (Figura 3), por conter informações importantes sobre o desenho urbano - em especial o parcelamento do solo - e, mais especificamente, sobre as áreas não edificadas dentro da urbe. Na verdade, é o único que mostra os quintais em um surpreendente grau de detalhamento.

Sobre a origem dessa imagem, José Antônio Gonsalves Mello localiza uma carta do Coronel Waerdenburch, datada de 3 de abril de 1630, endereçada ao órgão de direção da Companhia das Índias Ocidentais, o Conselho dos XIX, onde constava o seguinte trecho: "com esta vai uma planta [plaan] desta cidade [de Olinda], o melhor que o conseguiu fazer um pintor [schilder]; a do engenheiro Commersteijn ainda estar por concluir e será enviada na primeira oportunidade" 14. Ou seja, a imagem seria uma prévia do que estava sendo feito pelo engenheiro ${ }^{15}$. No entanto não é a primeira planta da cidade, pois Matias de Albuquerque já havia determinado um levantamento, em 1629, pelo engenheiro Cristóvão Álvares para a fortificação da dita praça ${ }^{16}$.

- Mapa de Olinda pertence ao Arquivo Nacional da Holanda.

inventário indica ser a obra de autoria de Johannes Vingboons, incluída em seu Atlas, datada de aproximadamente 1665. Sabe-se, no entanto, que tal data não corresponde aos desenhos feitos in loco. Estes devem ser contemporâneos à
14. Diederik Waerdenburch, apud Antônio Gonsalves de Mello (1976, p. 9).

15. Nestor Goulart corrobora Gonsalves de Mello a respeito da data da imagem, justificada pelo interesse da Companhia em conhecer a vila: "Em 1630 ainda era importante para a diretoria da Companhia das Índias Ocidentais, em Amsterdam, conhecer detalhes sobre a povoação, para deliberar sobre suas condições de defesa e possibilidades de desenvolvimento, sendo essas alternativas rechaçadas e deliberada a destruição pelo incêndio"; cf. Nestor Goulart Reis Filho (2000, p. 331).

16. Cf.Antônio Gonsalves de Mello (1976, p. 9). 
17.Ver Marcos Galindo e José Luís Mota Menezes (2003).

18. Idem, p. 17.

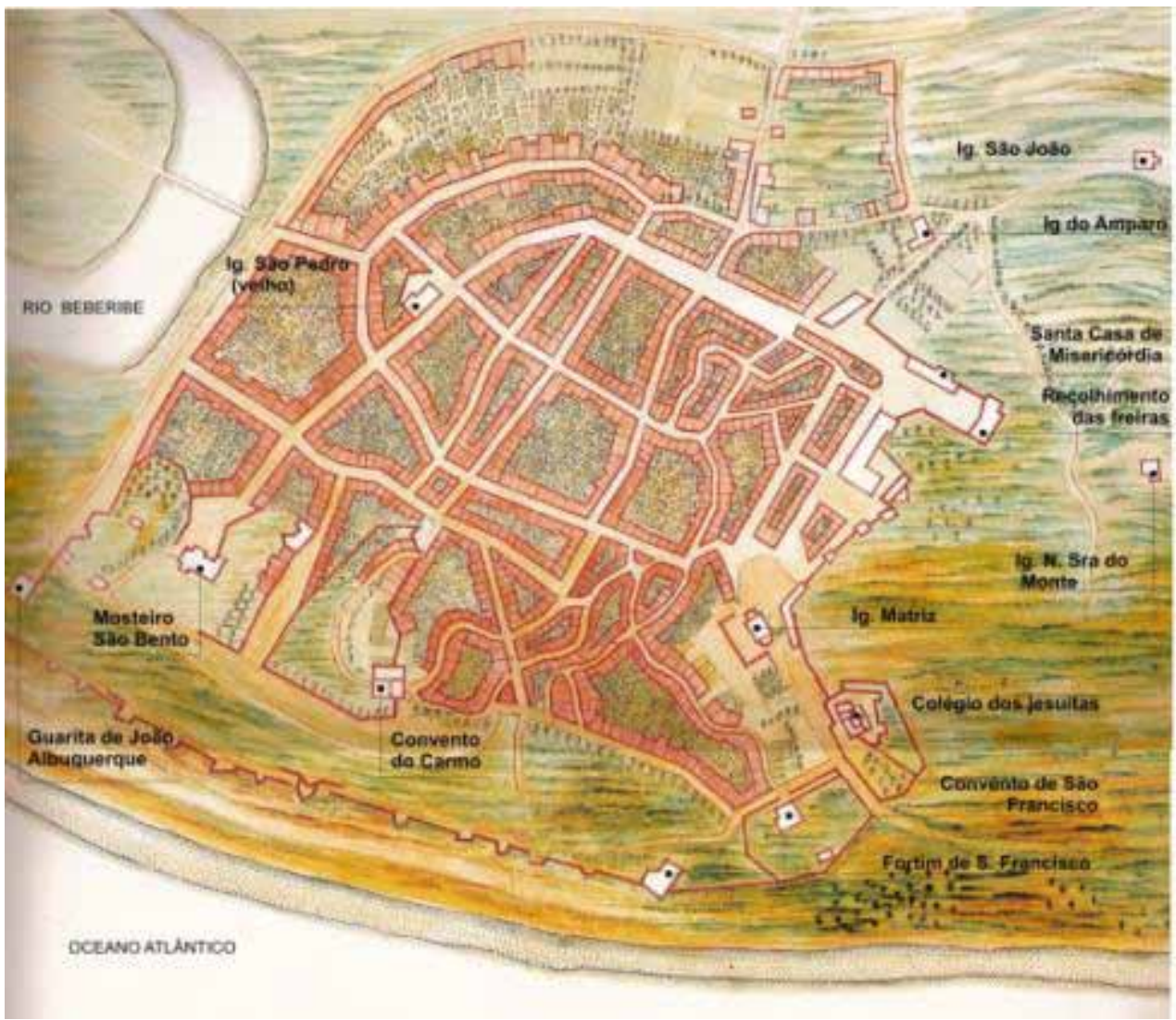

Figura 3 - Identificação dos elementos destacados no Mapa de Olinda. Infográfico elaborado pela autora, utilizando detalhe de Johannes Vingboons, Mapa de Olinda, ca. 1665. Fonte do mapa: Nestor Goulart Reis Filho, 2000.

estada dos holandeses em Pernambuco, e no primeiro período, onde ainda se cogitava ocupar Olinda.

Johannes Vingboons nasceu em 1616, trabalhou como aprendiz com Hessel Gerritz e Willem Blaeu, que na época era cartógrafo-mor da Companhia das Índias Orientais. Um de seus exercícios era copiar mapas antigos, o que de certa forma the aproximara muito das convenções anteriormente adotadas em vários lugares da Europa ${ }^{17}$.

Segundo Mota Menezes, Vingboons fez uso dos levantamentos cartográficos de G. Marcgraf e C. B. Golijath. $O$ desenhista não confeccionou obra original e, sim, transferiu para uma linguagem uniforme e convencional, dentro das características aceitas na época, os desenhos existentes nos arquivos holandeses. A qualidade dessa interpretação é que faz de Vingboons excelente artista da cartografia ${ }^{18}$.

Logo, esses mapas são produtos culturais e, portanto, com linguagem própria que, dependendo do período, estava comprometida, em maior ou menor grau, com a universalidade dos códigos. Segundo Beatriz Bueno, "As 
particularidades gráficas revelam determinadas escolhas culturais, concepções de mundo, estado do conhecimento científico e convenções cartográficas - medidas, códigos de figuração, paleta cromática, grafismos, ornamentos - próprios de cada período"19.

Assim, em outras plantas de Olinda, vamos encontrando similitudes, por exemplo, quanto ao traçado das ruas e a localização dos edifícios, como é o caso da Civitas Olinda, que ilustra o livro de Barléu (Figura 4). Apesar de não ter o mesmo colorido e detalhamento dos quintais, a semelhança entre as imagens é surpreendente, podendo indicar a mesma base cartográfica, usualmente atribuída a Marcgrave.

Outra planta de Olinda que apresenta um traçado urbano nítido, com a representação das áreas de plantio na Vila, é a imagem que ilustra o livro de Nieuhof (Figura 5). Esta planta é interessante por se preocupar em mostrar as áreas onde se localizam algumas das atividades de subsistência aí existentes. Por um lado, junto ao mar, a pesca feita com rede pelos escravos, esboçando seus modos, por outro lado, no arrabalde da vila, variadas plantações que se estendem do rio em direção à várzea. Grandes lotes de cultura diversificada, compreendem, possivelmente, as roças e sítios descritos no Foral.

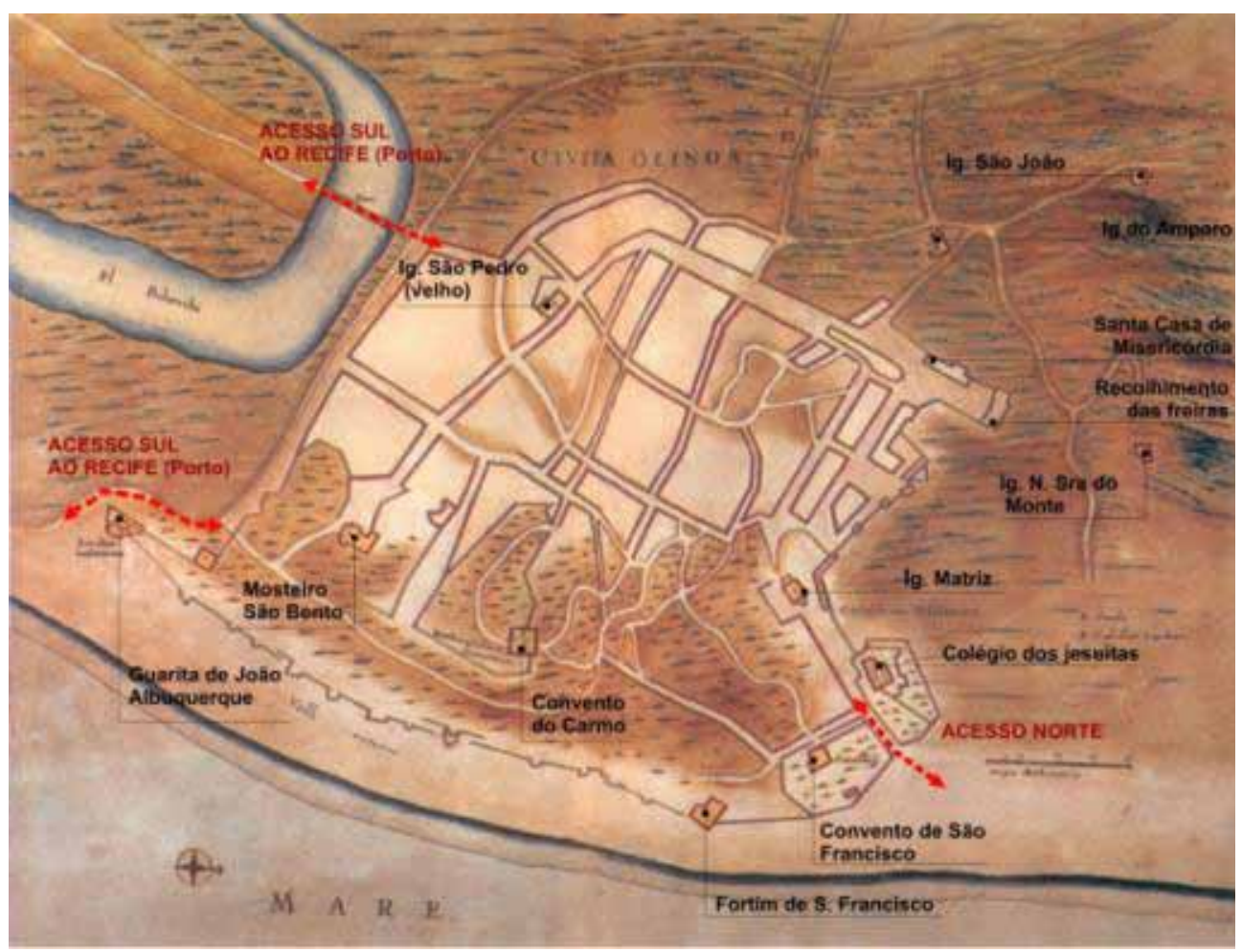

Figura 4 - Identificação dos elementos destacados e dos principais acessos no mapa de Olinda. Infográfico elaborado pela autora, utilizando o mapa Civitas Olinda, de autor não identificado. Fonte da imagem: Gaspar Barléu, 1974.
19. Cf. Beatriz P. Siqueira Bueno (2004, p. 193). 


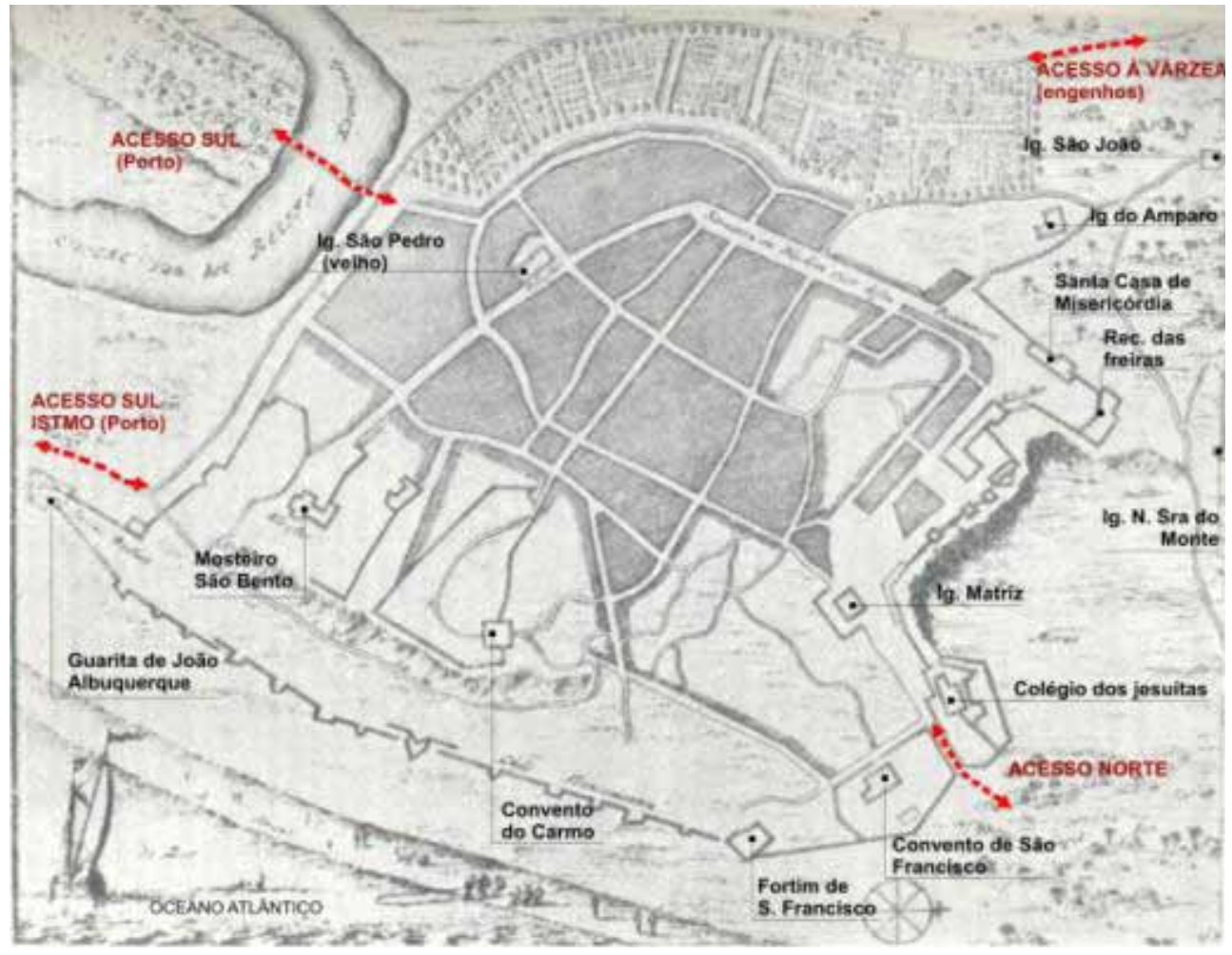

Figura 5 - Planta de Olinda usada para indicação de acessos e edifícios em destaque, com base em gravura que ilustra o livro de Joan Nieuhof, Gedenkweerdige Brasiliaense Zee- en Lant-Reise... (Amsterdã, 1682). Fonte: Joan Nieuhof, 1981.

Em relação às áreas verdes (Figura 6), podemos perceber uma clara distinção entre as zonas representadas. A primeira corresponde a uma borda de natureza "selvagem" junto à vila, com madeira que possivelmente devia servir para fornecimento de lenha e atendimento das necessidades de expansão urbana. Uma segunda área, que se estende da margem do rio até as proximidades da Igreja do Amparo, é nitidamente de plantio e, por seu destaque, deve atender à vila como um todo. Esta região é caracterizada por glebas divididas por vias, semelhantes às quadras da área edificada. Uma terceira área compreende as cercas conventuais e, possivelmente, quintais de quadras de ocupação parcial. Não há menção alguma a tipos de apropriação de caráter doméstico.

O que podemos deduzir é que, em sua maioria, essas plantas se pautavam por preocupações militares. A princípio, informações que subsidiassem a Companhia e suas tropas para conhecer e invadir a vila. Em outro momento, fornecer dados sobre a estrutura e manutenção de uma nova ocupação, sob um novo governo. A justificativa seria esta, pela quase ausência de identificação da arquitetura civil e, consequentemente dos quintais, que são revelados em poucos momentos. 


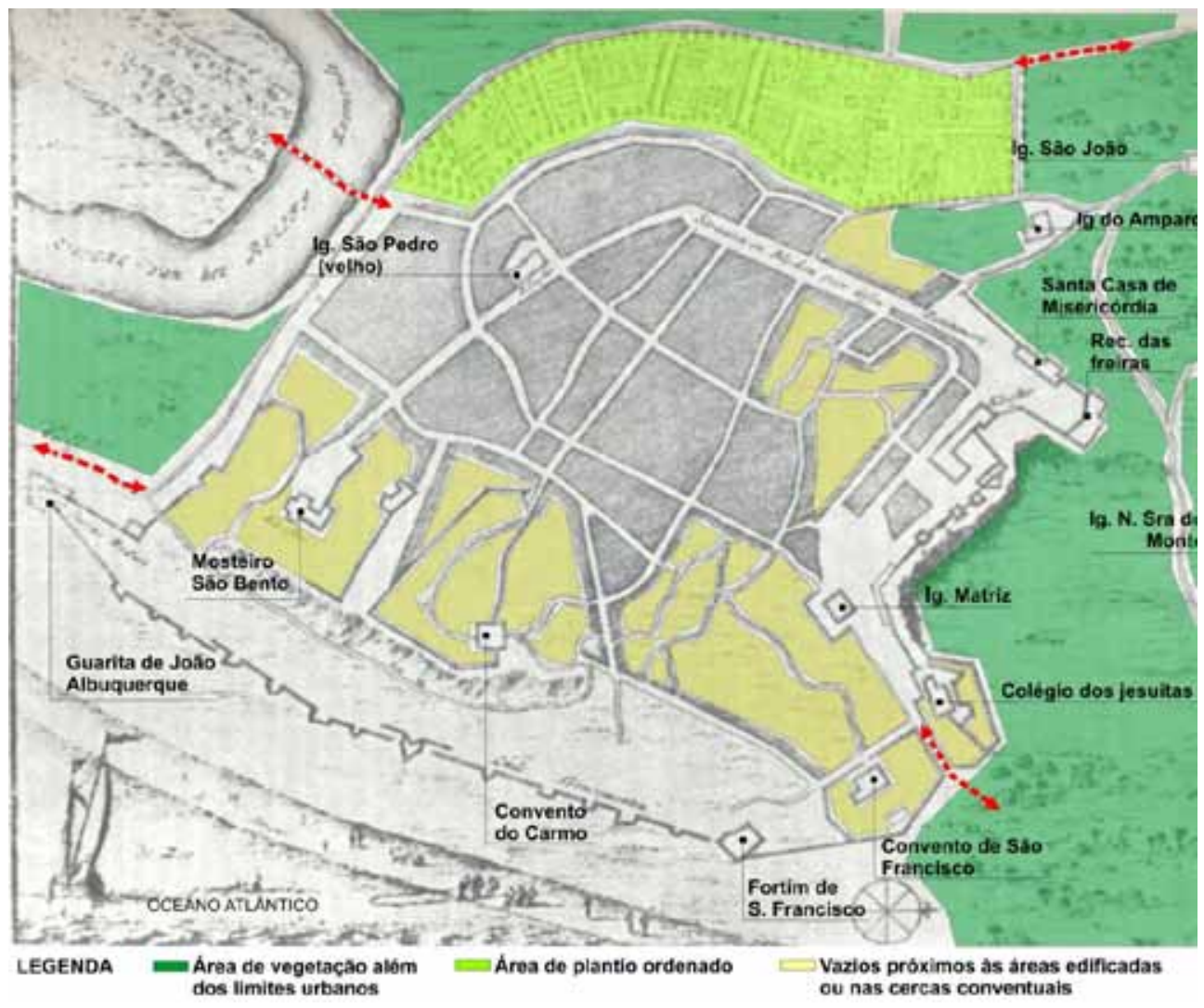

Figura 6 - Planta de Olinda usada para indicação das manchas vegetais na vila, com base em gravura que ilustra o livro de Joan Nieuhof, Gedenkweerdige Brasiliaense Zee- en Lant-Reise... (1682). Fonte: Joan Nieuhof, 1981.

No Civitas é possível observar ruas de traçados orgânicos e com representação mais delicada, situadas nas áreas internas às quadras ou posteriores às edificações, que provavelmente corresponde às ruas de serventias. Estas pouco aparecem nas representações dos primeiros séculos, possivelmente por seu caráter ordinário, servindo de acesso aos carros e cavalos, que não poderia se fazer pela frente, e para despejo dos dejetos (tigres), trânsito dos escravos etc. Em meados do século XVIII, é possível observar nítida referência a tais vias, em Olinda, no quadro que fazia parte da Igreja de São Cosme e Damião em Igarassu e hoje pertence ao Museu da mesma cidade (Figura 7). A antiga vila, já reconquistada pelos portugueses, se refaz. $\bigcirc$ que antes era ruína retoma as feições da agora cidade. Na parte inferior do quadro há uma legenda descrevendo o motivo pintura - a ameaça da peste, que havia matado muitas pessoas na região em 1685.

A imagem inverte o sentido tradicional das representações de Olinda. A começar pelo ponto de observação, que se desloca do mar para o rio. Olinda é enquadrada pelo lado sul, próximo à ponte, que está em primeiro plano. A 


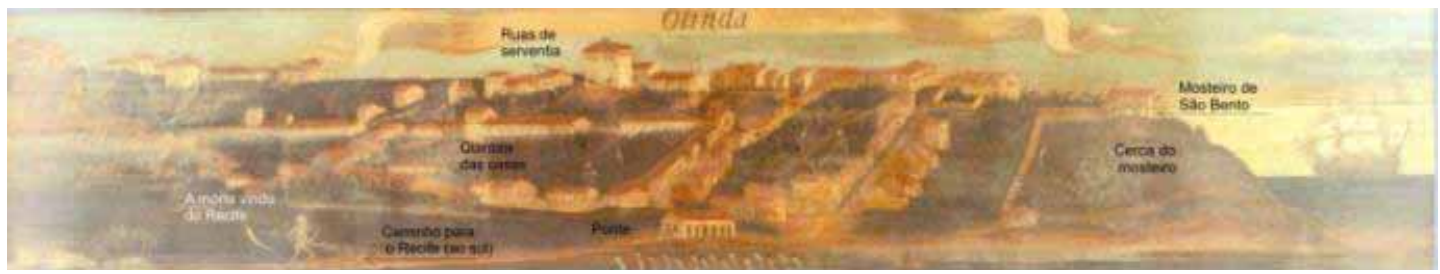

Figura 7 - Olinda. Detalhe de um quadro a óleo (ex-voto), de 1729. Museu de lgarassu, lgarassu (PE). Fonte: Nestor Goulart Reis Filho, 2000. As legendas do infográfico foram acrescentadas pela autora.

20. Na cartografia, a rua de serventia vai surgir mais explicitamente a partir do século XVIII, nos projetos de vilas e cidades, como por exemplo, na planta da Vila de São José, no Rio Grande do Sul; ver Nestor Goulart Reis Filho (2000, p.233).

21. Cf. Helder Carita (1999,p. 29); grifo nosso.
Morte parece vir do Recife e caminha para a cidade, e outras caveiras estão representadas nas cercas e quintais das casas. No extremo direito da figura, ao alto, temos o Mosteiro de São Bento e sua generosa cerca.

"esvaziamento" dos quintais promove uma leitura sob outra perspectiva. As casas formam as linhas limites das quadras, com grande área verde em seu interior, representada como um tapete verde no solo, sem volume, nem árvores. Porém o mais interessante são os caminhos formados nesse interior, ao modo das ruas de serventia, para atender aos fundos dos quintais. Quase todas as quadras apresentam essas suaves linhas orgânicas que as penetram.

A quadra mais central da composição, por estar bem sedimentada em relação às construções, revela falhas propositais na sequência de casas, para favorecer $\mathrm{o}$ acesso aos interiores e a abertura das ruas de serventia ${ }^{20}$. Na imagem, os quintais estão presentes na maior parte do solo urbano, e quase não há habitação sem uma área verde correspondente.

Constatamos também que a forma das quadras, assim como a das ruas, tende à ortogonalidade. Não sendo isso possível, por questões topográficas, adaptam-se às superfícies existentes, tornando-se, em alguns momentos, esconsas, triangulares e assim por diante. Helder Carita mostra esse modelo português de parcelamento urbano da seguinte forma:

A estrutura de quarteirões e a estrutura de loteamento caracterizam igualmente as formas urbanas portuguesas, apresentando três tipos fundamentais que se desenvolvem ao longo do tempo, mas ao mesmo tempo coexistindo em várias situações. $\bigcirc$ primeiro tipo de quarteirão é o quarteirão medieval, estreito e comprido, com lotes que vão de lado a lado do quarteirão, definindo uma alternância de ruas de frente e de traseira. $\bigcirc$ segundo, mais tardio, é o quarteirão em que existem lotes dispostos costas-com-costas virados para faces opostas do quarteirão. O terceiro tipo de quarteirão é quadrado, ou tendendo para o quadrado, e tem lotes virados para suas quatro faces; este último, permitindo uma melhor utilização do espaço urbano, surge a partir do século XVR1.

Observando o Mapa de Olinda, podemos verificar que em Olinda a tendência de parcelamento e apropriação dos lotes na quadra, mesmo quando não quadrada, dá-se pela ocupação em todas as faces. Porém, ao compararmos as plantas da Vila (Figura 8), a ocupação da quadra ocorria de modo subordinado ao relevo. 

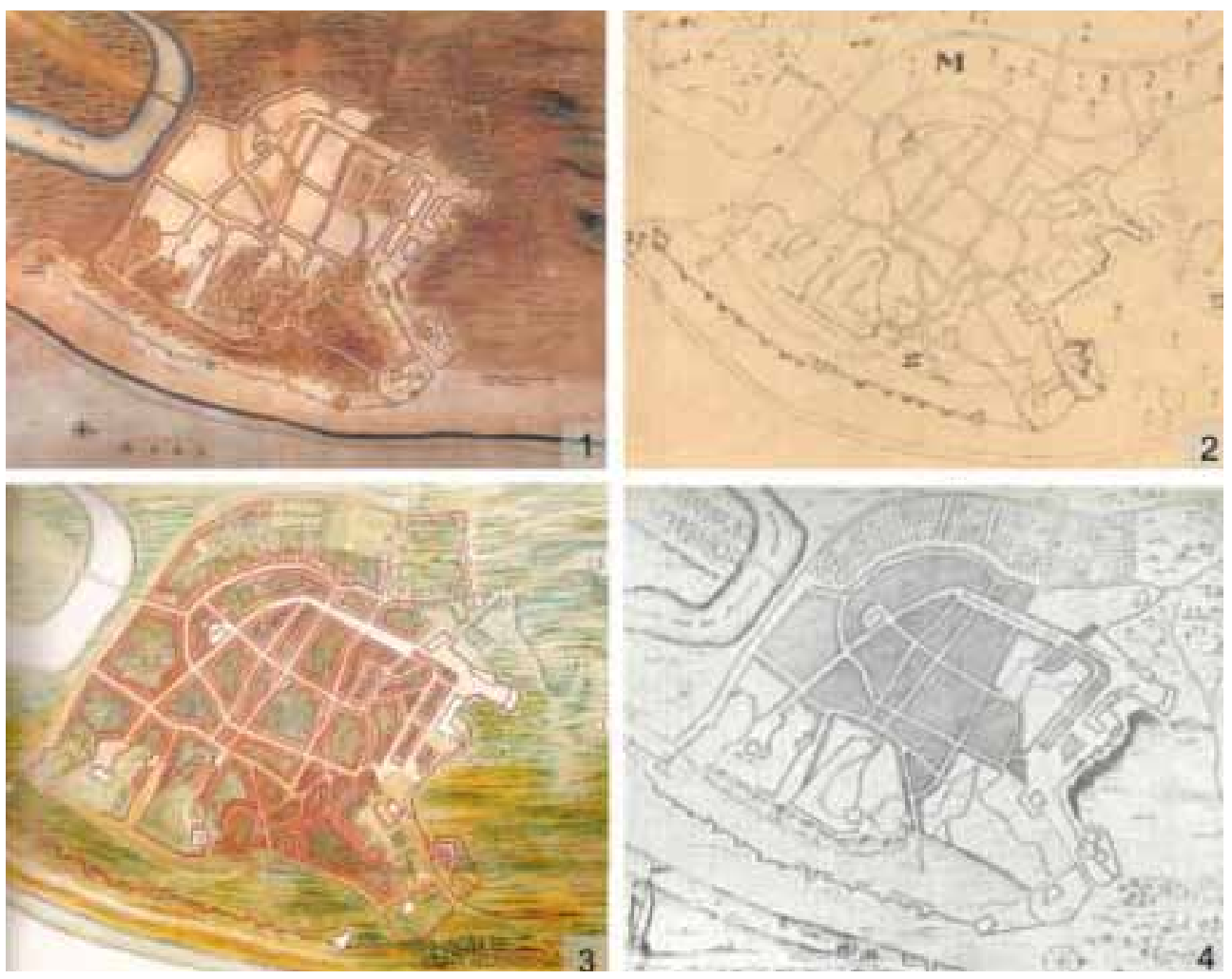

Figura 8 - Comparação entre: 1. Mapa Civitas Olinda (1648); 2. Mapa existente em Afbeelding van drie Steden in Brasil als Olinda de Phernambuco, Maurits Stadt ende Reciffo, de Cornelius Golyath (1648); 3. Mapa de Olinda, do Atlas Vingboons (1665); e 4. Mapa sem título, publicado em Gedenkweerdige Brasiliaense Zee- en Lant-Reise... (1682), de Johan Nieuhof.

Além disso, havia aí uma hierarquização do valor do lote, sendo mais cobiçados os situados mais próximos ao cume das colinas. Podemos verificar a valorização dessas áreas no relato do reverendo João Baers, que veio a Pernambuco junto com a esquadra da Companhia: "As casas [...] todas com largas escadarias de pedra, porque, as pessoas de qualidade moram todas no alı" 22 . A parte mais importante da vila era a área próxima à igreja Matriz e à da Misericórdia, junto à rua dos Nobres, por exemplo. Quanto mais alto a moradia se localizasse, mais bem instalado o morador estaria na escala social. O relevo deixa de ser apenas característica topográfica, para representar a distribuição social, confirmando a impressão registrada nos relatos dos antigos viajantes e as normas da Carta Foral.

Além dos fatores sociais, a posição em que a edificação se localiza no lote começa a desenhar uma perspectiva própria do período, pois inicialmente a construção é rente à rua, suas paredes tomando os limites do lote, deixando apenas uma área verde ao fundo: o quintal. Este muitas vezes se estendia até a outra rua e, em alguns momentos, até a denominada rua de serventia.

22. Cf. João Baers (2004, p. $39-41)$. 
A quadra, o lote e o quintal

Aqui vamos observar a inserção do quintal na composição da quadra. Em tal contexto, podemos especular como os quintais se apresentaram nas relações de vizinhança e, mais adiante, na residência dos primeiros moradores da vila e, assim, permitir o confronto com as casas atuais do sítio histórico, indicando suas permanências e participação na construção da paisagem de Olinda.

Nestor Goulart caracteriza as quadras da primeira fase do urbanismo no Brasil da seguinte forma:

As quadras, quando completamente edificadas, compunham-se de uma linha contínua de construções, dos lados das ruas, com um grande vazio constituído pelos quintais, na parte interior. Os telhados das casas, de duas águas, que as lançavam para a rua e para o interior dos lotes, coroavam o conjunto e, algumas vezes, formavam uma segunda linha de continuidade. Internamente, porém as dimensões das quadras sendo grandes, estendiam-se os quintais em vazios surpreendentes, que contrastavam de modo violento, com a aparência de concentração das vias públicas ${ }^{23}$.

Em Olinda, existem alguns tipos diferentes de apropriação de quadra, pois apresentam-se bastante dependentes da situação na topografia e, consequentemente, do arruamento. Na Figura 9, temos uma apropriação de quadra que faz limite com o Convento do Carmo. Nela observamos que, embora a arquitetura seja mais recente, o loteamento remonta ao parcelamento apresentado no Mapa de Olinda e similar ao dos edifícios remanescentes do século XVI. São lotes de pouca testada, condicionando uma arquitetura adensada e solução da coberta em duas águas, formando, como diz Nestor, uma segunda linha de continuidade, e, pela experiência urbana, uma barreira compacta entre a rua e as áreas não edificadas. Neste caso, a quadra está ocupada por construções apenas em um dos lados, por fazer limites com o convento. Há outros casos, como junto à lgreja do Amparo, em que a solução se repete, porém com uma via secundária ao fundo dos lotes. Entretanto, a constituição das quadras apresenta variações em relação à forma e apropriação dos lotes.

Percebemos que a construção da quadra resulta, em maior escala, do plano proposto pelo Foral, respeitando a aptidão de áreas para determinados fins; e, de modo mais específico, de uma concepção que considera, como elementos significativos, as igrejas e o direcionamento das vias. Isso corrobora a tendência de expansão a oeste, e, principalmente, as características do sítio. Ao fazermos a sobreposição da planta altimétrica de Olinda ao traçado da antiga vila (Figura 10), podemos concluir que as ruas principais, em sua grande maioria, foram traçadas nas linhas de cumeadas dos montes (a linha vermelha) ou nos espigões (divisor de águas - a linha laranja). Deste modo, a partir de uma classificação especulativa das ruas, foi produzido um esquema cujo princípio se 


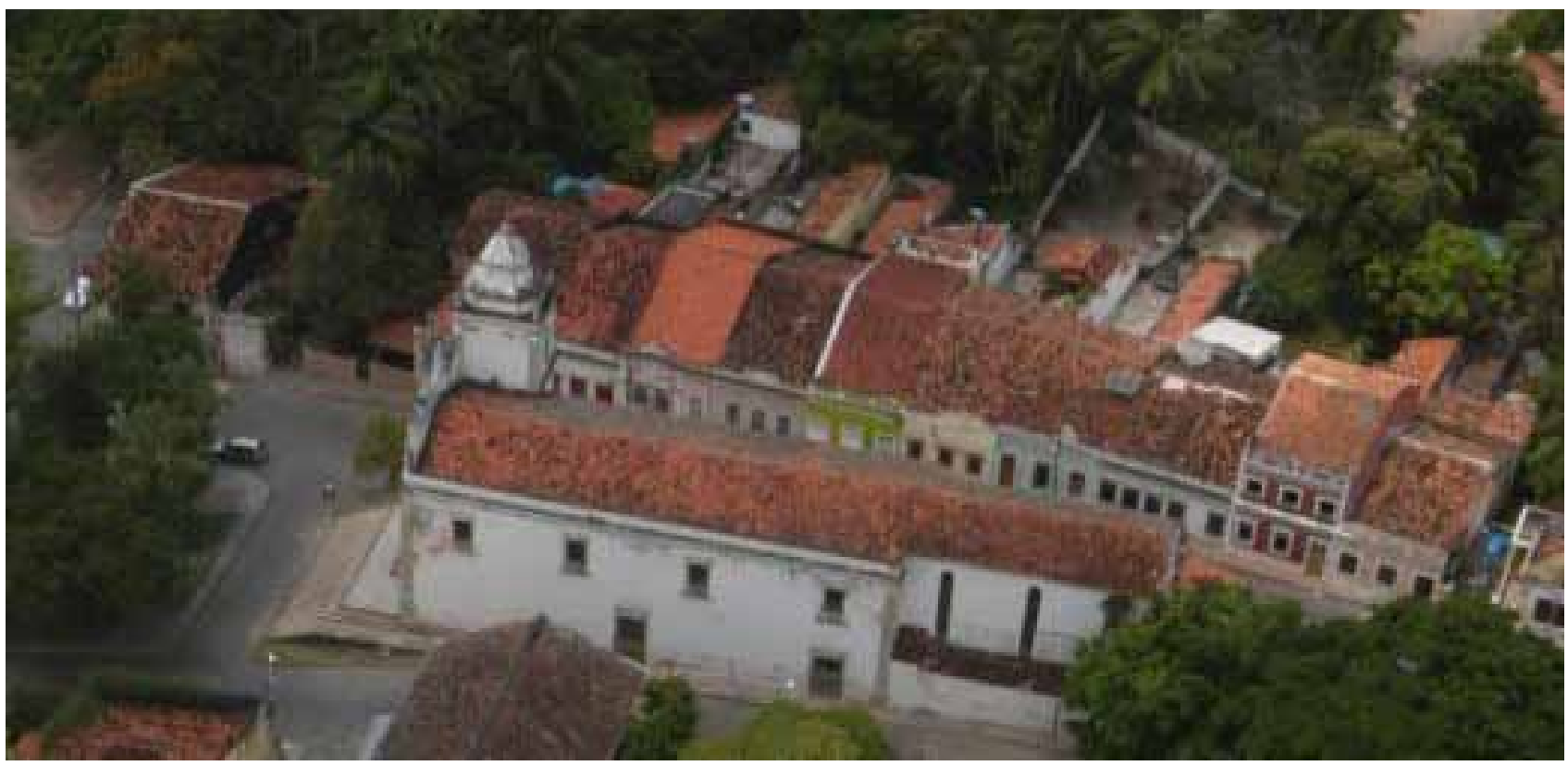

Figura 9 - Casas geminadas e lotes compridos, 2006. Fonte: fotografia de Passarinho [Francisco Ferreira], Prefeitura Municipal de Olinda.

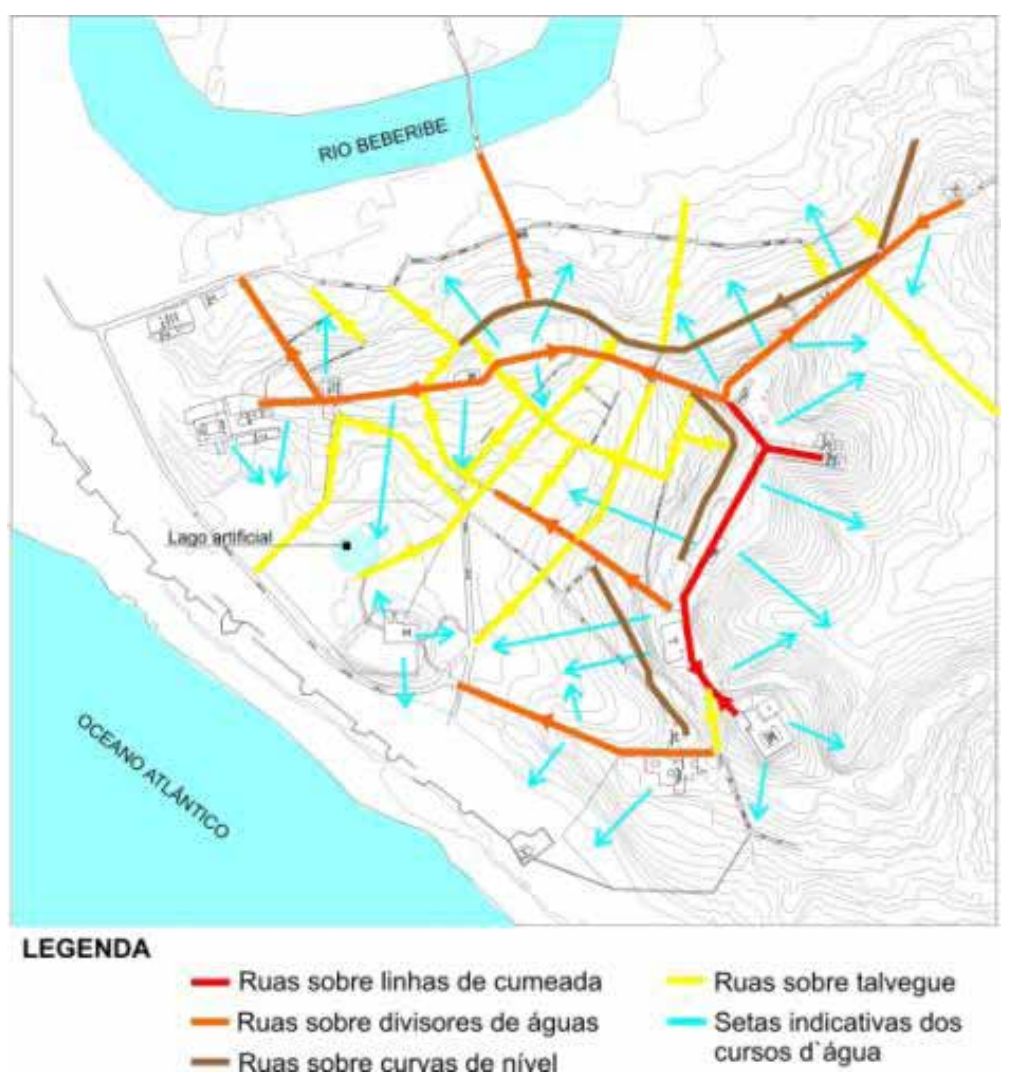

Figura 10 - Estudo da relação entre a topografia e descidas de águas, e o traçado urbano, elaborado pela autora. Fonte do mapa altimétrico: Prefeitura Municipal de Olinda. 
24. Cf. Idem (2004, p. 20).

25. cf. PROJETO Foral (2000, p. 16-17).

26. Ibidem. baseia em sua relação com as características do sítio, bem como na contribuição desse sistema para o escoamento das águas pluviais. Novamente se comprova a importância da topografia no desenho da Vila e, consequentemente, na locação dos quintais.

Outro tipo de via é a que se situa sobre as linhas de talvegue da topografia (linha amarela). Funcionando como uma espécie de calha, elas captam as águas de chuva e as direcionam para cołas menores. Tal apropriação está em parte representada pelas ruas de serventia, que, além de atender a funções mais ligadas ao cotidiano doméstico, servem para o escoamento.

Segundo Nestor Goulart, o traçado das ruas, durante o período colonial, atendia a duas referências básicas: os acessos e o caminho das águas. "No caso da vila de São Paulo, cujas casas eram todas construídas de taipa, os cuidados deveriam ser redobrados"24.

Em Olinda, a relação entre a vila e as formações geográficas já está presente na Carta Foral. Duarte Coelho se refere recorrentemente a termos específicos como: "assentos desse monte e fraldas dele", "várzeas", "campinas", "alagadiço", "mangues", "ribeiro", "lombada do monte", "arrecifes", "montinho"25, entre outros. O Foral também relaciona esses elementos com os usos, incluindo parte da infraestrutura, pois revela, em determinado momento, que o desenho da vila também leva em consideração o movimento das águas: "O monte de Nossa Senhora do Monte, águas vertentes para toda parte"26.

Da classificação anterior, podemos caracterizar ainda um quarto tipo de rua, que acompanha as curvas de nível do terreno. Elas geralmente são paralelas às anteriores e formam quadras estreitas e compridas. Aproveitam, sempre que possível, as diferenças de cotas do relevo para caracterizar usos específicos no interior dos lotes. Um bom exemplo é o conjunto de casas das áreas comerciais que se serve do andar inferior, junto à rua, para loja (Figura 11 ).

A quadra ganha o desenho que melhor se adapta a esses princípios e, neste momento, recebe dimensões menores na largura, com grande declividade, dificultando sobremaneira o desmembramento em outros lotes.

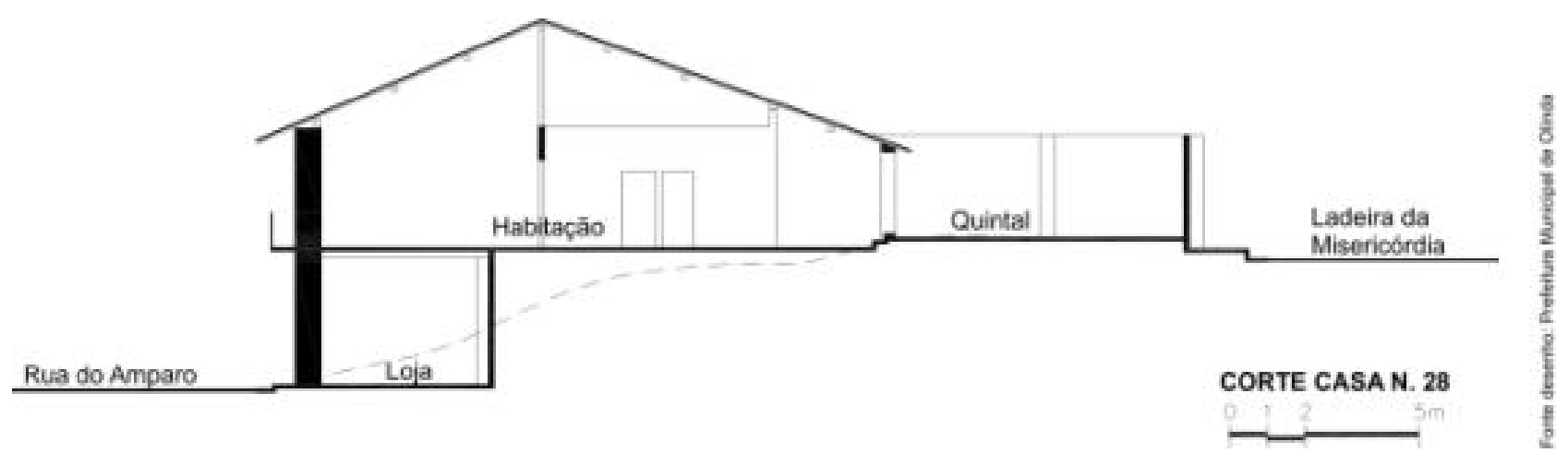

Figura 11 - Corte esquemático da casa n. 28 da rua do Amparo. Fonte: Prefeitura Municipal de Olinda. 
Apresentando zonas distintas de apropriação - quintal e compactas massas edificadas - a quadra é um fragmento urbano que, embora suas dimensões não estejam especificadas ou padronizadas por documentos textuais, está subordinada à concepção urbana inicial. Esta última, voltamos a afirmar, presente desde a escolha do sítio até a composição do lote.

Na abertura das ruas e na construção das quadras, havia apenas uma aparente liberdade encobrindo uma lógica de apropriação que se orientava, por exemplo, pelo escoamento de água. É nítida a preocupação comum de manter os limites dos quintais paralelos à construção e ortogonais à rua ${ }^{27}$.

$\bigcirc$ conjunto formado pelos quintais de Olinda aponta, em cada quadra, para uma investigação que considere essa relação. Portanto, para o estudo da formação destes espaços tornou-se fundamental analisar não apenas o lote, mas também o modo como este se comporta em conjunto, pois isto auxilia na determinação do espaço, dos limites, e de sua forma e inserção na vila.

Utilizaremos novamente o Mapa de Olinda, pois os quintais aí estão representados e poderemos aferir também outras áreas afins, como é o caso das cercas conventuais.

No mapa (Figura 12) vê-se claramente o desenho sinuoso que a vila adota e os corações verdes das quadras, onde se instalam os quintais. A implantação da vila bem como seu arruamento, discutidos anteriormente, definem um tipo de quadra irregular, que se molda à topografia e ao encaminhamento de

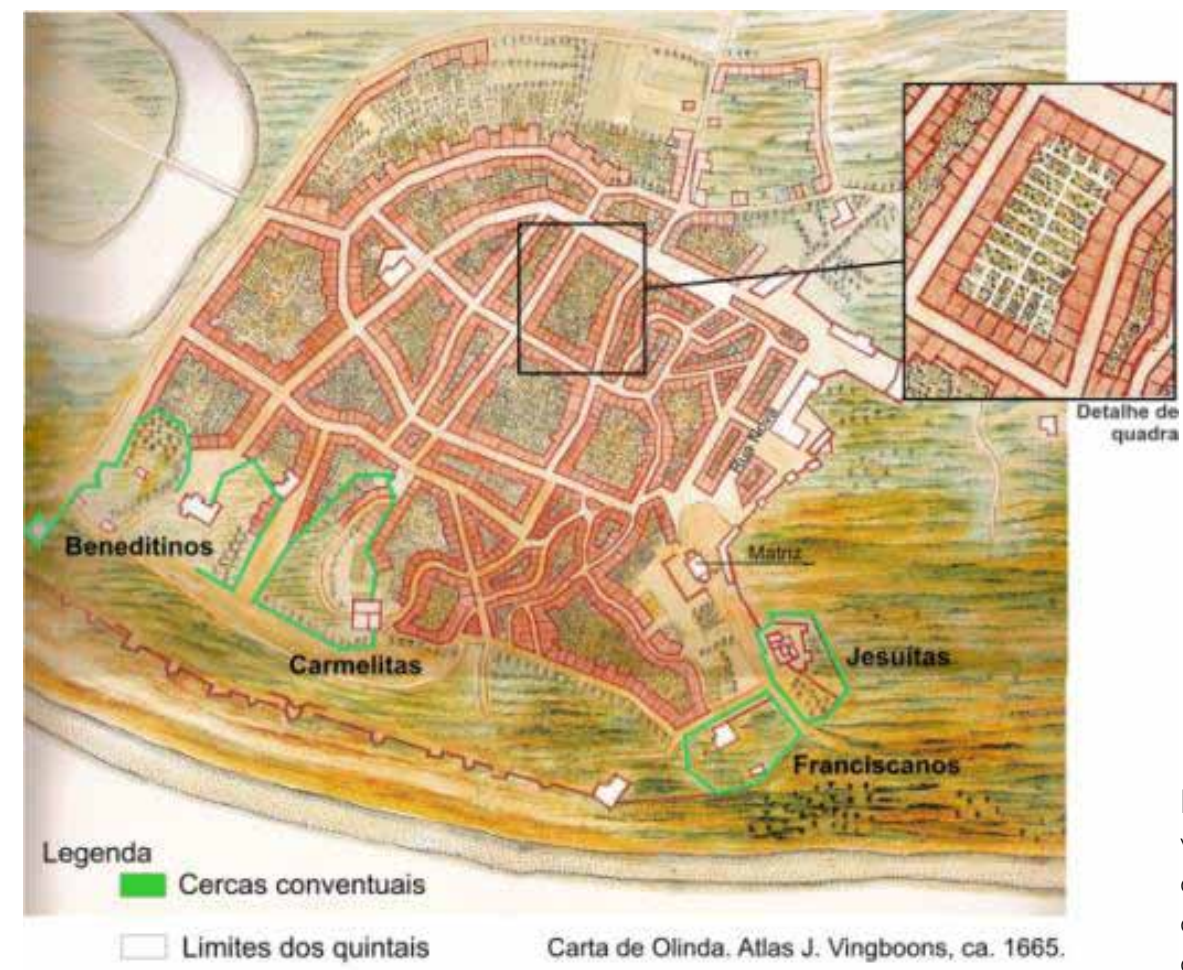

Figura 12 - Indicação das cercas conventuais e detalhe da composição dos quintais na quadra, infográfico elaborado pela autora sobre Mapa de Olinda, do século XVII, existente no Atlas de Johan Vingboons. 
determinados pontos de interesse da época, como as edificações religiosas. Mesmo submetida a esta ordem urbana, a quadra demonstra ter estágios de sedimentação indicados pela diferença da apropriação do solo, no sentido centroperiferia.

Na periferia, zona mais próxima aos limites urbanos, os quintais se mostram mais "frouxos" no terreno, possuindo dimensões muito maiores que os das quadras centrais. $\bigcirc$ desenho é menos compactado, havendo algumas quadras ainda "abertas", ou seja, com lotes sem edificação.

No núcleo mais antigo, próximo à matriz, vê-se um aumento na quantidade de ruas e consequente diminuição da dimensão das quadras; e, por extensão, também dos quintais. Os maiores, nessa área, restringem-se aos das casas da rua Nova, área nobre da vila, embora, apenas as da parte norte, pois a acentuada declividade do terreno não favorece a ocupação da parte sul. Outro motivo para a diminuição das dimensões das quadras deve ter sido o valor desse solo - quanto mais alto mais valioso. Como se viu, a sociedade podia se ver representada pela topografia do sítio.

Mesmo a quadra não tendo medidas regulares, os lotes relativamente o eram (Figura 13). Neles, a proporção entre edifícios e quintais é, em sua maioria, desigual. Os últimos, em geral, eram de dimensões maiores que a dos edifícios, em alguns casos, mais que o dobro da área construída.

Nas quadras próximas à antiga zona comercial dos Quatro Cantos, considerada área central, a primeira quadra que tomamos como referência é a delimitada pelas atuais rua Prudente de Moraes, ladeira da Misericórdia e rua do
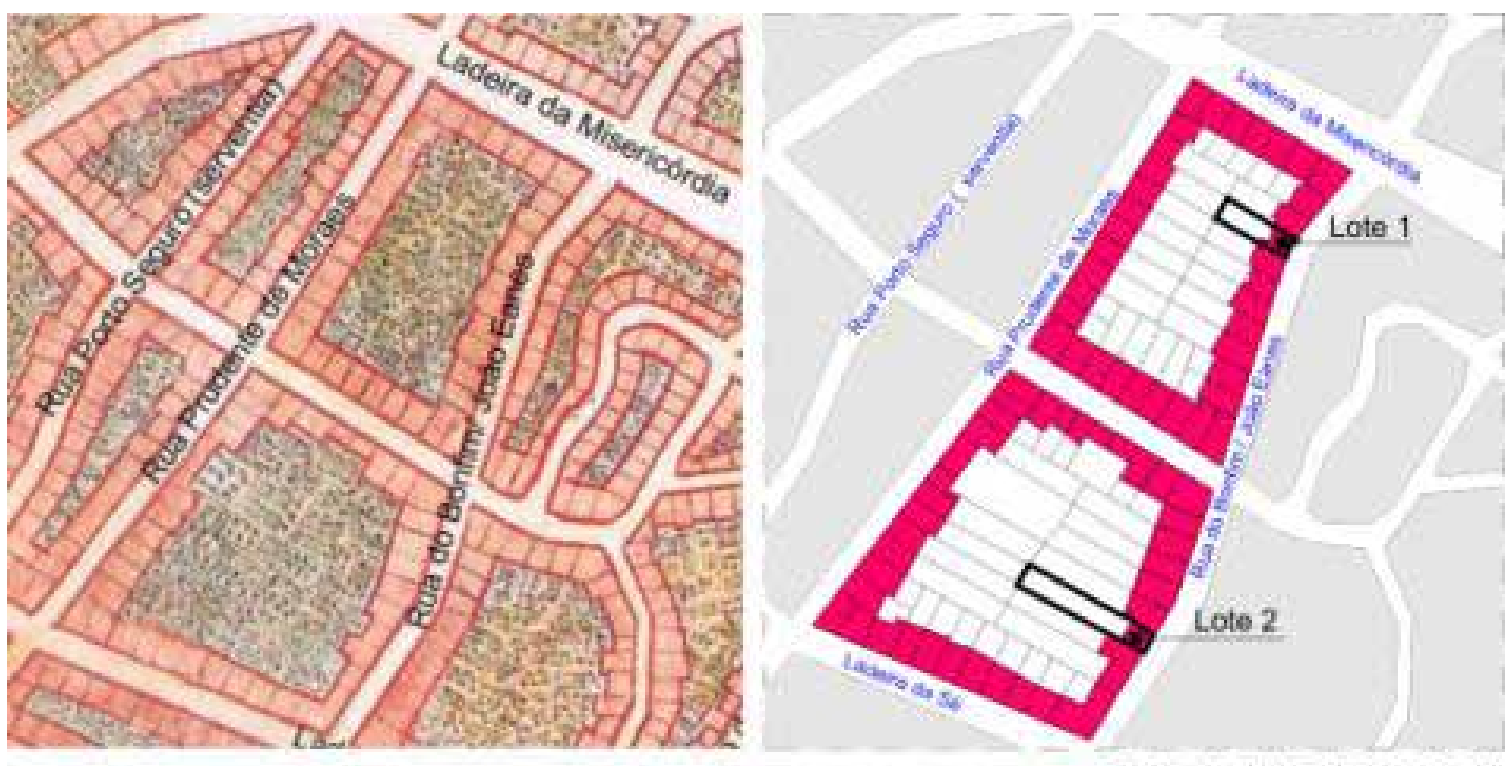

PLANTA BAIXA DAS QUADRAS

(levantamento a partir da Planta de Olinda de 1630, Atlas Vingboons)

Figura 13 - Estudo da composição dos lotes na quadra, em Olinda, elaborado pela autora sobre Mapa de Olinda, do século XVII, existente no Atlas de Johan Vingboons. 
Bonfim. A proporção entre edifício e quintal, do lote 1, é de aproximadamente 1:2.28, isto se considerarmos a imagem apresentada anteriormente ${ }^{28} . \mathrm{Na}$ segunda quadra, a que the faz fronteira (delimitada pela ladeira da Sé - antiga rua dos Palhais -, a Prudente de Morais e a rua do Bonfim), a proporção do lote 2 é de aproximadamente 1:4.42. Estes dados foram levantados a partir da carta holandesa antes citada.

É provável que o Mapa de Olinda seja uma proposta de ocupação holandesa da antiga vila, idéia que José Luis da Mota Menezes e Vanildo Cavalcanti compartilham, pois o adensamento das edificações representado no mapa não corresponde a outras imagens da vila. Ao compararmos o Mapa de Olinda com a vista intitulada Marin D'Olinda de Pernambuco (ca. 1630), logo percebemos que não há correspondência com a parte das edificações representadas no primeiro (Figura 14). Sabe-se que o objetivo da vista é revelar o espaço urbano, e isto é perceptível quando se verifica que a situação dos edifícios religiosos corresponde, com certo grau de precisão, às localizações atuais dos mesmos. $O$ mosteiro de São Bento, por exemplo, apresenta-se na vista ainda bem isolado e há alguns outros vazios entre ele e o convento franciscano. Assim sendo, a proporção acima referida, entre área edificada e não edificada, devia ter valores diferentes, em que a área de quintal, novamente, seria bem maior.

Quando é representada a vegetação dos quintais (destacada na imagem), observa-se referência a árvores de grande porte, adensadas no espaço,

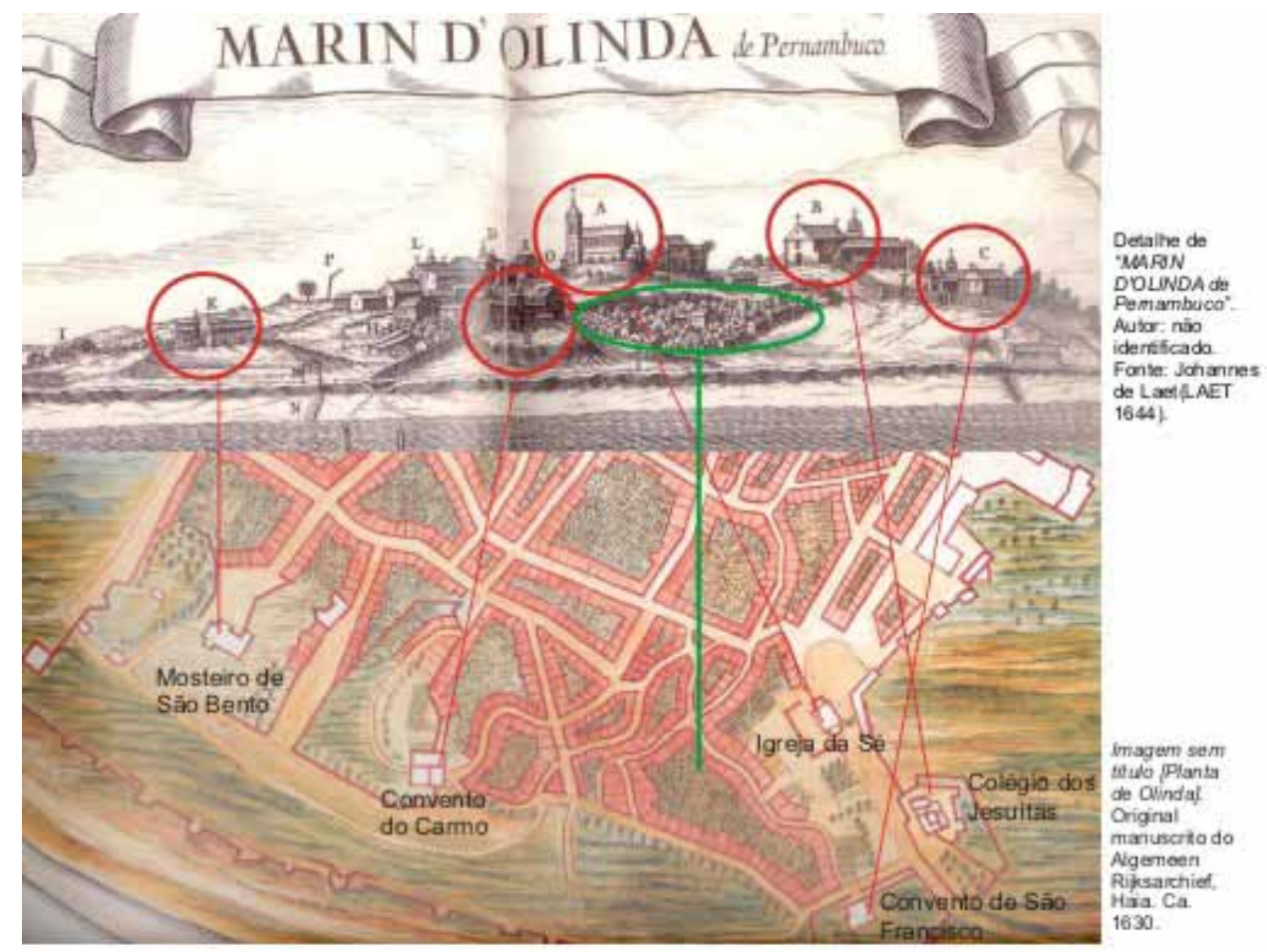

28. A escolha do lote se deu por ter dimensões semelhantes às da maior parte dos lotes da quadra.
Figura 14 - Estudo comparativo entre a vista em Marin D'Olinda de Pernambuco e - mapa de Olinda do Atlas de Vingboons, elaborado pela autora, identificando os edifícios destacados nas imagens e os quintais. 
29. Cf. Gaspar Barléu (1974, p. 40); grifo nosso. permitindo não apenas situá-las como também perceber suas formas e dimensões. Na comparação entre as duas imagens da Vila de Olinda, podemos evidenciar, além das referências dos elementos construídos, a morfologia desses espaços e a distribuição da vegetação no terreno. Este tipo de apropriação deve ter sido suprimido na maior parte da vista, pois o objetivo dela era informar o máximo de dados do espaço urbano, o que de fato seria omitido se as copas das árvores fossem reproduzidas nos demais quintais.

Na área próxima ao Mosteiro de São Bento, a vegetação urbana deveria ser tal que Barléu comenta: "Na região superior da cidade, estava o mosteiro de S. Bento, protegido pela natureza e pela sua construção"29.

No Mapa de Olinda, o adensamento das áreas edificadas pode não corresponder à realidade da época, o arruamento, entretanto, corresponde ao traçado atual da cidade. Podemos deduzir, portanto, que as quadras mais centrais tenham dimensões menores e formato tendendo ao quadrado. A apropriação do lote forma núcleos vegetais, pois as edificações se situam rentes às ruas, sem recuos laterais. Na atualidade, tais centralidades permanecem e, na perspectiva da rua, os quintais assumem uma aparência indivisa.

Na análise das quadras, foi possível constatar que a largura dos lotes não era de dimensões uniformes. As casas situadas na rua Bispo Coutinho, antiga rua Nova, por exemplo, possuem testadas em torno de 9 metros. Esta dimensão corresponde, possivelmente, ao seu grau de importância enquanto antiga área nobre da vila, pois, como veremos mais adiante, em outras regiões as medidas são menores. A largura das casas não deve ter sido alterada ao longo do tempo, pois as construções se situavam no limite do lote e, portanto, não havia espaço para ampliações.

Nas casas da rua do Amparo, as testadas dos lotes têm dimensões que variam do mínimo de 4,5 metros a raros 8 metros, aproximando-se, na maioria, a 6 metros. Portanto, as medidas das larguras das fachadas encontradas nessa parte da cidade são menores que as das levantadas na antiga rua Nova.

Há lotes de testadas ainda mais estreitas, como podemos verificar nas casas de n. 92 e n. 94, na Estrada do Bom Sucesso, que vai da Igreja do Amparo em direção à de Nossa Senhora do Monte, tendo, respectivamente, 3, 91 e 3,61 metros de frente. Embora no Mapa de Olinda não haja delas referência, observamos cotas similares em lotes existentes no interior da vila, como é o caso das casas n. 280 e n. 314 da atual rua Prudente de Morais, antiga rua da Sarralheira, indicadas nos mapas do século XVII. Essas casas têm 4,22 e 3,1 metros de testada. Percebemos, consequentemente, uma gradação quanto à frente dos lotes, que variam de 3 a 9 metros, dependendo de sua situação na vila. De modo aproximado, pode haver uma tendência para valores múltiplos de 3.

Talvez essa relação métrica não seja aleatória, podendo estar relacionada com as reformas urbanísticas que ocorreram em Lisboa no fim do século XV e princípio do século XVI. Quando Carita se refere ao processo urbanístico da Vila Nova de Andrade, datando seu início em 1498, deixa evidente que havia um plano de urbanização baseado em lotes de métrica e 
geometria precisas. Ao analisar o contrato de 1498, documento anexo ao testamento de Luis de Atouguia, conclui:

Nos termos do acordo, os Andrades doavam a Lopo de Atouguia um lote na nova urbanização, qual devia respeitar "hua rua que tem ordenado de se por ali fazer", confirmando a existência de um plano de urbanização prévio. $\bigcirc$ documento transcreve ainda as medidas deste chão: "doze braças de largo [26,4 m] e seis de largo [13,2m]". Encontramo-nos num universo de métricas e proporcionalidades afectas à mesma mentalidade moderna que identificamos nas grandes reformas urbanas promovidas pela Casa Real na Ribeira e centro da cidade. Afastamo-nos de uma urbanística medieval, com matriz de desenvolvimento a partir de um modelo linear de rua (direita) com travessas, confrontando-nos aqui com uma conceptualização abstracta de traçado urbano baseado num módulo geométrico ${ }^{30}$.

Embora em Olinda ainda não tenha sido identificado nenhum documento que comprove a existência de um sistema de medidas, há que se atentar para a permanência, até os dias atuais, de conjuntos de lotes de larguras similares e que se localizam por zonas. Este tipo de aferição requer uma investigação específica, que possa levantar com maior precisão as dimensões dos lotes. Nesses, embora possam abrigar-se em alguns casos alterações na arquitetura da casa, mantém-se a composição de lotes estreitos e casas geminadas.

No que se refere às áreas de quintais, as fontes textuais revelam que o espaço do quintal era delimitado por cercas ou muros, que podiam ser de taipa, estreitos, seguindo em continuidade as paredes da edificação. Contudo, não se encontrou nenhuma referência ao quintal como lugar de regulação, que tivesse métrica ou forma definida.

No Mapa de Olinda há uma profusão de signos que constroem um discurso sobre a paisagem. A partir desses sinais, indícios e símbolos, tentamos, de outro modo, especular acerca do quintal em Olinda, observando seus pormenores e sua representação, e por diversos suportes buscamos encontrar traços em comum que caracterizam esse espaço.

Cada vez mais observando os detalhes das cartas, podemos ver que, em certos exemplares da iconografia histórica, os quintais ganham uma convenção formal, que se caracteriza por forte influência do desenho geométrico, havendo uma notável distinção entre as áreas de quintal e as que ainda não o são. Em Vingboons, o preenchimento dos quintais apresenta um repertório de signos alusivos à vegetação, que se repetem em todos em arranjos diferenciados. Esses ícones podem indicar determinados usos e que estes são constantes.

Sobre o sistema de representação, devemos considerar que:

Métodos tradicionais antes usados nos mapas manuscritos logo passaram a orientar os que coloriam os impressos, a tal ponto que em quase nada mudou as convenções então estabelecidas durante longo tempo. Florestas, bosques e propriedades eram iluminadas na cor verde; colinas em marrom ou preto; cidades em vermelho; o mar, lagos e rios em índigo (anil); e assim por diante ${ }^{31}$.
30. Helder Carita, apud Maria Helena Barreiros (2001, p. 19).

31. Cf. Marcos Galindo e José Luís Mota Menezes (2003, p. 17). 
32. Cf. Beatriz P. Siqueira Bueno (2004, p. 206).

33. Cf. Manoel de Azevedo Fortes (1728-1729), apud Beatriz P. Siqueira Bueno (2004).
Muito desse tipo de simbologia adotada nesse período para descrever as áreas de quintais - e neste caso por Vingboons - será, por exemplo, assimilada pelos tratados posteriores. Segundo Beatriz Bueno, a partir desse mesmo século há uma transformação na produção cartográfica, evoluindo de uma representação mais naturalista para outra mais abstrata. "Os motivos foram sucessivamente convencionados, e a natureza representada por meio de pictogramas (sistema primitivo de escrita no qual as idéias são expressas por meio de figuras simbólicas), ideogramas (sinal que exprime uma idéia) e outros símbolos gráficos (tramas, variação de valor, etc)." ${ }^{32}$

No mapa, os quintais são representados como um espaço composto de vários elementos simbólicos, que se repetem em diferentes arranjos entre lotes vizinhos. As árvores, quando nas áreas de quintal, encontram-se ordenadas em quase todos os momentos. Essa ordenação diferenciada da natureza talvez reflita uma mudança de status do elemento vegetal, o que a princípio representava o selvagem, ao ser incorporado no espaço urbano passa por um processo cultural, que confere à espécie uma nova condição.

A representação das árvores no Mapa de Olinda se aproxima muito das simbologias empregadas por desenhistas dos séculos XVI e XVIII, denunciando a existência e manutenção das convenções (Figura 15). De 1560 a 1756, o ícone que representa a árvore, por exemplo, tende a ter menos detalhes, conservando, cada vez mais, apenas traços essenciais para sua identificação. Seu perfil, por exemplo. A floresta que circunda a vila é representada por uma textura colorida nos tons de terra (ocre) e de vegetação (verde), compreendendo deste modo um maior grau de abstração.

Ao tratar da representação simbólica, é oportuno destacar um trecho de $\bigcirc$ engenheiro portuguez ${ }^{33}$, embora escrito posteriormente ao mapa de Vingboons:

Os pumares se riscaõ com arvores iguaes, e igualmente compassadas humas de outras, no que só se destinguem dos olivaes, e arvoredos, que naõ guardaõ regularidade [...] o corpo

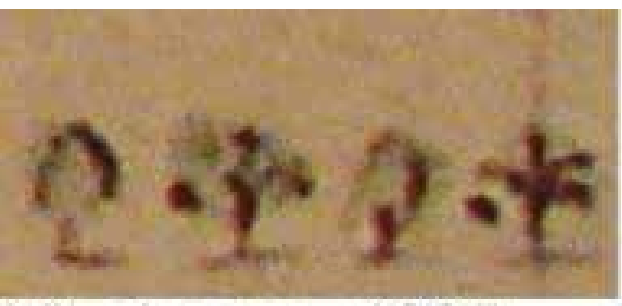

Vingboons, 1665

Fonte: Mapa de Olinda

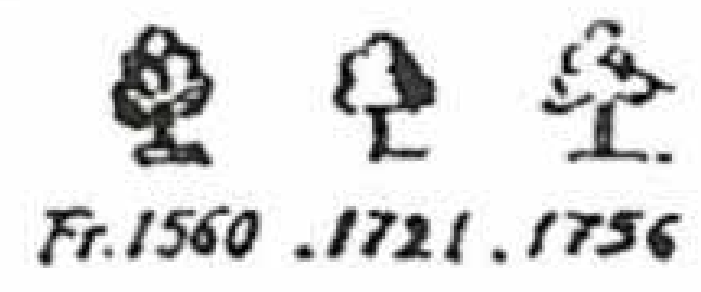

Fonte: DAINVILLE apud BUENO,2004, p.205.

Figura 15 - Comparação entre os ícones de árvores empregados por Vingboons para os quintais de Olinda e outros utilizados em cartografia de períodos anterior e posteriores. 
da arvore he de figura ovada mas pontuda [...] se lava de uma aguada de meia tinta de verde-bechiga, ou verde-lírio, e depois de da parte opposta da luz ${ }^{34}$.

Na representação dos quintais de Vingboons, existem arranjos que remetem aos pomares descritos por Fortes, pois aparecem como árvores organizadas em fileiras e espaçadas em intervalos iguais, e diferentes dos arvoredos. Estes últimos parecem referir-se as árvores em sua habitat natural, não subjugado à ordem de composição.

E em outra obra ao referir-se a quintais, hortas e jardins, Fortes comenta:

O vaõ das casas, e edifficios se póde lavar de huma meia tinta de carmim igual por toda a parte; [...] os quintaes, hortas, e jardins, que houver se devem notar as plantas, que se riscarão, e lavarão do modo, que adiante diremos [...]

As hortas se riscaõ com a regoa sobre o papel, sem a aguada clara dos montes, terras lavradas, a respeito da brancura, em que devem ficar os caminhos, fazendo os canteiros em paralelogramos desiguaes, ou quadrados, de sorte, que naõ affecte a regularidade dos jar$\operatorname{dins}^{35} \cdot[\ldots]$

O desenho dos jardins, quanto aos canteiros, naõ differem do desenho das hortas, se naõ na regularidade e simetria ${ }^{36}$.

Vale notar que, embora Fortes aconselhe uma distinção inicial entre os quintais, hortas e jardins, classificando-os enquanto unidades distintas, ele não se refere ao conteúdo e forma dos quintais.

quintal pode conter em seu espaço hortas e jardins, mas isto não os torna sinônimos, ou seja, os significados são distintos. Buscamos identificar, na confrontação entre o discurso textual e o imagético, as áreas citadas (Figura 16). As hortas (sombra lilás) representadas por quadriculas sem regularidade, e os jardins (verde) pelo desenho mais regular e simétrico. Há uma repetição sistemática dessas composições em quase todas as casas onde havia quintais.

Tal comparação permite inferir os quintais como espaços de múltiplos usos, do deleite nos jardins à utilidade das hortas. Veremos mais adiante que eles não se prestavam apenas para plantio, mas a várias outras atividades domésticas. Interessa-nos, neste momento, destacar que, na imagem holandesa, os quintais de Olinda são representados como se tomados totalmente por atividades produtivas e de plantio, sempre desenhados com formas determinadas, ou seja, quase uma ausência de áreas inutilizadas ou vazias. Já na História da Vida Privada no Brasil, Algranti caracteriza os quintais da seguinte forma:

Essas áreas destinadas ao convívio, ao cuidado dos animais e à indústria doméstica forneciam também produtos para a subsistência. Era das hortas e pomares que vinham muitas vezes alimentos básicos para a mesa dos colonos, uma vez que a economia colonial voltada para o exterior impunha cultura de certos produtos para o dia a dia. Árvores e plantas forneciam gordura vegetal para a cozinha e para os candeeiros, além de matéria-prima para as mezinhas caseiras. Nos quintais criavam-se também aves e porcos, e neles se instalavam galinheiros e currais ${ }^{37}$.
34. Idem, p. 218

35. Cf. Manoel de Azevedo Fortes (1722) apud Beatriz P. Siqueira Bueno (1998, p. 111).

36. Idem, p. 112

37. Cf. Leila Mezan Algranti (1997,p. 91-92); grifo nosso. 
Figura 16 - Identificação de áreas de pomar, hortas e jardins sobre o Mapa de Olinda (ca. 1665) do Atlas de Vingboons, elaborado pela autora a partir de referências existentes no Tratado... (1722) de Manoel de Azevedo Fortes.

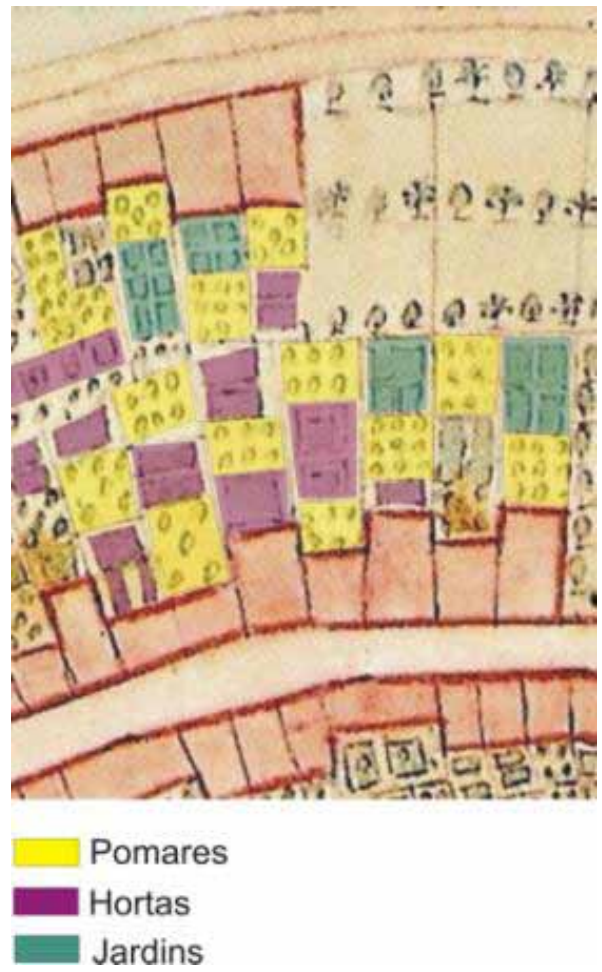

Diferente dos portugueses, os quintais despertaram nos holandeses uma extensa narrativa simbólica. $\bigcirc$ mosaico de signos representado no interior dos quintais está relacionado ao modo como os holandeses percebiam esses espaços. A tomada da vila exige dos invasores uma tentativa de adaptação aos componentes urbanos anteriormente construídos, conhecimento e domínio de suas partes. Desse modo, o mapa serve para revelar a vila, e permitir a reflexão e até servir de suporte para um futuro plano de ação. Os quintais, mais do que outro espaço urbano, são minuciosamente descritos, não a partir de uma análise individual de cunho científico, mas na tentativa de apreender suas formas, composições e inserção no tecido de Olinda.

No Mapa de Olinda não há distinção quanto à ocupação das ruas, não se verificando, por exemplo, ruas de serventia, que dão acesso aos fundos dos quintais. A distribuição das construções nos lotes e nas ruas se dá de modo uniforme. Embora os portugueses não tenham nos legado uma única planta da vila, sabemos, pela confrontação entre imagens e discursos, que a realidade se distinguia em parte da ocupação descrita pelos holandeses nesse mapa. Os quintais, em sua maioria, se apresentavam resguardados ao acesso direto do público, e esboçam espaços de privacidade junto à edificação.

No entanto, o estudo sobre a casa e o quintal depara-se com os limites impostos pela história da vida privada do Brasil. É quando há demanda por uma aproximação muito maior entre o arquiteto e o historiador, pois a distância temporal e a escassa informação impõe grandes desafios ao estudo deste objeto. 
A adaptabilidade portuguesa, festejada por Gilberto Freyre e identificada por este autor como presente em quase todas as ações lusitanas, constituiu, na colonização do Brasil, seu maior triunfo. Segundo o sociólogo:

A casa-grande de engenho que o colonizador começou, ainda no século XVI, a levantar no Brasil, grossas paredes de taipa ou de pedra e cal, cobertas de palha ou de telha-vã, alpendre na frente e nos lados, telhados caídos em um máximo de proteção contra o sol forte e as chuvas tropicais - não foi nenhuma reprodução das casas portuguesas, mas uma expressão nova, correspondendo ao nosso ambiente físico e a uma fase surpreendente, inesperada, do imperialismo português [...]. Desde esse momento que o português [...] tornou-se luso-brasileiro; o fundador de uma nova ordem econômica e social; o Criador de um novo tipo de habitação ${ }^{38}$.

De certo que as primeiras casas brasileiras nascem acompanhadas pela necessidade de adequar-se às diversas situações encontradas, seja em relação às questões geográficas, climáticas, culturais ou econômicas, seja em relação à mão de obra ou materiais construtivos. Existe, de fato, uma facilidade por parte dos colonizadores à adaptação, e esta característica favorece o surgimento de novas soluções. Porém tal arquitetura não é órfã. Os portugueses trazem consigo experiências, tradições, costumes, desejos e, acima tudo, a memória da própria casa.

A arquitetura das casas, mesmo com as dificuldades impostas pelas circunstâncias, deveria responder aos anseios dessa sociedade em formação e bem relacionada com outras partes do Reino. Produtos de luxo que, chegando à colônia, confraternizavam, por exemplo, na cozinha, com os frutos, animais e alimentos nativos aceitos pelos portugueses. A cozinha, assim como a arquitetura em geral, deixa de ser unicamente lusitana para incorporar novos modos de produzir.

O ciclo de produção alimentar, por exemplo, percorre dois espaços determinados da casa: o quintal e a cozinha, que muitas vezes se fundem em um só. Ao tratar sobre as casas do século XIX, Algranti comenta: "Isso sem falar nas varandas que se abriam para o quintal, onde o movimento e burburinho das atividades era incessante" ${ }^{\prime 39}$. Esse espaço, quando não havia a cozinha anexa à casa, assumia a função de intermediar as relações entre a casa e o quintal.

As referências sobre o quintal demonstram ser diferentes das da rua, opostas e complementares e, assim como o trajar domiciliar, dispensam todas as formalidades. Lugar onde a maioria das atividades é relacionada à vida em seu sentido mais necessário. As regras, quando existem, são definidas pelo cotidiano e pela praticidade.

Além da questão da subsistência, o quintal participa da vida familiar e comunitária de outras formas. Nas Denunciações do Santo Ofício de Pernambuco, de 1593 a 1595, há testemunhas que incriminam Branca Dias, cristã nova, habitante da vila de Olinda, de suas práticas judias, mas nesse ensejo revelam algumas atividades domésticas e sua espacialização no quintal.
38. Cf. Gilberto Freyre (2005, p. 35-36); grifo nosso.

39. Cf. Leila Mezan Algranti (1997, p. 97); grifo nosso. 
40. Cf. DENUNCIAÇÕES (1929, p. 44); grifo nosso.

41. Cf. Raphael Bluteau, s.v. FOLGAR (1712, p. 158)

42. Cf. DENUNCIAÇÕES (1929, p. 181); grifo nosso.

43. Cf. Leila Mezan Algranti (1997, p. 92).
Isabel Fragoso denuncia Branca Dias, suas filhas e outras pessoas:

E nos ditos sabbados se fechavão a ditta Branca Dias com as dittas suas filhas todo o dia pela menhaã até á noite, e não trabalhavão, e mãodavão as moças que aprendiam pêra suas casas nos dittos sabbados e algumas vezes as mãodavão pêra hum quintal a folgar, outros si vio que as dittas Branca Dias e suas filhas trabalhavão nos domingos em todo o ditto tempo que em sua casa esteve abrindo algodão e fiando e fazendo outros serviços assim como nos dias da semana toda mais ${ }^{40}$.

quintal é representado como um espaço também de lazer, onde se poderia folgar. Segundo Bluteau, folgar significa "Recrearse"4l, e este caráter recreativo, portanto, insinua que no quintal deveria haver espaço para tal atividade ou, ao menos, que habilitasse a este uso. Isabel relata, inclusive, outras atividades domésticas desenvolvidas pelas mulheres, como abrir algodão, fiar e outros serviços.

Ainda nas denunciações sobre Branca Dias, a mameluca Isabel de Lamas, também denunciante, confessa:

Ho dito Bento Dias estarão na ditta casa per grande espaço de tempo as vezes pellas manhaãs, e as vezes depois de jantar com as portas fechadas por dentro e entretanto assim estarão andavão as moças pequenas assim filhas da mesma Branca Dias com outras de fora que vinhão aprender e lavrar folgando no quintal das mesmas casas pera onde a ditta Branca Dias thes mãodarão que fossem lavrar e folgar na ditta ora e tempo em quanto estavão fechados como ditto he ${ }^{42}$.

$\bigcirc$ destaque dado às "portas fechadas por dentro" indica que essa atitude não deveria ser comum durante o dia, revelando, portanto, um ritual diferente dos hábitos comuns dos cristãos e moradores de Olinda. Por outro lado, quando sua vida é comum, fica evidente que o quintal também servia a fins pedagógicos; o ensino também era uma atividade doméstica corriqueira no período colonial e se estendia algumas vezes até o quintal. Este acolhia o ensino e a prática do oficio, ao mesmo tempo em que era absorvido como parte do espaço social feminino. Um segmento da população extremamente importante para a vida na colônia, pois quase todas as atividades domésticas estavam a cargo da mulher - portuguesa, nativa ou negra - seja na execução ou na supervisão.

Mas os quintais quinhentistas e seiscentistas possivelmente não eram áreas livres de edificações, teriam pequenas estruturas que auxiliavam nas tarefas do dia a dia, como as encontrados no século XIX. Alguns telheiros simples e rústicos, outros melhor edificados, abrigavam a casa da farinha, o monjolo ou a moenda. Serviam também para guardar utensílios e alimentos de toda espécie, e era nessas dependências de trabalho que passavam boa parte do tempo, principalmente as mulheres da casa ${ }^{43}$.

Nos quintais deveria haver essas pequenas construções, em geral cobertas de palha, de execução bastante inferior à da edificação principal, onde 
ocorreriam atividades complementares à casa e, por esse motivo, chamadas de anexos, o que poderia ser um pequeno quarto para os escravos ou, ainda, um depósito, ou abrigo para os cavalos.

Além das áreas de serviço, o quintal podia conter a senzala e a secreta. Esta última era uma edificação com fins de higiene existente em algumas casas, mas que consistia muitas vezes apenas num buraco na terra, embaixo do qual podiam se instalar os chiqueiros. [...] $\mathrm{Na}$ maioria das vezes, todavia, era o urinol e os potes ou tigres que recebiam os excrementos, esvaziados depois pelos escravos, nas praias ou nos terrenos distantes ${ }^{44}$.

Nos primeiros anos do período colonial as preocupações sanitárias eram mínimas, tendo como principal atenção deslocar os depósitos fecais para fora do corpo da edificação, nos fundos do terreno ${ }^{45}$. Essa prática de fazer as necessidades longe da moradia era também um hábito dos nativos. "Dos indígenas parece ter ficado no brasileiro rural ou semi-rural o hábito de defecar longe de casa; em geral no meio de touça de bananeiras perto do rio"46.

Nas cidades medievais portuguesas, Amélia Aguiar Andrade comenta que existiam esterqueiras situadas nas periferias urbanas para depósito desses materiais. "Para essas periferias podiam ainda empurrar-se as esterqueiras, esses terrenos abertos onde as populações urbanas iam fazer seus despejos, sobretudo aquelas que não podiam recorrer à horta das traseiras da casa para este fim" ${ }^{\prime \prime}$. Os fundos dos quintais também serviam para tal fim - uma espécie de monturo.

A necessidade de despejo desses materiais justifica em grande parte a existência das ruas de serventia, por permitirem a saída e entradas dos tigres. Sabe-se também que um dos principais meios de transporte na colônia eram os cavalos e estes também precisavam pousar próximo à casa. Logo, era necessário ter uma estrebaria mínima e, de acordo com a apropriação do lote, que não permitia outras áreas livres que não fossem os quintais, seu lugar seria atrás das casas. Os cavalos deveriam compartilhar o mesmo acesso que os tigres.

Tais práticas também alcançariam o século XIX. É o que confirma o depoimento de Vauthier:

Assim, o cavalo é auxiliar indispensável do brasileiro que se preza e toda casa bem posta tem a sua cocheira, colocada sempre, como esta, a um ângulo do pátio [quintal] e aberta a todos os ventos. Quanto a cisterna que vemos também no pátio, disposta a servir duas casas contíguas, é um traço característico da cidade de Pernambuco e daquelas que, construídas, embora, em praias arenosas e na vizinhança do oceano, filtram constantemente águas doces subterrâneas, que se encontram a alguns metros de profundidade ${ }^{48}$.

Diferente das edificações, as subdivisões dos quintais muitas vezes não eram rígidas em seus limites internos que, por exemplo, definiam o espaço da horta e o da circulação. Muitos dos animais eram criados soltos, ao modo "natural", o que não significa que não houvesse uma aptidão de uso para determinadas áreas. A ausência de limites de fundo em alguns quintais parece indicar uma espécie de simbiose com a paisagem circundante.
44. Idem, p. 95; grifo nosso.

45. O costume de despejar os resíduos no quintal não parece ser característica apenas portuguesa. "Foram feitas algumas tentativas para melhorar a situação [de saneamento] e, a partir do século XVI, uma ordem da cidade de Paris exigia que todas as casas fossem equipadas com uma latrina que desembocasse em uma fossa subterrânea no quintal". Cf. Wiltold Rybczynski (2002, p. 49-50); grifo nosso.

46. Cf. Gilberto Freyre (2005, p. 182).

47. Cf.Amélia Aguiar Andrade (2003, p. 35); grifo nosso.

48. Cf. Louis Léger Vauthier (1975, p. 43). 
49. Cf. Raphael Bluteau, s. v. QUINTA $(1712$, v. 7, p. 65).

50. Idem, s.v. QUINTAL (1712, v. 7, p. 65).
Enquanto espaço urbano e, portanto, palco de representação, os quintais absorveram as mudanças e reconstruíram-se, assim como os outros espaços domésticos, a partir de uma nova concepção que considera as influências do lugar.

Esse momento delicado da história marca alterações nos costumes portugueses, que vão caracterizar o modo de ser e viver brasileiro e, consequentemente, a arquitetura, também em uma outra dimensão, a do preenchimento dos quintais com vegetação. A escolha das espécies que passaram a fazer parte deste cenário urbano, em especial nos quintais, constituem a resposta a uma gama de valores influenciados pelo contexto da expansão ultramarina e das descobertas daí decorrentes.

Os quintais como espaço de (re)produção

Embora os quintais não fossem assunto relevante para os cronistas do século XVI e XVII, eles surgem nos relatos como espaços relativos à produção em atividades cotidianas das habitações e na subsistência dos moradores. A eles somam-se as cercas dos conventos, mosteiros e colégios, essas mais citadas pelo fato de muito desses escritores serem religiosos e por ser informação vinculada à expressão religiosa da vila.

Os quintais também estão relacionados à reprodução de práticas tradicionais, herdadas principalmente dos costumes lusitanos, mas também dos modos de fazer indígenas. A influência do colonizador torna-se significativa não apenas em suas características, mas também pela etimologia do nome, que nos remete às quintas e quintais portugueses.

Contudo, há diferenças entre os dois termos e, antes de tudo, é preciso contextualizá-los no tempo e espaço. Segundo Raphael Bluteau, a "quinta" se definia como: "Casa de campo, ou fazenda, de lavoura no campo com sua casaria. Chamou-se assim porque de ordinario o que arrenda a Quinta, dá ao dono della a quinta parte do que colhe de fructos" 49 . Ou seja, a quinta tem um caráter rural, semelhante ao das nossas chácaras e sítios. Os quintais por sua vez eram definidos da seguinte forma:

Quintal he na cidade, ou villa, hu pedaço de chaõ, com árvores fructiferas \& cerca de muros. Chama de Quintal por servir como de Quinta no povoado. Nas casas religiosas chama-se cerca. Naõ he fácil acharlhe nome proprio Latino, porque Hortus he jardim, Hortus oitorius he Horta, Pomarium he Pomar, como tambem Vividarium, \& propriamente fallando, Quintal, não he jardim, nem horta, nem pomar. Mas a necessidade no obriga a usar Vividarium ou Pomarium, \& sendo preciso se the poderá acrescentar, Muro septum ${ }^{50}$.

Logo, o quintal também está relacionado ao cultivo e à casa, nascido para "servir como de Quinta no povoado". É, porém, espaço por excelência 
urbano, delimitado e com funções que não se restringem apenas ao plantio. Como a quinta, o quintal está vinculado a uma casa, portanto à produção doméstica. Como cita Bluteau, o quintal não é jardim, nem horta, nem pomar, porém, assim como a cerca dos religiosos, absorve, de modo às vezes segmentado, mais de uma dessas apropriações.

A dificuldade de Bluteau de achar correspondente latino denuncia a semelhança funcional entre esses termos, certamente com características comuns, com as hortas, hortos, pomares e jardins. Por outro lado, a complexidade dessa definição pode estar amparada pelo caráter livre de sua composição e por ser um espaço bastante relacionado ao cotidiano familiar. Uma aparente fluidez e a liberdade na apropriação desses espaços contrastam com as regras cristãs para os espaços públicos.

Em suas linhas, Olinda guarda influências da tradição e dos costumes lusitanos, entretanto, sabe-se que estes tiveram que sofrer ajustes para se adequar à nova realidade. E foi a partir desta necessidade, juntamente com a possibilidade de fazer algo novo longe da metrópole, que determinados elementos urbanos ganharam diferentes concepções no Novo Mundo.

Assim, não se pode pensar que os quintais olindenses tivessem guardado a mesma aparência e composição dos portugueses, a começar pelas diferenças climáticas, topográficas e temporais, entre outras. Por haver neles áreas de plantio, definidas pelo tipo das espécies cultivadas, e estas foram aqui bastante modificadas. E, como se pode observar em Bluteau, os portugueses não possuíam minimamente um modelo ou padrão para quintal.

Sabe-se, portanto, que seriam áreas estreitamente relacionadas com a subsistência, ou seja, com o fornecimento de produtos para a alimentação e suporte das atividades domésticas, mesmo quando estas não aparecem nos relatos de modo distinto e definido no espaço. Com relação à cerca, esta pluralidade aparece, por exemplo, nas notícias do padre jesuíta Doutor Torres, em carta de 10 de junho de 1562, proveniente do Espírito Santo, em que relaciona, inclusive, a proximidade entre o cultivo e a produção:

Um dos Irmãos é coadjuntor temporal; não sabe ler nem escrever; homem de meia idade, manso e humilde e prompto na obediência, serve commumente de cozinheiro e hortelão, trata com muitos amos aos Irmãos, tem muitos legumes e fructas em seu pomar, especialmente a que chamam de bananas, que duram todo o anno e são grande ajuda para a sustentação desta casa ${ }^{51}$.

Nota-se a sobreposição de atividades distintas, cozinhar e cultivar, produzidas de modo complementar, pelo mesmo indivíduo, o que não deve constituir regra, mas mostra a existência do vínculo entre ambas. De outro modo, não faz distinção entre o cultivo da horta e do pomar, tratando-os quase como sinônimos, "cozinheiro e hortelão, trata [...] em seu pomar".

abastecimento alimentar é um assunto recorrente nos registros dos primeiros anos do Brasil, pois não era possível garantir a subsistência da 
52. Idem (1988a, p. 204); grifo nosso.

53. Cf. Gilberto Freyre (2005, p. 72).

54. Ver Frei Christovão de Lisboa (1625-1631). Fonte gentilmente indicada e fornecida por Alexandre Alves Dias, do Arquivo Público de Olinda, que participou do Projeto Resgate no Arquivo Histórico Ultramarino.

55. O livro se divide em 3 partes, a primeiras é relativa aos peixes, um inventário das espécies até então conhecidas (ex.:Acaracoro,Amoreta Camurym, Mandi etc). A segunda se refere aos animais (ex.: Bugio, Capivara, Machacha, Prigrissa etc); a terceira às aves (ex.:Acara, Arara, Hema, Jaburu etc); e a quarta às árvores (ex.:Ananás, Cara, Mandioqua, Mamoeiro, Mangaba, jinipapo etc). Todas as espécies são identificadas por nome, cuja maioria parece ter origem indígena; $\mathrm{e}$ por desenhos que comunicam seu aspecto exterior; Ver Frei Christovão de Lisboa (1625-1631)

56. Cf. Afrânio Peixoto (1988a, p.170) população valendo-se apenas de mantimentos trazidos da metrópole. $\bigcirc$ custo, a distância e a irregularidade do transporte desencorajava essa prática e estimulava a população a construir sua própria rede de abastecimento.

A questão dos mantimentos era uma das primeiras preocupações dos colonizadores, seja em Olinda, Salvador, São Vicente etc. Nos primeiros anos, o abastecimento de produtos para a alimentação deveria ser muito dependente da produção da unidade residencial, seja nos quintais das casas ou nas cercas dos conventos, embora se contasse com as roças e os plantios nos engenhos.

Mesmo alguns anos depois da fundação da Vila de Olinda, quando nela já havia um comércio e abastecimento bem desenvolvidos - e também na Bahia e em São Vicente -, Nóbrega escreve ao rei D. João, em 1552, relatando a necessidade que tem do trabalho dos gentios para a produção de mantimentos:

Na conversão do gentio nos ajudou muito, porque fez logo ajuntar quatro ou cinco aldeias que estavam derredor da cidade, em uma povoação junto ao Rio Vermelho, onde pareceu mais conveniente, para que toda essa gente pudesse aproveitar-se das roças e mantimentos que tinham feito, e aqui mandou fazer uma igreja grande, em que coubesse toda a gente, a que chamam São Paulo52.

Paralelo ao conhecimento adquirido na América, somavam-se as constantes permutas entre os povos colonizados, das ithas e do Oriente. "Outra circunstância ou condição favoreceu o português, tanto quanto a miscibilidade e a mobilidade, na conquista de terras e no domínio de povos tropicais: a aclimatabilidade" 153 . Podemos citar também que, nesse movimento, os portugueses promovem, por exemplo, um intenso intercâmbio entre as espécies cultivadas, onde muitas foram trazidas de lugares distantes e aclimatadas, diminuindo as fronteiras das colônias.

No período colonial, era comum a criação de determinados animais no perímetro doméstico, e, na tentativa de elencar algumas espécies possivelmente existentes nos quintais, foram reunidos fragmentos textuais a partir da pesquisa nos relatos de vários cronistas. Com tais informações, buscamos relacionar as espécies apresentadas, por exemplo, na obra de Christovão Lisboa intitulada Historia dos animaes e arvores do Maranhão. Pelo muito Reverendo Padre F. Christovão de Lisboa calificador do Santo Officio, e fundador da Custodia do Maranhão da Recolecção de Santo Antônio de Lisboa ${ }^{54}$, escrita provavelmente entre 1625 e 1631, logo, anterior ao período nassoviano. $\bigcirc$ estudo revela 0 interesse dos portugueses pelo conhecimento das espécies animais e vegetais encontradas em solo maranhense. Sabe-se, porém, que tais espécies não são apenas maranhenses, mas existem em quase todo o Nordeste ${ }^{55}$. Dessa obra, foram selecionadas algumas imagens para acompanhar este nosso trabalho.

Durante os primeiros anos, muitos dos animais que faziam parte do cenário europeu foram trazidos para o território conquistado. Na carta do Padre Nóbrega para o Provincial em Portugal, em 1557, se lê: "No fim de julho (1557) chegou aqui uma caravella d'El Rei que trazia gado"56. Gabriel Soares de Sousa 
refere-se à trajetória que esses animais faziam nas colônias do Império Português: "As primeiras vacas que foram à Bahia levaram-nas de Cabo Verde e depois de Pernambuco, as quais se dão de feição que parem cada ano e não deixam nunca de parir por velhas" 57 .

Quando da permanência dos jesuítas no Brasil, a carência de mantimentos foi um dos principais temas tratados em suas cartas. A princípio, os mantimentos ficavam a cargo de gentios convertidos, que se encarregavam de trazê-los de sua plantação de mandioca (as roças) e dos matos - frutas, víveres, pescados etc. No final do século XVII, o padre Aires de Casal nos lembra que não fazia parte da cultura indígena o cultivo de espécies ao modo europeu ${ }^{58}$; e, no século XX, Gilberto Freyre complementa: "Os animais domésticos entre os indígenas quase eram simplesmente para fazer companhia à pessoa e não para servi-la nem fornecer-the alimento" 59 . Com a introdução de outras práticas, há uma mudança de comportamento entre os gentios da província de Pernambuco:

Todas errantes, sem conhecimento de gênero algum de agricultura, mantendo-se de frutas silvestres, mel, e caça: um porco, um veado, um pássaro tudo era assado com cabelo, pena e intestinos Todos receberam o batismo; e depois de aldeados começaram a cultivar os víveres mais necessários à vida, como mandioca, milho, abóboras, e algumas frutas: conservando uma grande paixão pela caça, e pretendendo ter o mesmo direito sobre os bois, e carneiros dos fazendeiros circunvizinhos: sem o qual sestro os cristãos da primitiva não teriam sido de costumes mais inocentes, segundo publicavam os catequistas ${ }^{60}$.

Frei Vicente do Salvador ressalta a importância dessas espécies na produção doméstica: "Criam-se no Brasil todos os animais domésticos e domáveis de Espanha, cavalos, vacas, porcos, ovelhas e cabras, e parem a dois e a três filhos de cada ventre, e a carne do porco se come indiferentemente de inverno e verão, e a dão a doentes como a de galinha"ol. E destaca, inclusive, uma nova relação que estes mesmos animais passam a ter na vida dos habitantes do Novo Mundo - a importância simbólica e cerimonial do consumo passa a sofrer transformações.

A introdução da criação doméstica desses animais foi de grande relevância para a construção da paisagem ${ }^{62}$. Mas não apenas pela tentativa de trazer consigo um determinado gosto ou modo de vida, mas por produzir, na população urbana em formação, um instante de ajuste na relação entre nativos e estrangeiros frente a determinadas questões. No mínimo, introduzir na paisagem - aparentemente indivisa - áreas de criatório que, no quintal, reorganizam seus limites.

Em relação aos animais, Frei Vicente do Salvador tratou de citar as espécies criadas, certamente nos quintais, para abastecimento do lar: "Além das aves que se criam em casa: galinhas, patos, pombos e perus, há no Brasil muitas galinhas bravas e umas aves chamadas jacus, que na feição e grandeza são todas como perus"63.
57. Cf. Gabriel Soares de Sousa (1971, p. 163); grifo nosso.

58. Cf. Manuel Aires de Casal (1976, p. 253).

59. Cf. Gilberto Freyre (2005, p. 166)

60. Cf. Manuel Aires de Casal, (1976, p. 253).

61. Cf. Frei Vicente do Salvador (1982, p.70).

62. A palavra "doméstico" implica numa relação direta com a casa, a vida familiar: "Diz-se do animal que vive ou é criado em casa"; cf Aurélio B. de H. Ferreira, s.v. DOMÉsTiCo (1986).

63. Cf. Frei Vicente do Salvador (1982, p.73) 
64. Idem, p.70; grifo nosso.

65. Cf. Fernão Cardim (1980, p. 56).

66. Idem, p. 27; grifo nosso
Logo os quintais das primeiras vilas portuguesas deveriam passar a abrigar uma diversidade maior de espécies, não apenas aclimatando as trazidas do exterior, mas acolhendo as nativas.

Um bom exemplo é a capivara: "Outros há o que chamam capiguaras, que quer dizer comedores de erva: andam sempre na água, tirado quando saem a pascer pelos vales e margens dos rios, e alguns tomam e criam em casa fora da água, pelo que se julgam por carne e não por pescado"64. Percebe-se a incorporação de espécies nativas no cenário doméstico, o que implica no trato diferenciado não apenas da criação, pois não eram porcos, mas também na forma de consumi-las, pois não demonstravam ter convicção se era "carne" ou "pescado" (Figura 17). Fernão Cardim as denomina Capijuara:

Destes porcos d'água ha muitos e são do mesmo tamanho dos porcos, mas differem nas feições; no céo da bocca têm pedra muito grossa que thes serve de dentes queixaes. Esta tem os Índios por jóia para os filhos e filhas; não têm rabo, andão muito tempo debaixo d'água, porém habitam na terra, e nella crião seus filhos; seu comer he ervas e fructas que ao longo dos rios achão ${ }^{65}$.

Nas proximidades da vila de Olinda, há referência ao rio das Capivaras - provavelmente foi assim denominado pelos nativos -, que originou o nome do rio que hoje é conhecido como Capibaribe.

Também o tatu foi citado por Cardim como animal doméstico: "A carne parece de gallinha, ou leitão, muito gostosa, das pelles fazem bolsa, e são muito galantes, e de dura; fazem-se domesticos e crião-se em casa"66. Ele denuncia a dificuldade de o capturarem, destacando sua habilidade em cavar buracos (Figura 18).

Gabriel Soares de Sousa, quando se refere aos animais do Brasil, destaca a anta como doméstica. "Se tomam estas antas pequenas, criam-se em casa, onde se fazem muito domésticas, e tão mansas que comem as espinhas, os
Figura 17 - Capivara gravura que ilustra o livro de Frei Christovão de Lisboa(1625-1631). Fonte: Projeto Resgate (1995).

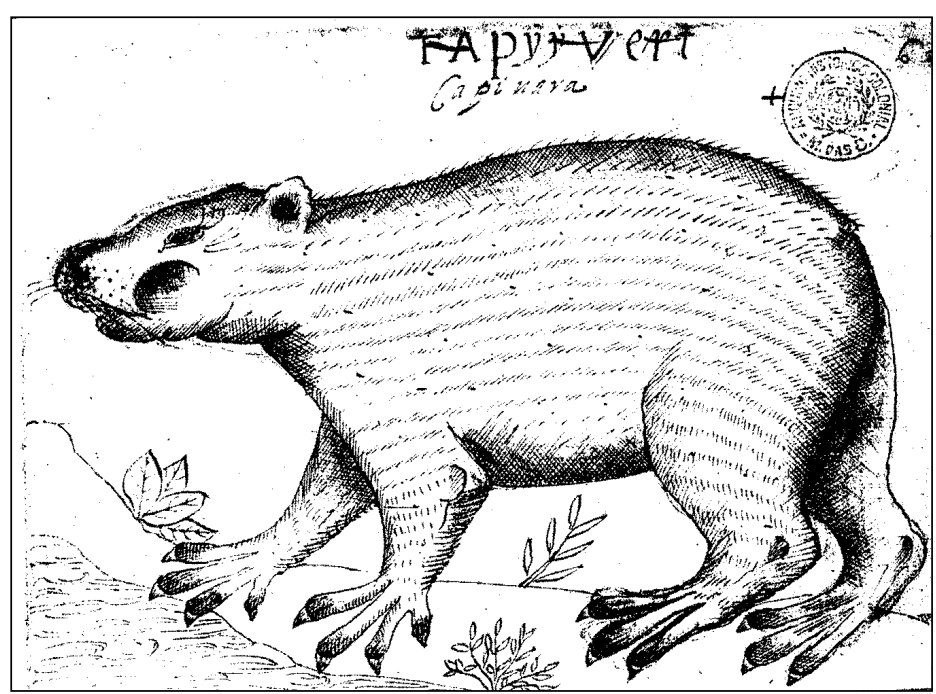




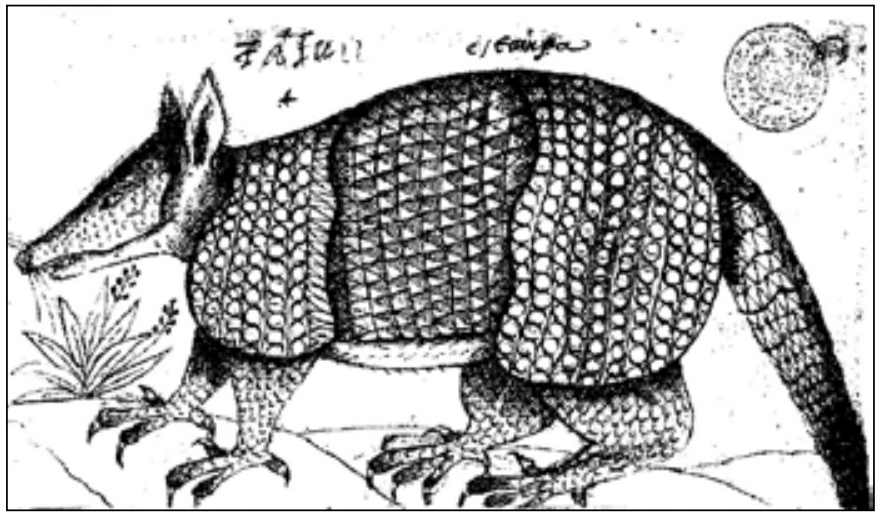

ossos, com os cachorros e gatos de mistura; e brincam todos juntos" 67 . Dentre as utilidades, ele revela que o animal tem boa carne e a pele faz boa couraça. E que os ossos, quando queimados, possuem propriedades terapêuticas.

Certamente o que fez os portugueses passar a consumir e criar determinados animais "exóticos" foi a influência do cardápio indígena, logicamente motivada pela necessidade, mas alcançada principalmente pela capacidade de adaptação portuguesa.

Ainda hoje, há muitas espécies vegetais que foram descritas pelos relatos dos viajantes como relacionadas à subsistência da colônia e cultivadas no quintal, cuja função era compartilhada com as cercas e roças. Pode-se supor que não provinham unicamente da colheita no campo e nem seu fornecimento era irregular, mas fazia-se seu cultivo em escalas diferenciadas, portanto, possivelmente também nos quintais.

Ao observarmos as descrições de Frei Vicente de Salvador e Fernão Cardim, por exemplo, percebemos que a relação dos colonizadores com os frutos da terra não se restringiu apenas à admiração. Experimentaram-nos e aprenderam suas propriedades, acrescentando-os às espécies de consumo cotidiano. Além de alimento, eram recorrentemente citados por suas versatilidades funcionais, servindo também, além de remédio, para construção e como matéria-prima para utensílios domésticos, industriais e de transporte.

Do universo vegetal, podemos discorrer sobre algumas espécies que se destacaram por sua inserção na vida colonial, dentre elas a mandioca, extensamente citada nos discursos dos séculos XVI e XVII como principal alimento do Novo Mundo português.

A mandioca é também um dos temas da gravura holandesa denominada Pernambuco (Figura 19). Nesta imagem está reportada a base da economia agroexportadora e da subsistência da colônia: a produção, em suas etapas, do açúcar e da farinha mandioca. Esta última consistiu, por longo período, uma das principais fontes alimentícias da colônia, sendo considerada por muitos o pão da terra. Nessa mesma gravura estão representados produtos de consumo
67. Cf. Gabriel Soares de Sousa $(1971$, p. 244) 

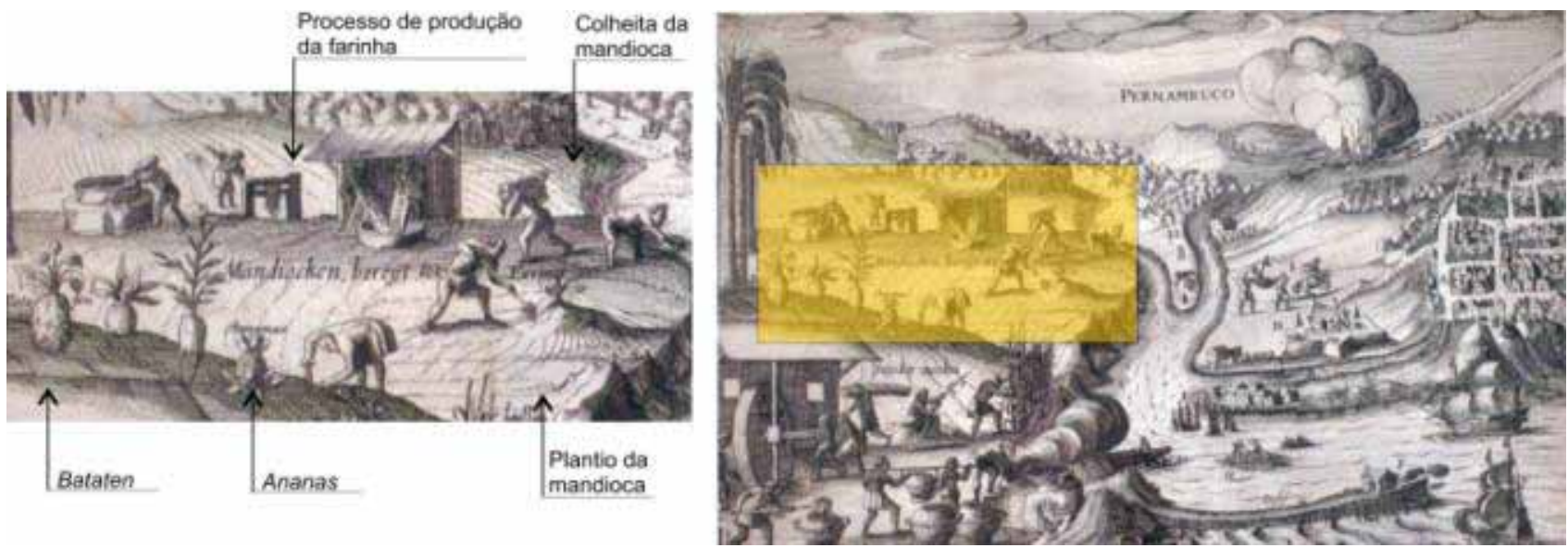

Figura 19 - Registros da produção voltada a subsistência. Tratamento infográfico feito pela autora sobre a gravura Pernambuco existente em Reys-boeck va het rijcke Brasilien... [Livro de viagem...] (1624), de N. G. [?]. Fonte da imagem: Nestor Goulart Reis Filho (2000).

68. Cf. Francisco Augusto Pereira da Costa (1983, v. 6, p. 397).

69. Cf. Gaspar Barléu (1974, p. 72).

70. Cf. Francisco Augusto Pereira da Costa (1983, v. 6 , p. 397).

71. Cf. PROJETO Foral (2000, p. 16-17); grifo nosso. local, como palmeiras (lado esquerdo), Annanas e Bataten (os desenhos destes últimos, assim denominados).

Durante o período de ocupação de Pernambuco, os holandeses começaram a dar importância à cultura da mandioca, pois constituía um dos principais gêneros alimentícios da população e, mais tarde, deles próprios. $\mathrm{Na}$ expedição científica de Nassau, Piso e Marcgrave estudaram minuciosamente a espécie, particularizando-a, analisando sua produção e virtudes medicinais. Em edital de 15 de abril de 1640, os holandeses chegaram a impor seu cultivo, ficando todos os moradores obrigados a plantar trezentas covas de mandioca por cada peça de trabalho (negro ou negra) que tivessem na propriedade ${ }^{68}$.

O plantio da mandioca era feito em "roças". Segundo Barléu, "os portugueses chamam 'roça" aos campos que a dão, e aos agricultores designam com 0 nome de "lavradores" e de "roceiros" 69 . Ao que parece, a roça tem antepassado indígena, sendo herdeira da mandiotuba ${ }^{70}$, que seria a plantação de mandioca, geralmente em uma área mais afastada da aldeia. Desde o início da Vila, tal tipo de cultivo foi trazido para os arredores do núcleo urbano.

Na Carta Foral lê-se: "E as reboleiras de matos para roças a quem o concelho as arrendar"; e, mais adiante, "até onde faz um esteiro que está detrás da roça de Bras Pires, conjunta com outra de Rodrigues Alvares"7l, fazendo citação explícita de alguns proprietários de roças. Há a possibilidade de ter a mandioca sido cultivada, em menor escala também nos quintais - ainda hoje é costume em algumas cidades interioranas -, onde os moradores têm pequenas plantações. Pereira da Costa reforça a importância desse cultivo que se estende ao longo do tempo. Ele cita:

Bando do governador José César de Menezes, ordenando aos corregedores da comarca e câmaras respectivamente, que à vista da redução e decadência da cultura da mandioca, e 
de conformidade com a ordem régia de 27 de fevereiro de 1701, promovessem e ativassem a cultura desse importante gênero de primeira necessidade a alimentação pública ${ }^{72}$.

Pelo próprio nome, que a define como utilíssima, a Manihot utilíssima entra definitivamente no cardápio brasileiro. Segundo Câmara Cascudo, "A farinha [de mandioca] é o primeiro conduto alimentar brasileiro pela extensão e continuidade nacional, com o beiju e a carimã consolidam a prestigiosa presença da mandioca"73. Dos produtos derivados da sua farinha e ainda presentes até hoje na cultura brasileira, poderíamos ainda citar a tapioca, a manicueira, o molho tucupi e a manisaua (maniçoba).

As palmáceas são outra espécie recorrente nas imagens e relatos sobre as paisagens urbanas coloniais. Aparecem representadas em várias imagens da Vila de Olinda, em especial nas vistas. Também compõem o livro do Frei Christovão de Lisboa (Figura 20), onde a inajá (espécie de palmeira) aparece com o nome de "Inaya", com o seguinte comentário: "deste palmo saem os melhores palmitos"74.

Segundo Frei Vicente do Salvador, "Há muitas castas de palmeiras, de que se comem palmitos e o fruto, que são uns cachos de cocos, e se faz deles azeite para comer e para candeia, e das palmas se cobrem as casas"75. Logo se percebe que as palmáceas foram incorporadas na vida da colônia de várias formas. As mais destacadas são para cobertura das primeiras casas, ao modo indígena, que também as utilizavam para construção.
72. Cf. Francisco Augusto Pereira da Costa (1983, v. 6, p. 397).

73. Cf. Luís da Câmara Cascudo (2004, p. 96).

74. Cf. Microfilme 0552, Inventário Alberto Iria (1960).

75. Cf. Frei Vicente do Salvador (1982, p.64)

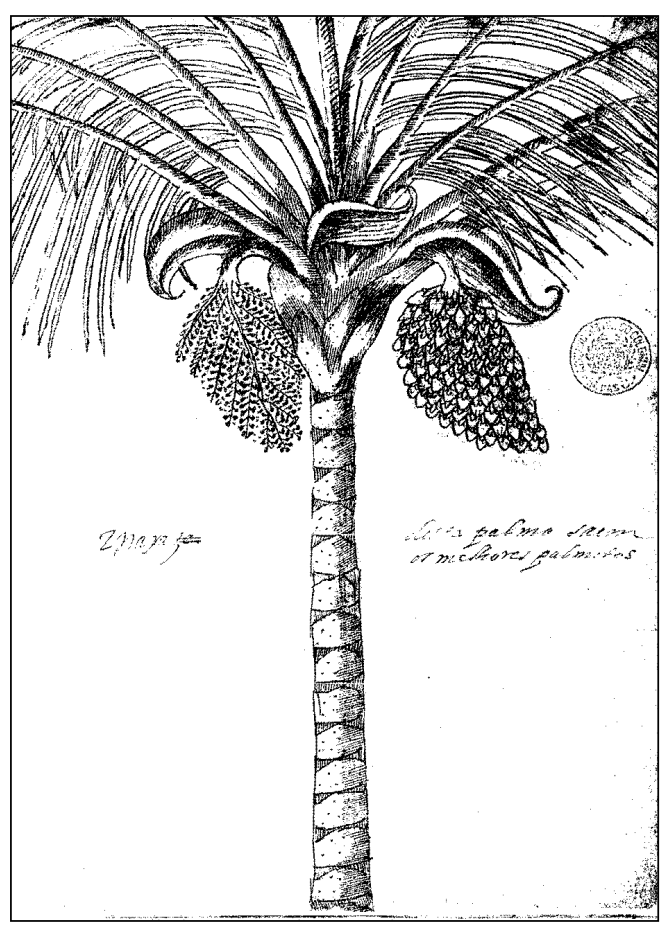

Figura 20 - Inaya [Inajá], com a inscrição "deste palmo saem os meIhores palmitos" gravura que ilustra o livro de Frei Christovão de Lisboa(1625-1631). Fonte: Projeto Resgate (1995). 
76. Cf. Gabriel Soares de Sousa (1971, p. 137)

77. Idem, p. 138; grifo nosso.

78. Antonio Blasquez, apud Afrânio Peixoto (1988b, p. 343); grifo nosso.
Geralmente eram materiais para construções de natureza efêmera - por exemplo, para cobrir estruturas de menor importância, como os anexos das edificações - pois, devido ao próprio desgaste, precisam ser renovadas periodicamente.

Eram espécies que também se cultivavam nos quintais, como relata Gabriel Soares de Sousa acerca da Bahia: "[As] casas de moradores com seus quintais, os quais estão povoados de palmeiras carregadas de cocos e outras de tâmaras, e de laranjeiras e outras árvores de espinho, figueiras, romeiras e parreiras"76. E mais adiante, ao se referir a paisagem da Bahia, destaca com precisão as espécies plantadas nos quintais:

A vista desta cidade é mui aprazível ao longe, por estarem as casas com os quintais cheios de árvores, a saber: de palmeiras, que aparecem por cima dos telhados; e de laranjeiras, que todo o ano estão carregadas de laranjas, cuja vista de longe é mui alegre, especialmente do mar, por a cidade se estender muito ao longo dele, neste alto ${ }^{77}$.

As palmáceas eram utilizadas não só como alimento, substituindo o azeite português, mas também como combustível para o candeeiro e suas folhas para a ornamentação das ruas em dias de procissão ou outras festividades religiosas e públicas, "o que primeiro se fez foi uma procissão logo pela manhã, estando ornadas de palmeiras as ruas"78.

Podemos destacar várias frutas exóticas aos portugueses, mas muito apreciadas aqui e incorporadas ao cardápio lusitano, como é o caso do caju (Figura 21). Fernão Cardim descreve o cajueiro com o nome de Acaju e destaca as infinitas formas de se aproveitar dele:
Figura 21 - Caiu [Caju] gravura que ilustra o livro de Frei Christovão de Lisboa(1625-1631). Fonte: Projeto Resgate (1995).

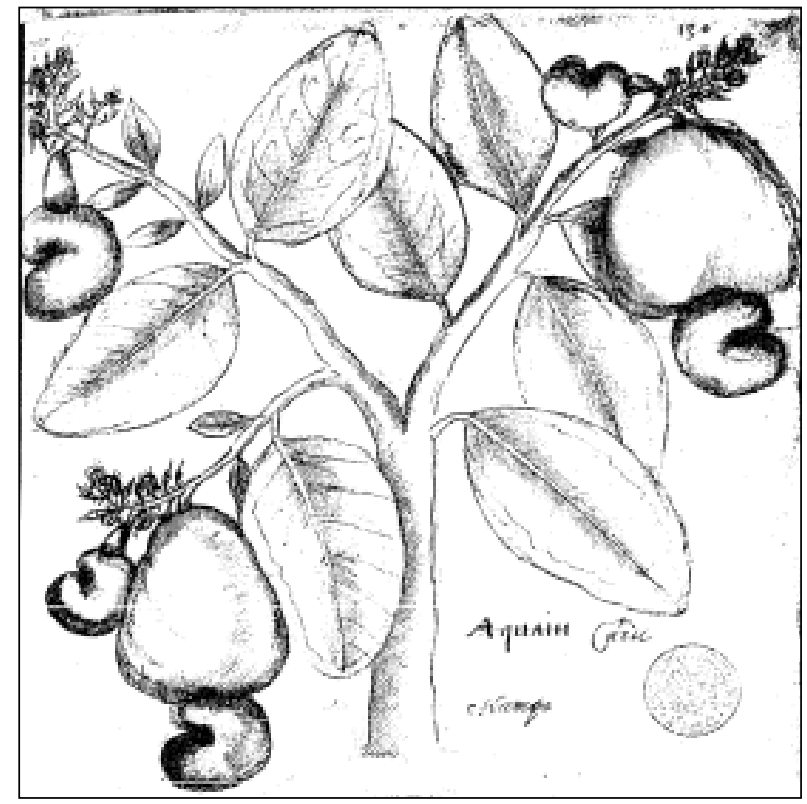


A castanha he tão boa, e melhor que as de Portugal; comem-se assadas, e cruas deitadas em água como amêndoas piladas, e dellas fazem maçapães, e bocados doces com amendoas. A madeira desta árvore serve pouco ainda para o fogo, deita de si goma boa para pintar, e escrever em muita abundãncia. Com a casca tingem o fiado, e as cuias que the servem de panellas. Esta pizada e cozida com algum cobre até se rasgar a terça d'agua, he único remédio para chagas velhas e sárão depressa [... . Destes acajus fazem os índios vinho79.

Outra fruta muito apreciada pelos portugueses era o maracujá (Figura 22). Sobre a disposição deste cultivo nos quintais da Bahia, Gabriel Soares de Sousa comenta:

Dos maracujás, que é uma rama como hera e tem a folha da mesma feição, a qual atrepa pelas árvores e as cobre todas, do que se fazem nos quintais ramadas muito frescas, porque duram sem se secar, muitos anos. A folha da erva é muito fria e boa para desafogar, pondo-se em cima de qualquer nascida ou chaga e tem outras muitas virtudes; e dá uma flor branca muito formosa e grande que cheira muito bem, de onde nascem umas frutas como laranjas pequenas, [...] e tudo o que tem dentro se come, que além de ter bom cheiro tem suave sabor ${ }^{80}$.

Tempos depois, Aires do Casal cita várias outras espécies nativas incorporadas à paisagem urbana colonial, dentre elas, o umbuzeiro, o juazeiro,
79. Cf. Fernão Cardim (1980, p. 35).

80. Cf. Gabriel Soares de Sousa (1971, p. 199); grifo nosso.

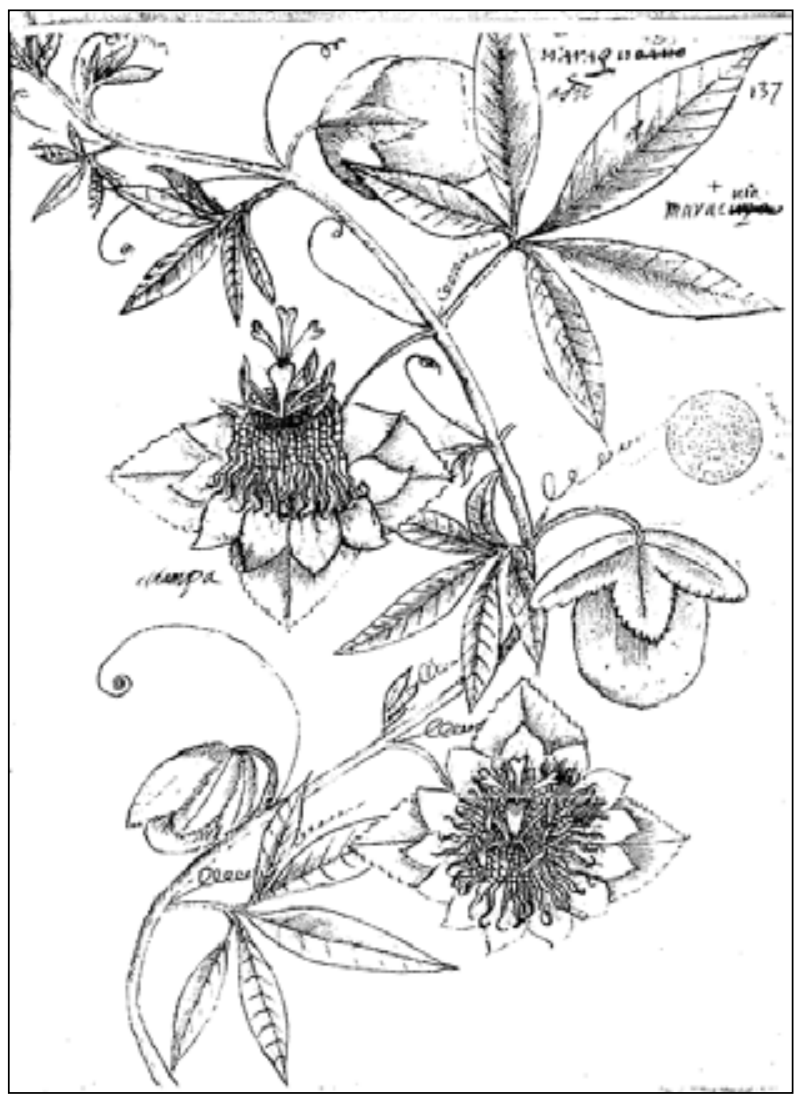

Figura 22 - Maracuia hi [Maracujá] gravura que ilustra o livro de Frei Christovão de Lisboa(1625-1631). Fonte: Projeto Resgate (1995). 
81. Cf. Frei Vicente do Salvador (1982, p. 68); grifo nosso.

82. Cf. Gabriel Soares de Sousa (1971, p. 203)

83. Cf. Frei Vicente do Salvador (1982, p. 65).

84. Cf. Gabriel Soares de Sousa (1971, p. 206); grifo nosso.

85. "Pelos mesmos campos se criam outras ervas, a que o gentio chama caapiá, e os portugueses malvaísco, porque não em outra diferença do de Portugal que ser muito viçoso."; Cf. Gabriel Soares de Sousa (1971, p. 210). a jabuticabeira, a mangabeira, o jenipapeiro, o murici, o urucu, a barriguda, as caneleiras, o pau-brasil, o mangue, o pequi, a pindaíba, o vinhático etc., muitas delas presentes nos quintais até os dias atuais.

As referencias sobre as espécies nativas geralmente vinham acompanhadas da descoberta de alguma função terapêutica. Alguns médicos, tempos mais tarde, não só acreditavam como receitavam esses remédios, como era o caso do Dr. Joaquim Serpa, em Olinda, que veremos adiante. $\bigcirc$ cuidado com enfermos podia estender-se ao cultivo, no quintal, de determinadas ervas medicinais. No primeiro momento foram os padres que fizeram às vezes de médico, combatendo os curandeiros indígenas e suas práticas. Frei Vicente do Salvador explica: "As [folhas] de jurubeba saram as chagas, e as raízes são contrapeçonha. A caroba sara das boubas; o cipó das câmeras. Enfim não há enfermidade contra a qual não haja ervas em esta terra, nem os índios naturais dela têm outra botica ou usam de outras medicinas ${ }^{81}$.

Já Gabriel Soares de Sousa, em seu Tratado, de 1587, também é enfático quando se refere às propriedades terapêuticas de algumas espécies, citando, dentre elas, cabureíba, embaíba, copaíba, caraobuçu, caraobamirim, ubiracica $^{82}$.

Os religiosos, combatendo as práticas místicas dos índios, foram conhecendo as espécies nativas, principalmente seu caráter medicinal. Pela distância do Reino, o custo de trazer mantimentos e o gosto pela aventura, os portugueses começam a descobrir infinitas possibilidades de uso da vegetação local. Os próprios religiosos, pela carência de óleo da Pérsia, começam a utilizar o óleo de caboreíba, que é reconhecido pelo Papa. "Outras árvores há chamadas caboreíbas, que dão o suavíssimo bálsamo com que se fazem as mesmas curas, e o Sumo Pontífice o tem declarado com matéria legítima da santa unção e crisma, e como tal se mistura e sagra com os santos óleos onde falta o da Pérsia." ${ }^{\text {83. }}$.

cultivo de determinadas espécies nativas para fins medicinais foi introduzido nos quintais coloniais. As mesinhas, tão comuns nos discursos do século XVI, deixam transparecer a facilidade de acesso, desde os primeiros anos, a essas ervas. Por outro lado, no Brasil, muitas dessas espécies são adicionadas ao repertório já conhecido e utilizado pelos portugueses no quintal, como é o caso da erva-santa (tabaco). "Petume é a erva a que em Portugal chamam santa; onde há muitas delas pelas hortas e quintais, pelas grandes mostras que tem dado da sua virtude, com a qual se tem feito curas estranhas" 84 .

Poderíamos supor ser natural a manutenção do cultivo doméstico de plantas de utilização tradicional, e ele ocorreu, com efeito, para as que permitiram aclimatação. No entanto, é surpreendente sua convivência com as nativas, modificando ambientes e costumes. Em alguns momentos, houve dupla denominação para a mesma espécie: um nome português e outro indígena ${ }^{85}$.

Boa parte dos cronistas do século XVI - dentre eles Gabriel Soares de Sousa, Frei Cardim e Frei Vicente do Salvador - descrevem minuciosamente a utilização das espécies autóctones recém-adquiridas dos indígenas. Essa prática 
foi incorporada à cultura de tal modo que, mais tarde, no século XIX, os próprios médicos se valiam desses preparados para tratamento dos doentes.

Um bom exemplo disso é Joaquim Jerônimo Serpa. Nascido no Recife, em 1773, cursou medicina na Escola de Cirurgia do Hospital Real de São José, em Lisboa, e regressou ao Brasil como cirurgião-mor do Regimento de Artilharia de Olinda. Foi diretor do Hospital de São Bento em 1814 e, em 1829, ao afastar-se do hospital, deixa seu Receituário para o precioso acervo beneditino. Nele estão impressas todas as receitas médicas produzidas no período.

Por sua dedicação aos estudos da flora, Serpa foi nomeado, em 1834, após concurso, diretor do Jardim Botânico de Olinda ${ }^{86}$, lugar onde lecionou a cadeira de Agricultura e Botânica, e morou até falecer em 1842. O Jardim Botânico, também chamado de Horto de Olinda ${ }^{87}$, foi construído a partir dos fundos dos quintais das casas da rua Nova, aproveitando-se da área e da vegetação já existente. No trabalho do diretor Serpa, interessa-nos a relação que o médico fez entre a prática da cura e o conhecimento das espécies vegetais.

$\bigcirc$ Receituário [Formulário] de Joaquim Serpa indica o quanto de inspiração nativista permeava seu ofício, incluindo em suas receitas muitas espécies utilizadas pelos indígenas e outras que acreditava ter propriedades medicinais. Para Joaquim Serpa, a lpecacuanha, por exemplo, tinha aplicação para quase todos os males. Na receita número 8, de 1823, o médico prescreve "P.a Feciciana e Cypriana. R. e lpecacuanha em pó oitava huma: infunda em água fervente q.do baste, coado com forte expressão, marq.e em duas porçõez. Por este dê outro. \$120"88. Para o historiador Schmalz, que estudou o Receituário [Formulário]:

Esta raiz medicinal é largamente empregada na farmacopédia olindense. Durante três séculos da difusão da flora medicinal no Brasil, constituiu ipecacuanha o remédio universal e gozava aplicação preferencial em muitas doenças. A ipecacuanha era conhecida e utilizada pelo aborígenes para diversos fins medicinais ${ }^{89}$.

Na receita para Alexandrina (número 30, ano 1825), lê-se: "R.e Folhas de carobinha, fumaria e flor de violo adorata aná meia onça: faça cosim. to q. e fique em libra huma: coado marq.e em seiz porçõez"90. Aqui observamos a utilização de folhas de caroba, espécie nativa, indicada em linguagem coloquial, pois já deveria ser muito conhecida da população de Olinda. Além da fórmula, ele trata do modo de fazer o medicamento, ou seja, seu procedimento culinário.

Alguns remédios, como o citado, deveriam ser elaborados a partir de espécies plantadas e colhidas junto à casa, por moradores que tinham conhecimento de suas virtudes medicinais. E faziam um caminho comum, indo do quintal para a panela da cozinha, e da cozinha para o enfermo. Tal prática, provavelmente muito adotada desde os primeiros anos do período colonial, permanece até os dias atuais em algumas localidades, principalmente em cidades de interior onde o acesso a produtos industriais é menor e a influência dos antigos
86. O Jardim Botânico de Olinda, criado por Carta Régia de 19 de novembro de 1798 , foi instalado e inaugurado no dia 21 de junho de 1811."Aos poucos crescia de importância o Jardim Botânico de Olinda - Horto d'El Rei - e ao entregá-lo a seu substituto, o botânico Francês Estevão Paulo Germain já deixava, o Pe.João Ribeiro, grande quantidade de mudas de especiarias e árvores européias, devidamente desenvolvidas e aclimatadas [...] Afora especiarias e madeiras de construção, no Horto já se cultivava árvores frutíferas e plantas exóticas que, pela natureza tropical de nosso clima, aqui se desenvolveram e se aclimataram rapidamente, tornando-se valiosas para a economia da Região.”; cf. Horto de Olinda (1979, p. 19).

87. Segundo Cavalcanti, o Horto teve outros nomes como: "Viveiro de Plantas" ou "Real Viveiro de Plantas" (1811); "Jardim de Especiarias e Plantas Exóticas" (1818); "Estabelecimento de Plantas Exóticas" (1823); "Jardim Nacional e Imperial" (1827); "Jardim das Plantas Exóticas da Cidade de Olinda" (1829); "Horto Botânico" (1835); "Horto D'El Rey" (1915). Ainda segundo o autor, o povo preferia chamar de "Quintas do Rei"; $c$ f. Vanildo Bezerra Cavalcanti (1986, p. 135). De qualquer modo, sua principal função era o estudo, aclimatação e distribuição das espécies trazidas da Europa e de outras colônias.A introdução desses gêneros vinha ocorrendo sistematicamente nos quintais pelas mãos (e necessidades) dos colonos.

88. Ver O Formulário; cf Alfredo Carlos Schmalz (1966, p. 57).

89. Idem, p. 49.

90. Idem, p. 83. 
91. Idem, p. 57.

92.Aspicuelta Navarro, apud Afrânio Peixoto (1988b, p. 285); grifo nosso.

93. Cf. João Baers (2004, p. 31).

94.Aspicuelta Navarro, apud Afrânio Peixoto (1988b, p. 364); grifo nosso. costumes se mantém. Em Olinda, mesmo nos quintais atuais, podemos observar áreas reservadas para esse fim.

Continuando com o Receituário [Formulário], mais adiante aparecem certas curiosidades, como na receita número 11, de 1823: "P.a Fillippa. R. e Olhoz de carangueijoz e marfim pp: aná oitavaz trez, extracto de ópio duro, grãoz seiz, nitro purificado oitavaz duas: tudo em pó se m.e divida em dézeseis porções iguaiz. 22 de 8 br.o de 1823 Serpa J. J." "91. Segundo Schmalz, o marfim pp. é uma árvore, da família das palmeiras, que produz um coco grande com uma substância líquida e transparente, usada como refrigerante. Através das receitas, Serpa indica propriedades terapêuticas não apenas relacionadas às plantas, mas também aos animais autóctones, deixando transparecer uma grande dose de empirismo em suas ações.

Dessa forma podem-se imaginar os procedimentos médicos na colônia portuguesa do século XVI. Em carta do padre Jesuíta Ruy Pereira, da Bahia, aos irmãos da Companhia da Província de Portugal, em 1560, ele relata os procedimentos de cura da época:

E era cousa pera haver piadade vêl-os morrer sem lhes poder dar remédio, porque, posto que trabalhamos todo o possível com sangrias, com mandar pedir muitas laranjas a quem sabíamos que as tinha, e assucar por esses engenhos e posto que nos provinham de tudo com muita caridade, todavia as doenças iam por diante, e tomava-os tão rijos com pontadas e dores, que posto que fosse um mancebo mui robusto, em 4 ou 8 dias the tirava a vida ${ }^{92}$.

Percebe-se que o "médico" da época era o religioso, que trazia da metrópole suas práticas de cura, como as sangrias e frutas estrangeiras, porém sem grandes resultados para as doenças que acometiam a população colonial. Na primeira noite depois da invasão holandesa, Baers comenta: "Ainda nesta mesma noite provamos e saboreamos, com gratidão e prazer, as frutas da terra, como laranjas e limões, para regalo nosso e alívio dos nossos doentes"93. Ele se refere a essas espécies como se fossem nativas, revelando o modo como estavam aclimatadas. No entanto, estariam mais relacionadas ao costume e à tradição portuguesa e, portanto, foram plantadas em abundância nos quintais, como é o caso de laranjeiras, limoeiros, e outros arbustos de frutos cítricos, também conhecidos como árvores de espinhos.

Embora ainda não se possa quantificar nem qualificar com precisão a contribuição dos quintais e cercas conventuais - áreas urbanas cultivadas - para o abastecimento alimentar, sabemos que eram importantes aliados na subsistência da colônia. Como antes citado pelo jesuíta, "Tem muitos legumes e fructas em seu pomar, especialmente a que chamam de bananas, que duram todo o anno e são grande ajuda para a sustentação desta casa"94, ou seja, o cultivo junto às moradias era significativo e, embora não fosse o único meio de abastecimento, fazia parte da estrutura. 
Não poderá ter a sua permanência como espaço servido para assegurar também a permanência de usos? Ao recorrermos à tradição, podemos, por exemplo, valer-nos da memória dos quintais portugueses. Ao percorrer a obra Arquitetura Popular em Portugal (1955-1960), embora vá além do recorte temporal desta investigação, podemos observar as relações entre área edificada, não edificada (quintal) e seus limites (Figuras 23 e 24), em exemplares do Ribatejo:

Não há avareza no terreno que é fácil e vasto. As casas chegam-se à rua e deixam para trás o quintal [...] nos quintais cultivam pequenas hortas que amparam o sustento da família. Nos núcleos compactos o limite da casa para a rua passa-se num plano definido, onde as aberturas aparecem como acidentes. A superfície fechada domina95.

Os arquitetos Nuno Teotônio Pereira, António Pinto de Freitas e Francisco da Silva Dias - responsáveis pelo levantamento das edificações nas províncias da Estremadura, Ribatejo e parte da Beira Litoral - fazem o seguinte relato:

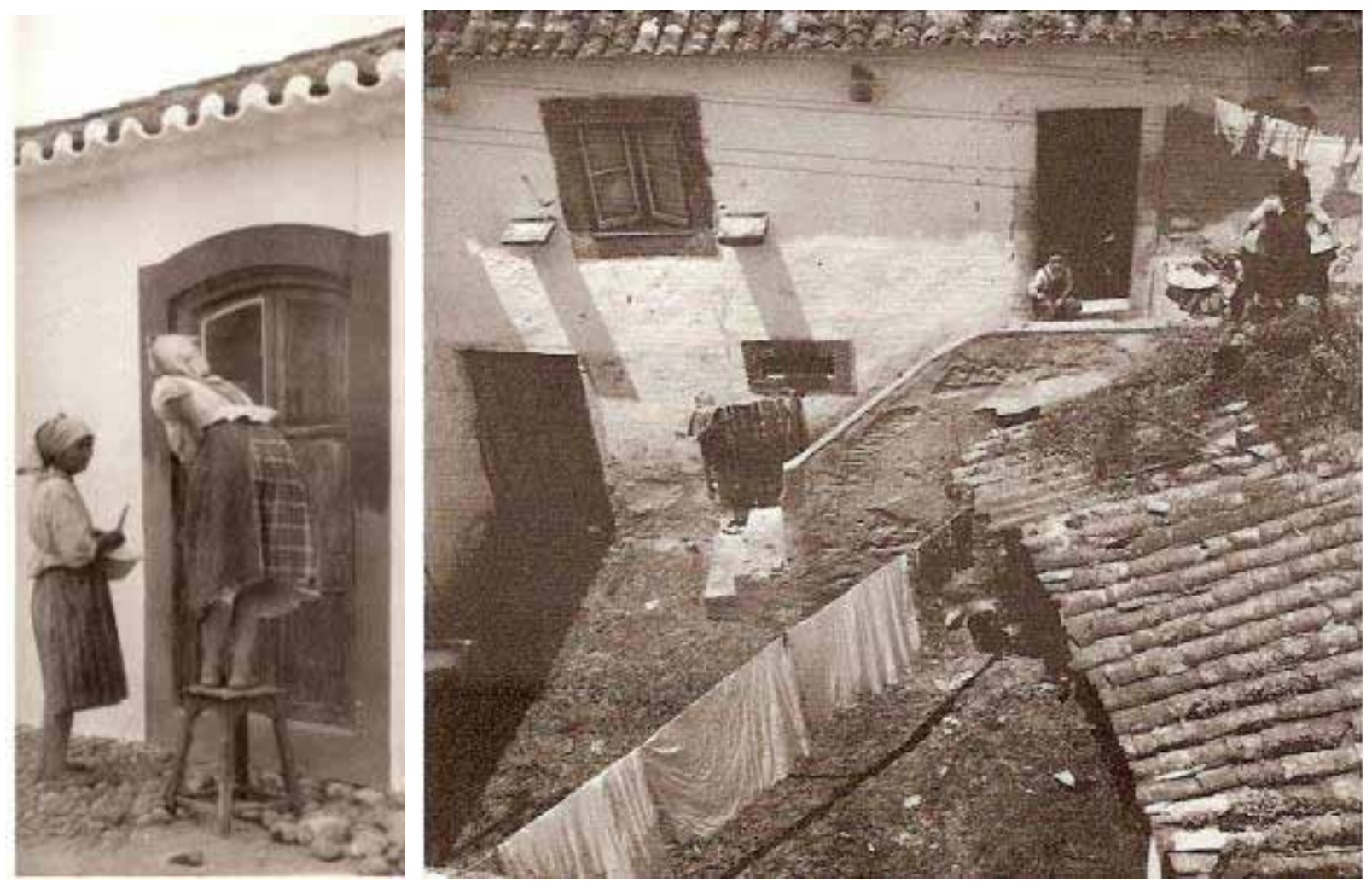

Figuras 23 e 24 - Diferença no tratamento dado à fachada principal (esquerda) e ao quintal (direita) em casa portuguesa na região de Ribatejo (Óbitos) Fonte: Sindicato Nacional dos Arquitectos (1961). 
A casa isola-se da rua. Pode galgá-la e viver sobre ela, mas mantem-se sempre fechada toda a actividade se passa no interior, no quintal, abrigado por trepadeiras ou latadas, verdadeiro prolongamento da habitação, desarrumado, confuso de planos, de escadas e anexos, atafulhado de vasos e gaiolas, entre as casas, ou roubado à rua pelo muro que nos aparece aí verdadeiramente integrado na sua função de elemento de arranjo urbano. $\bigcirc$ dia a dia em relação ao quarteirão, um movimento centrípedo. É que as populações do sul gostam do ar livre, só vivem ou trabalham em casa quando não podem o fazer no quintal. [...] e ao mesmo tempo apreciam a intimidade que a rua lhes nega. As janelas da frente abrem-se em dias de festa 96 .

Na atualidade, buscando os quintais remanescentes em Olinda, podemos observar elementos e modos acima citados no quintal da casa n. 94, na rua do Amparo, entre eles, por exemplo, a espontaneidade e "desordem" na apropriação do espaço (Figura 25). Mas, além da disposição dos equipamentos, constatamos que os moradores conservam aí funções relacionadas à subsistência. Identificamos ainda: a água guardada num reservatório; os utensílios do lar afixados na parede e distribuídos conforme o uso; o varal para as roupas; gaiola; as plantas medicinais; e a construção de anexos, como depósitos, cozinha etc.

Apesar de sua aparente desorganização e de algumas atividades estarem sobrepostas, podemos destacar espaços para fins específicos e delimitados, como a área reservada à pequena horta. Algumas dessas características fazem alusão ao período em que os quintais constituíam um precioso suporte ao abastecimento alimentar.

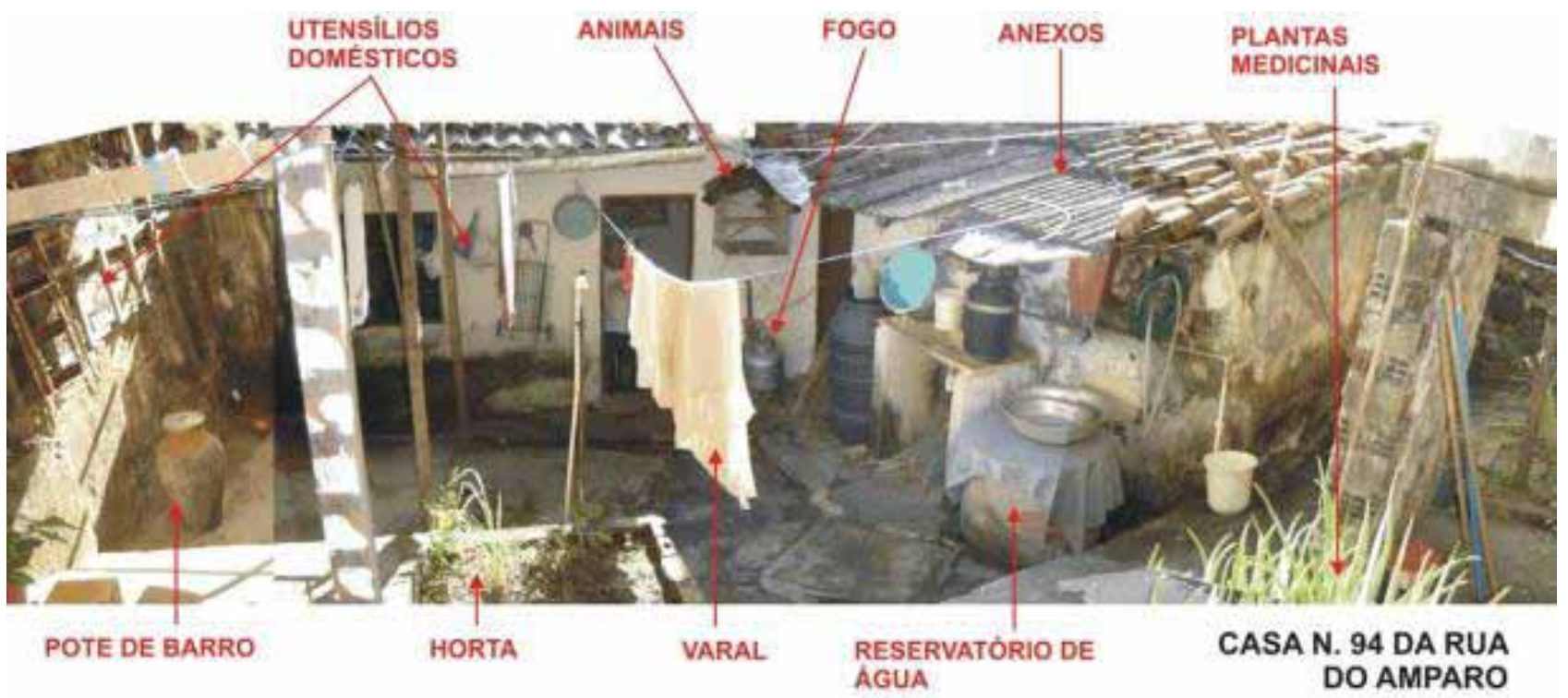

Figura 25 - Identificação da permanência de antigas destinações no quintal. Foto e manipulação: feitas pela autora. 
Outro exemplo, dentre as casas pesquisadas, é a de n. 358, da rua de São João, situada ao lado da Igreja de São João, uma das mais antigas da cidade, e em frente à lgreja do Amparo (Figura 26). A casa de morada inteira tem a fachada principal rebocada, caiada, com beiral alinhado, portas e janelas de madeira com vergas retas, ombreiras, peitoril e soleira de pedra. Nas janelas há conversadeiras, também de pedra.

O tratamento da fachada posterior é mais desleixado, parecendo que ela se molda à necessidade interna, sem se preocupar com regras de composição e aparência. As paredes não estão rebocadas; as janelas e a porta-com vergas, ombreiras e peitoril de madeira - estão desalinhadas. A casa é, em sua maior parte, construída de tijolos e madeira. Embora esteja mal conservada, mantém em sua estrutura características originais. Mesmo as paredes internas das alcovas, que ruíram, mantiveram no piso seu testemunho.

Vale salientar que até hoje, os moradores fizeram relativamente poucas alterações de uso na concepção da antiga casa. Sala da frente para receber, alcovas para dormir, e sala dos fundos para comer e cozinhar. $\bigcirc$ acréscimo foi o banheiro e a pia na sala de jantar, que com certeza não é original (Figura 27).

O piso da casa está situado numa cota bem mais alta que a do piso do quintal, havendo, portanto, uma escadaria para fazer a comunicação com a

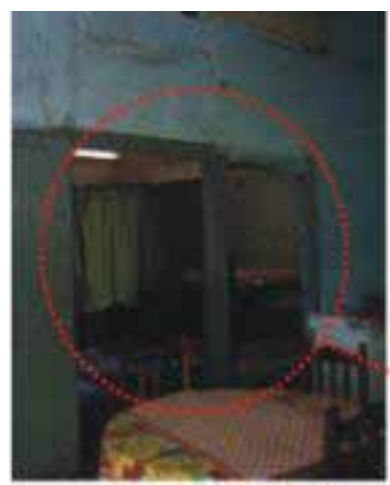

SALA DOS FUNDOS (Jantar e cozinha)

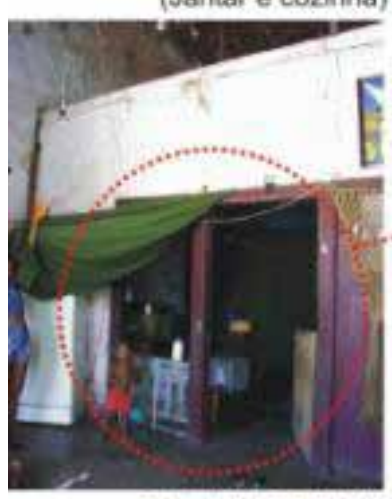

SALA DA FRENTE
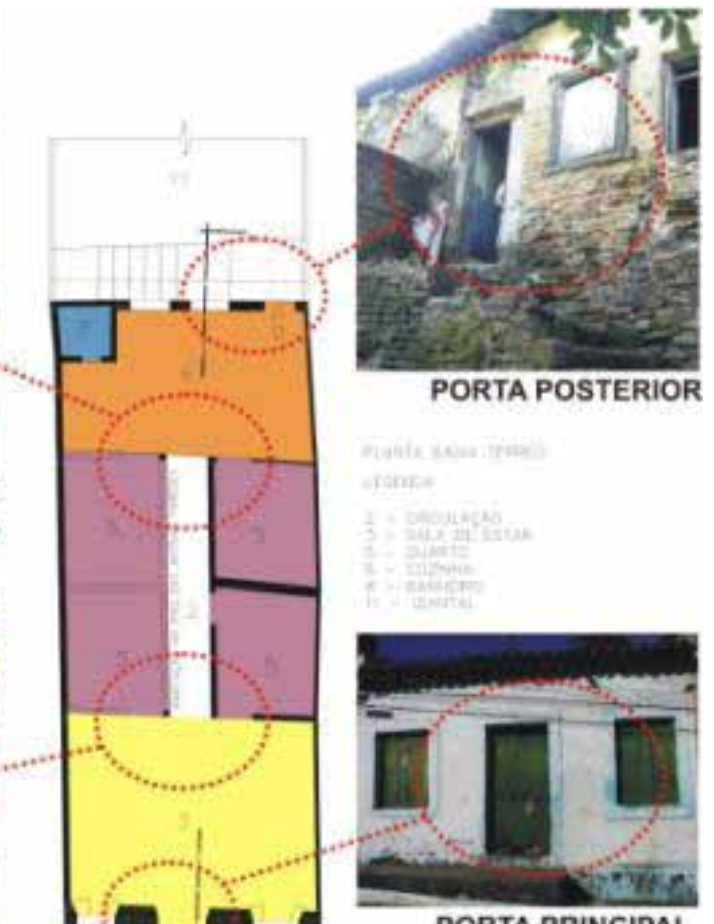

PORTA PRINCIPAL

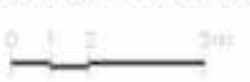

Figura 26 - Indicação dos acessos. Infográfico feito pela autora, baseado em fotos de sua autoria e planta da casa n. 358, da rua de São João, fornecida pela Prefeitura Municipal de Olinda. 


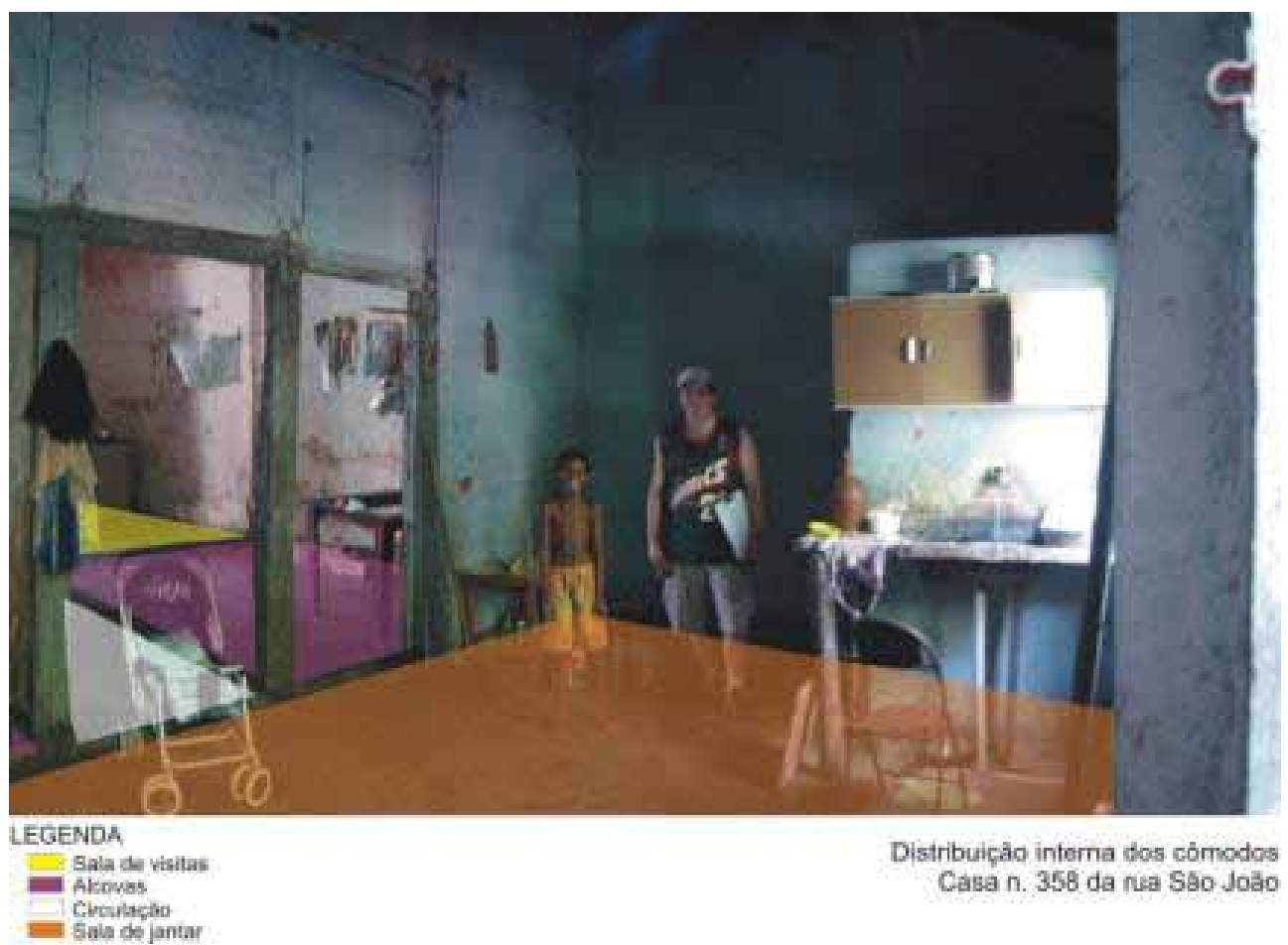

Figura 27 - Casa n. 358 da rua de São João. Foto e manipulação da autora.

97. Cf. Louis Léger Vauthier (1943) $(1975$, p. 85) área posterior. No quintal, o chão é de barro varrido, e a cobertura feita pelas copas das árvores.

Junto à escadaria está uma área destinada para varal de roupas, espécies frutíferas e ornamentais, e o poço de água para o abastecimento da casa. Ao centro, em espaços delimitados, há criação de coelhos e, ao fundo, uma vala por onde escorre a água servida em continuidade com a dos vizinhos, além de um monte de entulhos de antigas construções e o acesso secundário (Figura 28).

A sala posterior ainda é a sala para alimentação da família, diretamente ligada ao quintal e à cozinha que, no período colonial, poderia estar juntada à casa ou isolada no pátio (quintal). $\bigcirc$ acesso à sala posterior era restrito a visitantes, principalmente a cozinha. Em meados do século XIX, o curioso Vauthier adverte:

Quando as portas que dão para o interior da casa se entreabrirem para deixar passar as negras apressadas que acorrem ao chamado do senhor, aproveitai a ocasião, se não receais ser indiscreto, para lançar um olhar furtivo e essa parte dos aposentos, pois não conseguireis ver mais do que isso daquelas misteriosas profundidades, severamente fechadas ao olhar profano ${ }^{97}$. 


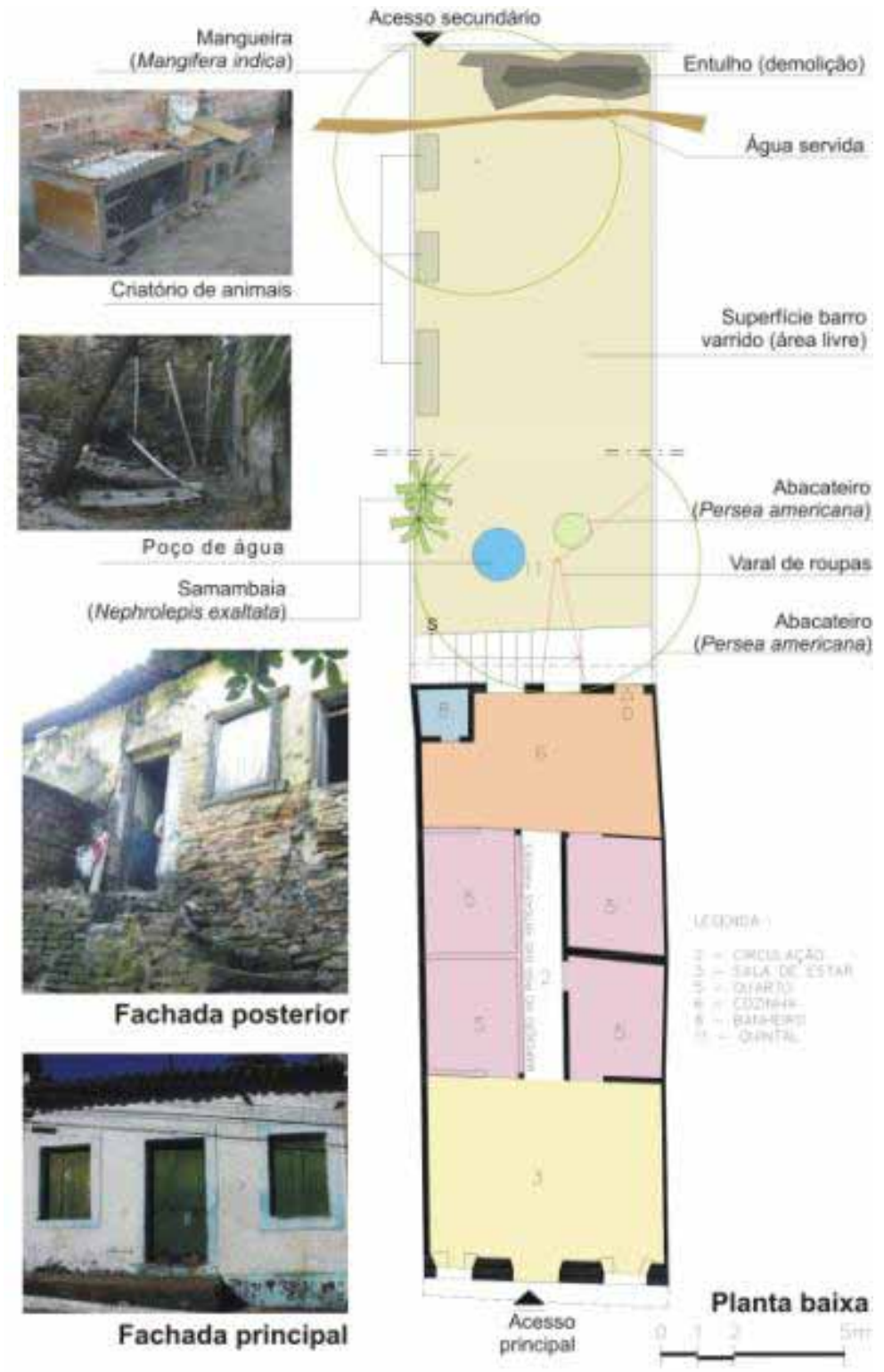

Figura 28 - Concepção da casa. Infográfico elaborado pela autora com fotos de sua autoria, planta baixa da casa da Rua de São João n. 358 fornecida pela Prefeitura Municipal de Olinda e quintal acrescido pela autora.

À experiência de Vauthier, soma-se a questão dos limites cerrados por cercas e muros, indicando não apenas a cozinha, mas também o quintal como lugar de acesso restrito. Em contraponto, a sala de visitas localiza-se junto à rua, onde o tratamento formal da fachada principal, com sua porta e janelas, participa da cerimônia de recepção.

No mundo americano, durante os primeiros séculos de colonização, o espaço de sociabilidade, para a maior parte da população, se concentrava fora das paredes do domicílio, fosse ele a rua ou a igreja, uma vez que os grandes momentos de interação social eram as 
98. Cf. Leila Mezan Algranti (1997, 113).

99.ATAS da Câmara de Salvador (v. VI, p. 194), apud Nestor Goulart Reis Filho (1968, p. 145).

100. Cf. Gilberto Freyre (2005, p. 318). festas religiosas comemoradas com procissões, missas e te-déuns. [...] Nas janelas, tinha-se o cuidado de arrumar vasos de flores e mantilhas, numa interação maior ainda do que a habitual entre a casa e a rua ${ }^{98}$.

O quintal, nesse momento, demonstra ser a antítese da rua e, portanto, da vida social, não apenas por sua localização resguardada atrás da casa, mas pelo próprio desprendimento no aspecto formal. Não há, no quintal, a preocupação com a aparência, pois não tinha a finalidade de aparecer ao público em geral.

Nos relatos da época, a preocupação com a aparência pública é recorrente, evidenciada principalmente no vestuário de passeio e de festas, e na fachada principal, que passa durante muito tempo a deter a atenção, inclusive das Câmaras. "Por ocasião das festas religiosas é que se determinava aos moradores que capinassem e limpassem as ruas e tapassem os buracos e valos abertos pelas enxurradas, em frente às suas casas, que por sua vez, deviam ser caiadas." "99 Em relação à apresentação pública - não apenas das ruas, das fachadas das casas, mas também, do vestuário -, Gilberto Freyre remarca uma certa contradição: "Mas toda essa opulência de roupa e criadagem a rua à custa de verdadeiro ascetismo dentro de casa. Esse brilho de vestuário à custa de verdadeira indigência na alimentação. Da falta absoluta de conforto doméstico. Ou então à custa de dívidas" 100 . Alguns viajantes chegam mesmo a afirmar que, quando em casa, era difícil reconhecer as senhoras que iam para a igreja no domingo, devido ao demasiado descaso que apresentavam à sua aparência doméstica. Segundo eles, não era raro encontrar homens de ceroulas, mulheres de camisão e crianças nuas, mas, deste modo, nunca ultrapassavam os limites da esfera domiciliar. E mesmo na casa, não se entrava na sala de visitas assim, pois era o lugar de recepção. Nesta composição, o quintal, espaço mais informal e recuado do acesso principal, passava a ser quase inacessível a visitas cerimoniosas.

Ainda hoje, é possível perceber uma grande distinção entre a vida pública e a doméstica, muito embora as escalas e contextos sejam diferentes. Os espaços urbanos, principalmente os sítios históricos, refletem essa mudança comportamental e as transformações ao longo do tempo, contendo, em suas rugas, vestígios de uma trajetória.

Voltemos à casa n. 358 da rua São João. Já referida, a casa é uma morada de família simples e acolhedora. É uma das poucas de que há registro fotográfico do quintal na Prefeitura, em 1999, quando houve o levantamento cadastral do sítio histórico (Figura 29). Tal fato permite uma análise comparativa das mudanças ocorridas nesse espaço durante os 7 últimos anos.

Na foto de 1999, o quintal era mais rico, possuía mais equipamentos e criação de animais mais diversificada. Na primeira imagem, podemos perceber patos e galinhas criados soltos. A água servida escorre pelo meio do quintal até a vala ao fundo - isto permanece. Nota-se que o quintal não é apenas uma área de plantio: o chão, na maior parte, é de barro varrido, e essa limpeza expressa 


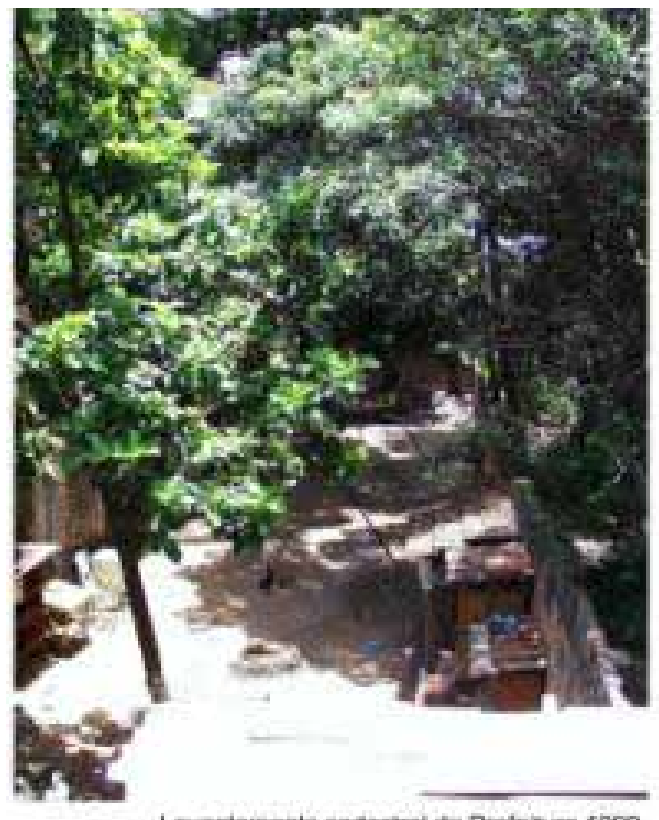

Levantartento casastral da Prefentura 1999

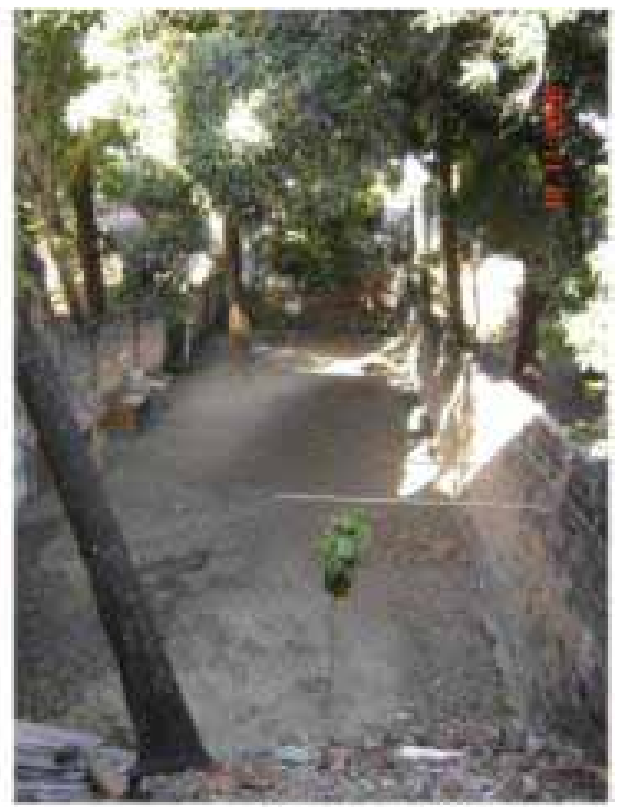

Fota feta em 2006 pela autora

Figura 29 - Comparação entre dois períodos da casa n. 358 da rua de São João.

a ordem que o submete. Os espaços possuem funções específicas, mas bem mais flexíveis e dinâmicas que a casa.

Esta casa e a sucessão das fotos mostram o empobrecimento da família que está refletida, entre outras coisas, na diminuição de sua mobília interna e da variedade de atividades no quintal. Na maior parte das casas visitadas, pode-se observar uma perda gradativa das atividades tradicionais que formavam o espaço, pela substituição, proporcionada pela vida moderna, por novas fontes de abastecimento e serviços. Outra questão importante é a diminuição do interesse pela transmissão dos valores. Poucos moradores, e antigos, detêm informações preciosas sobre a utilização de espécies vegetais, que cada vez mais vêm sendo perdidas na memória de outros tempos. Esse panorama apresenta desafios para as estratégias de conservação patrimonial.

Considerações finais

Os quintais de Olinda não podem ser compreendidos fora do contexto espacial e temporal em que foram concebidos, estando diretamente vinculados à proposta inicial da Vila. Proposta esta nascida da intenção do donatário, mas, acima de tudo, de sua experiência acumulada, seja nas outras colônias portuguesas, seja em sua memória urbana. 
A concepção urbana surge então condicionada por uma série de questões que norteiam a apropriação do território. Isso permite uma relação significativa entre a experiência urbana e as características do sítio, expondo assim uma determinada racionalidade na ação urbana. Particularidades quanto à declividade do terreno, aos cursos de água, à vegetação nativa complementam a proposta colonizadora, fazendo-se explícita na Carta Foral e no espaço urbano. Tais fatores repercutem no sistema defensivo, na circulação, no comércio, no abastecimento de água e de produtos, no autoabastecimento, nas crenças, na apropriação da natureza, e, logicamente, nos quintais.

Ao confrontarmos as iconografias do século XVI e XVII e a foto aérea do sitio histórico podemos perceber que a cidade ainda guarda muitos traços originais da antiga Vila (Figura 30), representados na permanência do traçado, e também dos edifícios religiosos, da área do antigo Horto del'Rey (atual Sítio do Manguinho), e, principalmente, dos quintais e cercas que ainda compreendem boa parte do território.

Nos quintais atuais podemos perceber que ainda permanecem várias atividades descritas para o contexto colonial, como o cultivo de determinadas

Figura 30 - Vista aérea de Olinda com a demarcação do antigo traçado e dos principais edifícios, assim como a área do Horto e do Varadouro. Fonte da foto: Prefeitura Municipal de Olinda. Infográfico elaborado pela autora.

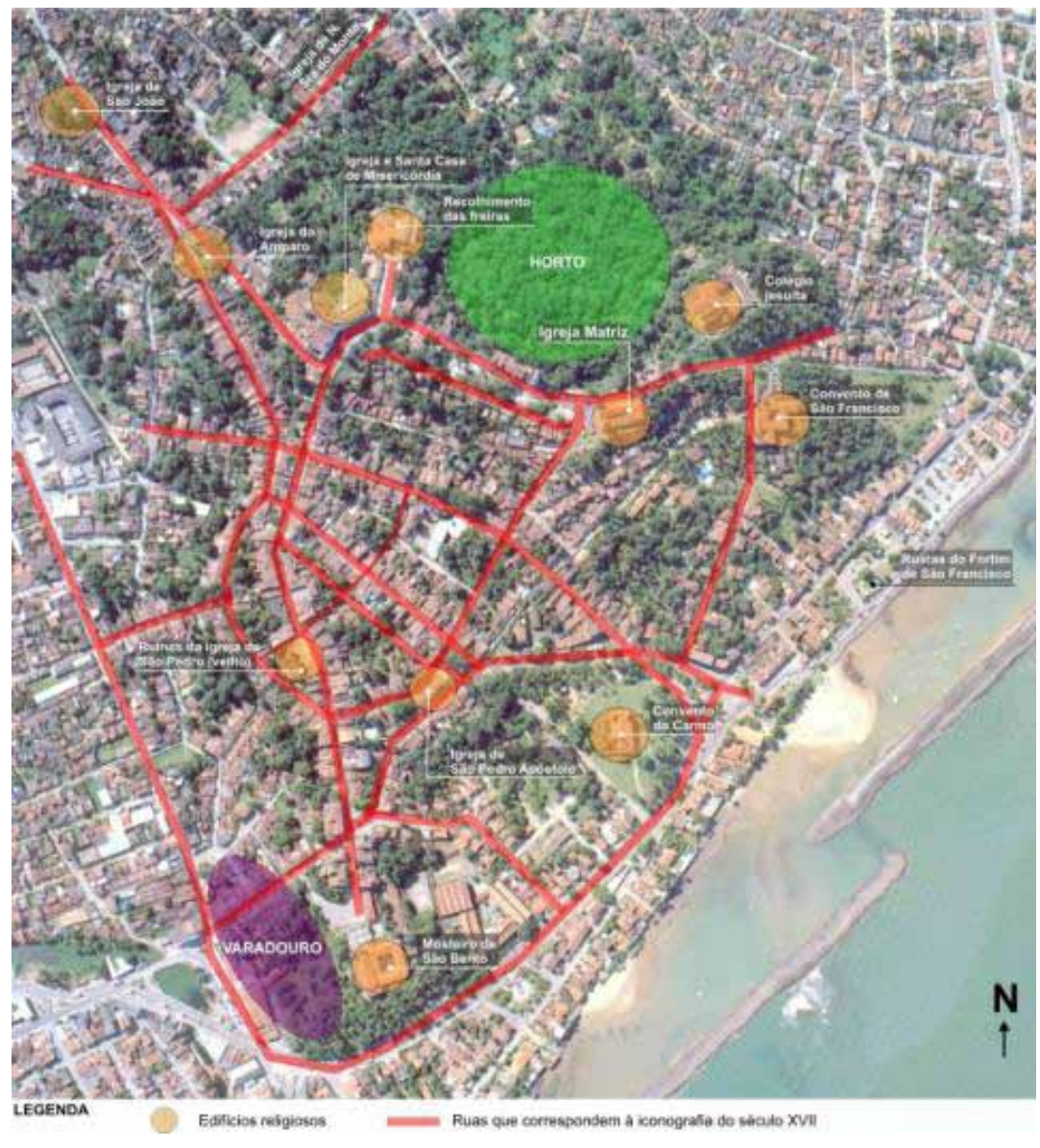


espécies vegetais e animais, a lavagem de roupas, o depósito entulho etc. Contudo, novas demandas colocadas pela vida moderna, como a necessidade de garagem, de ampliação de cômodos, por exemplo, têm retalhado os quintais e ameaçado a continuidade de sua existência.

Oestudo da formação dos quintais nos permite, portanto, compreender a importância desses espaços enquanto suporte de nossa memória coletiva, enquanto abrigo de práticas tradicionais, mantenedores da biodiversidade e de uma proposta eficiente de apropriação do território. Cabe acrescentar que a investigação sobre a gênese dos quintais provoca uma reflexão consistente sobre a experiência urbana brasileira.

\section{REFERÊNCIAS BILIOGRÁFICAS}

ALGRANTI, Leila Mezan. Famílias e vida doméstica. In: SOUZA, Laura de Mello e (Org.). História da vida privada no Brasil: cotidiano e vida privada na América Portuguesa, 1. São Paulo: Companhia das Letras, 1997.

ANDRADE,Amélia Aguiar. Horizontes urbanos medievais. Lisboa: Horizonte, 2003.

SINDICATO NACIONAL DOS ARQUITECTOS. Arquitectura popular em Portugal, 1. Lisboa: Gráfica São Gonçalo, 1961.

BAERS, João. Olinda Conquistada.Trad. Alfredo de Carvalho; Org. Leonardo Dantas Silva. Recife: Companhia Editora de Pernambuco, 2004.

BARLÉU, Gaspar [Caspar van Baerle]. História dos fatos recentemente praticados durante oito anos no Brasil (1648). Pref. e notas Mário G. Ferri. Belo Horizonte: Itatiaia; São Paulo: Edusp, 1974.

BARREIROS, Maria Helena (Coord.). Lisboa: conbecer, pensar, fazer cidade. Lisboa: Câmara Municipal de Lisboa - Departamento de Informação Urbana, 2001.

BLUTEAU, Raphael. Vocabulário portuguez, e latino, aulico, anatomico, architectonico, bellico, botanico... Coimbra: Real Collegio das Artes da Companhia de Jesu, 1712. $10 \mathrm{v}$.

BOOGART, Ernst et al. Viver e morrer no Brasil bolandês. Org. Marcos Galindo. Recife: Massangana, 2005.

BUENO, Beatriz P. Siqueira.A iconografia dos engenheiros militares no século XVIII: instrumentos de conhecimento e controlo do território. In: CARITA, Hélder;ARAÚJO, Renata (Coord.). Coletânea de estudos: universo urbanístico português 1415-1822. Lisboa: CNCDP, 1998.

Decifrando mapas: sobre o conceito de "território" e suas vinculações com a cartografia. Anais do Museu Paulista, São Paulo, v. 12, n. 1, p. 193-234, jan.-dez. 2004.

CALADO, Frei Manuel. O valoroso Lucideno e o triunfo da liberdade, 1.4 ed. Pref. José Antônio Gonsalves de Mello. Recife: Fundarpe-Diretoria de Assuntos Culturais, 1985.

CARDIM, Fernão. Tratados de terra e gente do Brasil. [Introdução de Rodolfo Garcia]. Belo Horizonte: Itatiaia; São Paulo: Edusp, 1980. 
CARITA, Helder. Lisboa manuelina e a formação de modelos urbanísticos da época moderna (1495-1521). Lisboa: Horizonte, 1999.

CASAL, Manuel Aires de. Corografia brasílica ou relação histórico-geográfica do Reino do Brasil [pelo] Pe. Manuel Aires de Casal. Belo Horizonte: Itatiaia; São Paulo: Edusp, 1976.

CASCUDO, Luís da Câmara. História da alimentação no Brasil. São Paulo: Global, 2004.

CAVALCANTI, Vanildo Bezerra. Olinda do Salvador do Mundo: biografia da cidade. Recife:ASA, 1986.

COSTA, Francisco Augusto Pereira da.Anais Pernambucanos, 1, 2 e 6. Recife: Fundarpe-Diretoria de Assuntos Culturais, 1983.

DENUNCIAÇÕES de Pernambuco, 1593-1595. Primeira Visitação do Santo Officio ás partes do Brasil. Pelo licenciado Heitor Furtado de Mendoça. Capellão Fidalgo Del Rey nosso Senhor e do Seu Desembargo, Deputado do Santo Officio. São Paulo: Paulo Prado, 1929 [Lisboa,Arquivo Nacional da Torre do Tombo, Cartório da Inquisição, Códice 130].

FERREIRA,Aurélio Buarque de Holanda. Novo dicionário Aurélio da língua portuguesa. 2. ed rev. ampl. Rio de Janeiro: Nova Fronteira, 1986.

FORTES, Manoel de Azevedo. Tratado do modo o mais fácil e o mais exacto de fazer as cartas geographicas. Lisboa: Pascoal da Sylva, 1722.

O engenheiro portuguez: dividido em dous tratados... Lisboa Occidental: Manoel Fernandes da Costa, 1728-1729. 2v.

FREYRE, Gilberto. Casa grande E senzala: formação da família sob o regime da economia patriarcal. 4. ed. São Paulo: Global, 2005.

GALINDO, Marcos; MENEZES, José Luís Mota. Desenbos da terra. Atlas Vingboons. Recife: Bandepe, 2003.

GINZBURG, Carlo. Mitos e emblemas: sinais, morfologia e história. São Paulo: Companhia das Letras, 1990.

HORTO DE OLINDA. Plano Diretor do Horto de Olinda. Governo do Estado de Pernambuco-Fidem. Recife, set. 1979.

LISBOA, Frei Christovão de. Historia dos animaes e arvores do/ Maranhão. Pelo muito Reverendo Padre Fr. Chis/tovão de Lisboa Calificador do Santo/ Officio, e fundador da custodia do/Maranbão da Recolecção de/Santo Antonio de/Lisboa/.Anno/. [Escrita, presumivelmente, entre os anos de 1625 a 1631] Códice 1660. In: PROJETO RESGATE. Brasília: Ministério da Cultura; Lisboa:Arquivo Histórico Ultramarino, 1995.

MARX, Murillo. Cidade no Brasil terra de quem? São Paulo: Edusp; Nobel, 1991.

MELLO,Antônio Gonsalves de. Cartografia holandesa do Recife. Estudo dos principais mapas da cidade, do período 1631-1648. Recife: PHNG/Iphan/MEC, 1976.

MENEZES, José Luís Mota. Olinda: evolução urbana. In: CARITA, Hélder;ARAÚJO, Renata (Coord.). Coletânea de estudos: universo urbanístico português, 1415-1822. Lisboa: CNCDP, 1998. 
NIEUHOF, Joan. Memorável viagem marítima e terrestre ao Brasil. Trad. Moacir N. Vasconcelos; introd. e notas José Honório Rodrigues. Belo Horizonte: Itatiaia; São Paulo: Edusp, 1981 [cf.edição holandesa de 1682].

NOVAIS, Fernando A. Condições da privacidade na colônia. In: SOUZA, Laura de Mello e (Org.). História da vida privada no Brasil: cotidiano e vida privada na América Portuguesa, 1. São Paulo: Companhia das Letras, 1997.

PEIXOTO, Afrânio (Org.). Cartas Jesuíticas 1. Manoel da Nóbrega, Cartas do Brasil, 1549-1560. Belo Horizonte: Itatiaia; São Paulo: Edusp, 1988a.

Cartas Jesuíticas 2. Aspicuelta Navarro e outros, Cartas Avulsas, 1550-1568. Belo Horizonte: Itatiaia; São Paulo: Edusp, 1988b.

PROJETO Foral. Relatório II. Olinda: Prefeitura de Olinda-Secretaria do Patrimônio, 2000.

REIS FILHO, Nestor Goulart. Evolução Urbana no Brasil. São Paulo: Edusp, 1968.

Imagens de vilas e cidades do Brasil colonial. São Paulo: Imprensa Oficial do Estado; Fapesp, 2000.

São Paulo: vila, cidade, metrópole. São Paulo:Takano, 2004.

RYBCZYNSKY,Wiltold. Casa: pequena história de uma ideia. Rio de Janeiro: Record, 2002.

SALVADOR, Frei Vicente do. História do Brasil 1500 - 1627. $7^{\mathrm{a}}$ Ed. Belo Horizonte: Ed. Itatiaia; São Paulo: Ed. da Universidade de São Paulo, 1982.

SCHMALZ, Alfredo Carlos. Receituário de Joaquim Jerônimo Serpa. Hospital de São Bento de Olinda, 1823-1829. Recife:Arquivo Público Estadual-Imprensa Oficial, 1966.

SOUSA, Gabriel Soares de. Tratado descritivo do Brasil em 1578.4 ed. São Paulo: Nacional; Edusp, 1971.

VARNHAGEN, Francisco Adolfo de. História geral do Brasil: antes da sua separação e independência de Portugal. São Paulo: Melhoramentos, 1978.

VAUTHIER, Louis Léger. Casas de Residência no Brasil. In: FAU-USP; MEC-IPHAN. Textos escolbidos da Revista do Instituto do Patrimônio Histórico e Artístico Nacional:Arquitetura Civil I. São Paulo: FAU-USP, 1975.

\section{SITE VISITADO}

<http://www.olinda.pe.gov.br/portal/olinda_em_dados.php >. Site oficial da Prefeitura Municipal de Olinda.Acessado 20.06.2012..

Artigo apresentado em 1/2011. Aprovado em 12/201 1. 